\title{
EVOLVING ROLE OF THE COURTS: \\ CONSTITUTIONAL REVIEW OF LEGISLATION \\ UNDER THE \\ NEW ZEALAND BILL OF RIGHTS ACT 1990
}

By

\section{Charlotte Connell}

\author{
A dissertation \\ submitted to the Victoria University of Wellington \\ in partial fulfilment of the requirements for the degree of \\ Master of Laws
}

VICTORIA UNIVERSITY OF WELLINGTON

2010 


\section{CONTENTS}

A NeW ZEALAND's CONSTITUTION

1 Orthodox view of New Zealand's constitution.................................................................. 7

2 Constitutional realist view of New Zealand's constitution .................................................11

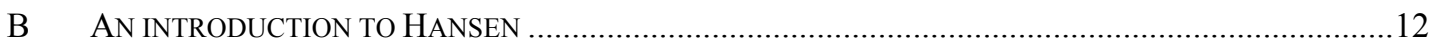

C LEGITIMACY OF CONSTITUTIONAL REVIEW OF LEGISLATION................................................14

II LEGAL AUTHORITY FOR CONSTITUTIONAL REVIEW .................................................16

A MODELS OF LEGAL AUTHORITY FOR CONSTITUTIONAL REVIEW .............................................16

B LEGAL AUTHORITY FOR REVIEW OF LEGISLATION UNDER THE BILL OF RIGHTS ACT ...................18

1 Section 5 of the Bill of Rights Act targeted at Legislature and Executive ............................20

2 Section 4 of the Bill of Rights Act precludes review of legislation .......................................21

3 Current approach to section 5 of the Bill of Rights Act.......................................................23

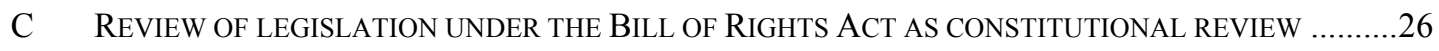

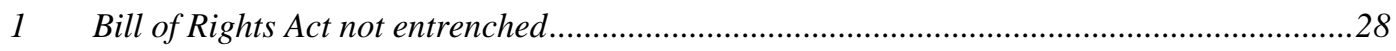

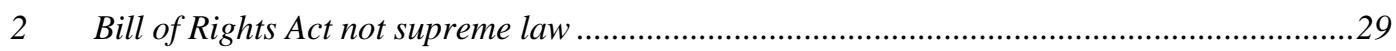

3 Preservation of legislative supremacy: section 4 of the Bill of Rights Act...........................30

D CONSTITUtional CHARACTER OF THE BILl OF RightS ACT IN PRACTICE.................................31

III PERFORMANCE OF CONSTITUTIONAL REVIEW .......................................................35

A Purposive APPROACH to InTERPRETATION AND THE BiLl OF Rights ACT ..............................37

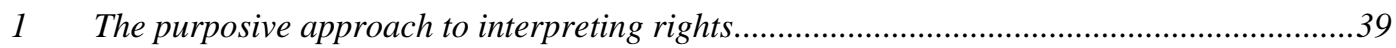

2 Purposive approach to interpreting the legislative provision on the right............................44

3 Assessing the effect of the legislative provision on the right .................................................46

B CHALLENGES FOR THE PURPOSIVE APPROACH IN RELATION TO THE BILL OF RIGHTS ACT ...........50

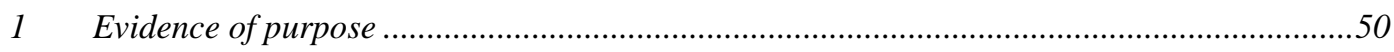

2 Judicial discussion of the nature of a right is essential .........................................................51

3 Altering the application of the Bill of Rights Act to a right .................................................52

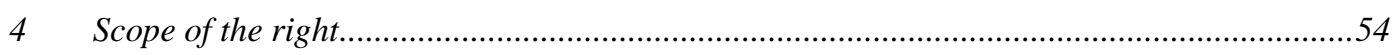

$5 \quad$ Interpretation and section 6 of the Bill of Rights Act ........................................................55

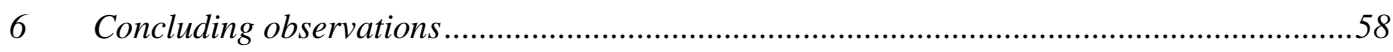

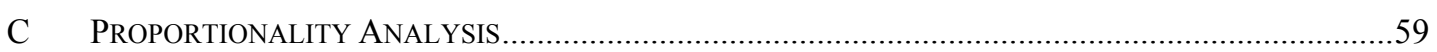

1 Assessing the value and importance of an objective ........................................................64

2 Judicial analysis of the policy options................................................................................66

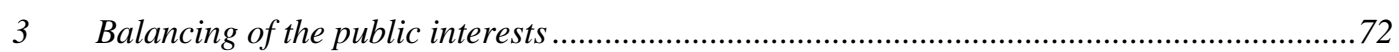

D PRUDENT USE OF JUDICIAL DEFERENCE AND RESTRAINT ........................................................78

$1 \quad$ Principle of institutional capacity and judicial deference .....................................................8

2 Principle of legitimacy and judicial restraint.....................................................................83

3 Proportionality test, intensity of review, and deference …...............................................84

E CONSTITUTIONAL REVIEW AND DECLARATIONS OF INCONSISTENCY .........................................86 


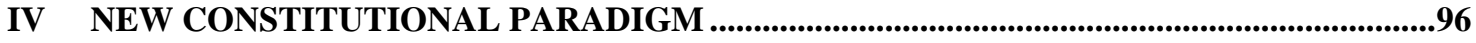

$1 \quad$ Conceptual weakness with the orthodox view ................................................................96

2 Alternative paradigms for the relationship between Parliament and the courts ...................99

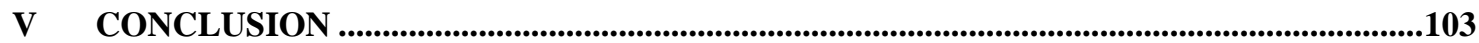

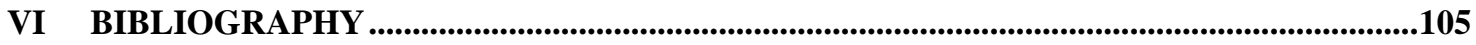

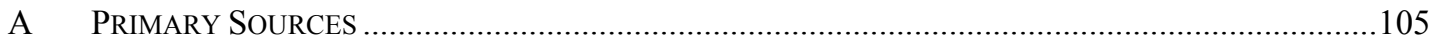

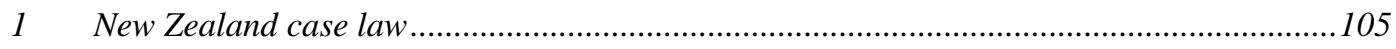

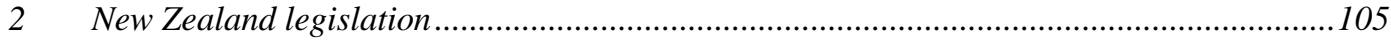

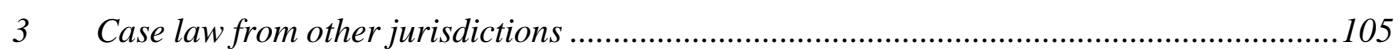

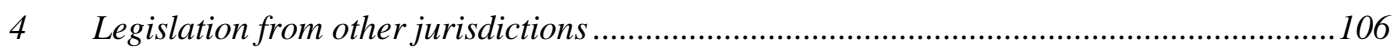

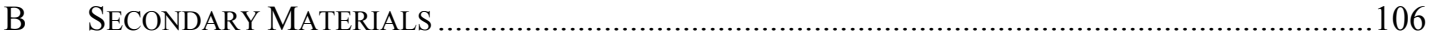

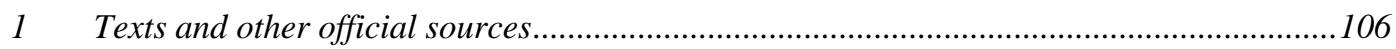

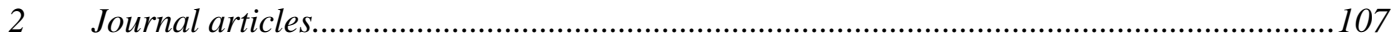




\begin{abstract}
The constitutional landscape in New Zealand has undergone significant change over the last 2035 years to improve the transparency and accountability of decision-making in the three branches of government. While most of these changes are a direct result of legislation, the constitutional role of the court has also been evolving and has seen the development of judicial review of the substance of the law for consistency with the New Zealand constitution. The orthodox view of the constitution is heavily critical of judicial, or constitutional, review of legislation by the courts and considers it to be an illegitimate encroachment on the domain of Parliament.

This paper explores the legitimacy of constitutional review of legislation by the courts, specifically constitutional review of legislation under the New Zealand Bill of Rights Act 1990 (the Bill of Rights Act). To be legitimate, constitutional review by the courts must have both legal authority and be performed consistently with the constitution. This paper observes that $\mathrm{s} 5$ of the Bill of Rights Act has been employed by the courts, without interference from Parliament, to review legislation for consistency with that Act and that the courts use the purposive approach to interpretation and the proportionality analysis to perform such review consistently with the constitution. Finally, the paper explores whether the developing jurisdiction of constitutional review necessitates a new paradigm to define the constitutional relationship between the courts and Parliament because the orthodox view of New Zealand's constitution is no longer supportable as the definitive position.
\end{abstract}

\title{
Word length
}

The text of this paper (excluding abstract, table of contents, footnotes, and bibliography) comprises approximately 35,650 words.

\section{Subjects and Topics}

Constitutional Review of Legislation

New Zealand Bill of Rights Act 1990

Declarations of inconsistency

Judicial deference and restraint to Parliament

Human Rights 


\section{INTRODUCTION}

New Zealand's constitution is a creature of "pragmatic evolution", and it is no surprise that the New Zealand constitution has evolved to accommodate the courts to performing constitutional review of legislation under the New Zealand Bill of Rights Act 1990 (the Bill of Rights Act). ${ }^{2}$ Constitutional review under the Bill of Rights Act is legitimate not only by virtue of the legal authority for it conferred by s 5 of the Bill of Rights Act but also because the courts perform it consistently with the New Zealand constitution. Constitutional review under the Bill of Rights Act is holding its ground despite the challenges it presents to the orthodox view of the constitution suggesting it is timely for a new paradigm to describe the constitutional relationship between the courts and Parliament is necessary.

The orthodox view of the relationship between Parliament and the courts places Parliament as the ultimate lawmaker and restricts the courts' role to that of interpreting and applying the law specifically excluding the ability of the courts to examine the substance of the law. However, changes to New Zealand's constitutional landscape over the last 35 years make the continuation of the orthodox position untenable. Many of these changes have occurred as a result of legislative change such as the establishment of the Waitangi Tribunal by the Treaty of Waitangi Act 1975, the founding of ombudsmen under the Ombudsmen Act 1975, the introduction of official information requests under the Official Information Act 1982, the enactment of the Bill of Rights Act, a new electoral system of mixed member proportional enacted through the Electoral Act 1993, and the establishment of the Supreme Court of New Zealand by the Supreme Court Act 2003. These legislative changes have introduced greater transparency and accountability mechanisms for ensuring the good governance of New Zealand.

Constitutional change has occurred not only in the executive and legislative branches of the government; the constitutional role of the courts has also had to evolve over the last 35 years to accommodate these changes, especially in the field of judicial review. In 1998, Philip Joseph identified three new grounds of judicial review for claims under: the Treaty of Waitangi, the New Zealand Bill of Rights Act 1990, and

\footnotetext{
${ }^{1}$ Constitutional Arrangements Committee Inquiry to Review New Zealand's Existing Constitutional Arrangements: Report of the Constitutional Arrangements Committee (2005) AJHR I.24A [Inquiry to Review New Zealand's Existing Constitutional Arrangements].

${ }^{2}$ For the purposes of this paper the New Zealand Bill of Rights Act 1990 is referred to as the "Bill of Rights Act"; however, in some quotes it may be referred to as "BORA" or a variation.
} 
international human rights instruments to which New Zealand was a party. ${ }^{3}$ Joseph characterises this form of judicial review as "constitutional review" because it involves substantive review of a decision and the grounds are inherently constitutional. ${ }^{4}$ Furthermore, Joseph identifies the proportionality test as the touchstone of judicial analysis of constitutional review. ${ }^{5}$ In relation to the Bill of Rights Act, Joseph observes that the Act: "mandates constitutional adjudication. In applying s 5 (the "justified limitations" section), the Court of Appeal has identified the methodology essentially of constitutional review."6 Constitutional review challenges orthodox views of the relationship between Parliament and the courts because it invites the courts to examine the substance of the law. While Joseph's article focused on administrative decisionmaking $^{7}$ there are now clear examples of the expansion of constitutional review into legislation for consistency with the Bill of Rights Act. ${ }^{8}$ Joseph discussion of constitutional review is used to guide the analysis of constitutional review of legislation in this paper.

While this paper does not seek to answer the expansive question of "in what direction should New Zealand's constitution be heading?" it intends to contribute to this broader discussion by exploring the evolving constitutional role of the courts in relation to constitutional review of legislation under the Bill of Rights Act. To be legitimate, constitutional review by the courts must have both legal authority and be performed consistently with New Zealand's constitution. This paper establishes that constitutional review of legislation under the Bill of Rights Act is not only legitimate, but also fast becoming an essential part of our constitutional culture. For example, both the legislative and executive branches of government acknowledge the growing role of constitutional review of legislation by the courts and have not sought to curtail it through corrective legislation but instead are employing the courts' analytical methods to inform policy and law-making. To this end, the developing jurisdiction of constitutional review necessitates a new paradigm to define the constitutional relationship between the courts and Parliament in New Zealand because the orthodox view is no longer supportable as the definitive position.

\footnotetext{
${ }^{3}$ Philip Joseph "Constitutional Review Now" [1998] NZ Law Review 85; see also Philip Joseph Constitutional and Administrative Law in New Zealand (3 ${ }^{\text {rd }}$ ed, Brookers, Wellington, 2007) at 21.11 ["Constitutional and Administrative Law”].

${ }^{4}$ Joseph "Constitutional Review Now", above n 3, at 90.

${ }^{5}$ Joseph "Constitutional Review Now", above n 3, at 91.

${ }^{6}$ Joseph "Constitutional Review Now", above n 3, at 125.

${ }^{7}$ Joseph "Constitutional Review Now", above n 3, at 126.

${ }^{8}$ See Hansen $v R$ [2007] NZSC 7 [Hansen] and $R$ v Poumako [2000] 2 NZLR 695 (CA).
} 
Before examining the changing constitutional role of the courts in light of constitutional review under the Bill of Rights Act it is helpful to set out some context about New Zealand's constitution, the orthodox view of the relationship between Parliament and the courts, the Supreme Court's decision in Hansen $v R^{9}$ (Hansen) which will be used as a case study for this paper and constitutional review.

\section{A New Zealand's constitution}

The nature of New Zealand's constitution is pertinent because it is the benchmark against which the activities of the courts, in performing constitutional review, are measured. In New Zealand, the constitution is not found in a single written legal document, like that of the United States of America. Instead, as described by the Constitutional Arrangements Committee, New Zealand's constitution is "partly written and wholly uncodified". ${ }^{10}$ New Zealand constitution is a network of legislation, case law, common law, and conventions that operate together to govern New Zealand. Joseph, in the seminal text on constitutional law in New Zealand: Constitutional and Administrative Law in New Zealand, describes constitutional law as being "concerned with the history, structure, and functioning of central government carried on in accordance with the law, constitutional convention and the expectations of liberal democratic government." 11

\section{Orthodox view of New Zealand's constitution}

The orthodox view of New Zealand's constitution is heavily based on the doctrine of parliamentary sovereignty. The authoritative description of the doctrine of parliamentary sovereignty is attributed to Dicey who describes it as: ${ }^{12}$

... Parliament ... [having], under the English constitution, the right to make or unmake any law whatever; and, further, that no person or body is recognised by the law of England as having a right to override or set aside the legislation.

While Dicey and his peers, such as Thomas Hobbes of Magdalen and William Blackstone, were deciphering the doctrine of parliamentary sovereignty in the late $19^{\text {th }}$

\footnotetext{
${ }^{9}$ Hansen, above $\mathrm{n} 8$.

${ }^{10}$ Constitutional Arrangements Committee Inquiry to review New Zealand's existing constitutional arrangements, above $\mathrm{n} 1$, at 84 .

${ }^{11}$ Joseph Constitutional and Administrative Law, above $\mathrm{n} 3$, at 1.

${ }^{12}$ A V Dicey An introduction to the study of the Law of the Constitution ( $8^{\text {th }}$ ed, Macmillan, United Kingdom, 1996) at 38.
} 
century, the seeds of this doctrine are perceivable in the Bill of Rights $1688 .^{13}$ The Bill of Rights 1688 is the legal reflection of an historical and political event: the English Revolution in 1688 (also referred to as the "Glorious Revolution") which is said to have: "swept aside any limitation on parliamentary power" placing the substantial power in the hands of Parliament rather than the Sovereign. ${ }^{14}$

The Bill of Rights 1688 remains part of the laws of New Zealand by virtue of $\mathrm{s}$ 3(1) and sch 1 of the Imperial Laws Application Act 1988. Article 1 (Dispensing power) of the Bill of Rights 1688, which states that: "the pretended power of suspending of laws or the execution of laws by Regall Authority without the consent of Parlyament is illegall", places the power to suspend or execute laws in the hands of Parliament. Similarly, art 13 (Frequent Parlyaments) of the Bill of Rights 1688 states that: "[a]nd for the redresse of all grievances and for the amending, strengthening and preserveing of the lawes Parlyaments ought to be held frequently" places the responsibility of amending law in the hands of Parliament. The context in which the Bill of Rights 1688 was enacted is an essential feature of the document and directly informs its purpose: it was aimed at redressing the power imbalance between the Sovereign and the people as represented by Parliament.

A more modern example can be found in s 15 of the Constitution Act 1986, which states that: "The Parliament of New Zealand continues to have full power to make laws." As with the articles of the Bill of Rights 1688, the words alone of s 15 of the Constitution Act are insufficient to determine the extent to which it legislates for the doctrine of parliamentary sovereignty and seems, by virtue of the word "continues", to rely on a pre-existing notion of the powers attributable to Parliament.

New Zealand inherited this doctrine through the English law heritage that forms the basis of New Zealand's legal system. While in the United Kingdom, the Bill of Rights 1688 is the result of historical events shaping its legal, political, and constitutional skeleton; McHugh observes that "the settler policy of New Zealand took Dicey's position and moulded it into an essentially ahistorical, highly idealised, not to say patriarchal, sense of constitutional being." 15

There is a vast body of academic writing about the nature of the doctrine and whether, for example, the doctrine is a political fact, rule of recognition, grundnorm, common law doctrine, or combination of these things. Some interpretations of the

\footnotetext{
${ }^{13}$ Joseph, Constitutional and Administrative Law, above n 3, at 488.

${ }^{14}$ Joseph, Constitutional and Administrative Law, above n 3, at 498.

15 P G McHugh "Tales of Constitutional Origin and Crown Sovereignty in New Zealand" (2002) 52 University of Toronto Law Journal 69 at 71.
} 
doctrine of parliamentary sovereignty consider it to be separate from "legislative supremacy". For example, Andrew Butler in "The Bill of Rights Debate: Why the New Zealand Bill of Rights Act 1990 is a Bad Model for Britain", draws a distinction between parliamentary sovereignty and legislative supremacy: ${ }^{16}$

\begin{abstract}
Simply put, supremacy of legislation is the principle that all legislation shall be regarded as valid and that none may be set aside by the courts. It will be clear that the New Zealand Bill is based on a rigid version of this principle: under s4 all legislation is exempt from challenges based on human rights norms. By contrast, parliamentary sovereignty is the principle that Parliament is the apex of the constitutional structure: it is the source of supreme law and has ultimate power to determine what will and what will not be law.
\end{abstract}

The orthodox view combines the concept of legislative supremacy (that Parliament alone can make or unmake any law, and that no person can override or set aside legislation) with the position that Parliament is the ultimate lawmaker and has unlimited law making powers. In addition, the doctrine of parliamentary supremacy provides that Parliament cannot bind its successors. In the legal context, this restriction has resulted in the useful development of the doctrine of implied repeal by the courts. The doctrine of implied repeal provides that if there contradictory provisions are present then the more recent legislation overrides the earlier legislation. In the political context, the doctrine has posed practical challenges for Parliament, particularly when trying to entrench legislation or, more controversially, when Parliament is seeking to limit its sovereign power. ${ }^{17}$ The doctrine has also posed practical difficulties for the courts when reviewing legislation for consistency with constitutional law and has resulted in the courts developing the principle of legality for constitutional statutes requiring Parliament to expressly repeal constitutional legislation as a counterweight to the doctrine of implied repeal otherwise.

The orthodox view takes the doctrine of parliamentary sovereignty one step further again and asserts that review of legislation by the courts is undemocratic because judges are not elected representatives of the people; and, therefore, judicial review of legislation undermines parliamentary sovereignty. For example, Ekins considers that even in countries that restrict legislative power under their constitution

\footnotetext{
${ }^{16}$ Andrew Butler "The Bill of Rights Debate: Why the New Zealand Bill of Rights Act 1990 is a Bad Model for Britain" (1997) 17 OJLS 323, 340 ["The Bill of Rights Debate"].

${ }^{17}$ See generally Richard Ekins, "The Authority of Parliament. A reply to Professor Joseph" (2005) 16 KCLJ 51 ["The Authority of Parliament"].
} 
and permit judges to strike down law, judicial review of legislation is undemocratic. ${ }^{18}$ In effect, the orthodox view adds two elements to the doctrine: that Parliament has illimitable powers to legislation (emphasis is placed on the ability of Parliament to make or unmake any laws) and that the courts cannot review the substance of the law because this is the exclusive dominion of Parliament.

Despite the assuredness with which the doctrine has been observed, there is debate about the extent to which the doctrine is absolute and whether there are other elements or restrictions to this doctrine. There are some of the practical restrictions on the doctrine because while Parliament could, in theory, enact laws beyond its territory, ${ }^{19}$ and reclaim the power to legislate for former dominions for which it has renounced its legislative competence ${ }^{20}$ - such laws would have no practical effect. Another practical restriction on the doctrine is that Parliament would not enact laws that were repugnant such as introducing racial or religious discrimination in a way that made people unequal. ${ }^{21}$ This restriction is political, rather than legal and, hence the "cannot" should possibly be replaced with "would not". Elliot describes them as "inhibitions" rather than restrictions and observes that: "the theory of parliamentary sovereignty errs by ascribing unlimited lawmaking power to an institution that is constrained ... by the dictates of political reality." 22 This proposition is controversial because it steps away from the orthodox view and suggests that Parliament does face restrictions on its power to legislation. An equally controversial issue is whether, Parliament can choose, because of the inherent power of parliamentary sovereignty, to forgo the protection of legislative supremacy for some legislation. ${ }^{23}$

Constitutional review of legislation under the Bill of Rights Act, which necessarily involves examination of the substance of the law, runs afoul of the orthodox view. However, it does not run afoul of the legislative supremacy kernel of the doctrine of parliamentary sovereignty because constitutional review of legislation under the Bill of Rights Act does encourage the courts seeking to usurp the democratic role of Parliament to determine policy and enact law to give effect to that policy.

\footnotetext{
${ }^{18}$ Ekins "The Authority of Parliament", above n 17, at 66.

19 Joseph, Constitutional and Administrative Law, above n 3, at 14.4.4.

${ }^{20}$ For example, Parliament cannot take back legislative competence for a country or territory that it has renounced. The United Kingdom has also devolved some legislative and administrative decision-making to Northern Ireland, Wales, and Scotland: Northern Ireland Act 1998, Government of Wales Act 1998, and Scotland Act 1998.

${ }^{21}$ Mark Elliot "United Kingdom: parliamentary sovereignty under pressure" (2004) 2 Int'1 Journal of Constitutional Law 545 at 546-547.

${ }^{22}$ Ibid, at 546-547.

${ }^{23}$ A Bulter, "The Bill of Rights Debate", above n 16, at 340.
} 
While the doctrine of parliamentary sovereignty is accepted as a core element of our constitutional arrangements it is only part of it and is, arguably, modified by other aspects of New Zealand's constitution. In contrast to the orthodox view supplied by Dicey and adopted by colonial New Zealand, Matthew Palmer describes a constitution in the following constitutional realist terms: ${ }^{24}$

A constitution is about public power and how it is exercised. A constitution is not just a document. ... A constitution is made up of structures, processes, principles, rules, conventions and even culture that constitute the ways in which government power is exercised.

In a separate article on constitutional culture, Matthew Palmer identifies three values of New Zealand's constitutional culture that influence the New Zealand constitution: egalitarianism, authoritarianism and pragmatism. ${ }^{25}$ These values are connected to four fundamental norms that Palmer considers underpins the New Zealand constitution: representative democracy, parliamentary sovereignty, rule of law and judicial independence, and the constitution as an unwritten evolving way of doing things. ${ }^{26}$ These values and norms are used to inform the analysis in this paper.

Palmer has also observed that: "a constitution continually exists in the actions, understandings and inter-relationships of those who operate it." ${ }^{11}$ This description is true of New Zealand's partly written and uncodified constitution. The executive, legislative and judicial branches of government have adapted as a result of the enactment of the Bill of Rights Act. The executive and legislative branches made changes to procedures in the Cabinet Manual and Standing Orders to give effect to the reporting function of the Attorney-General under s 7 of the Bill of Rights Act, and the courts have adapted interpretation and review practices to give effect to the rights in the Bill of Rights Act.

The constitutional arrangements also respond to those who use it to contest its workings. In practical terms, if a person or group of people disagree with a law then they can challenge it by lobbying members of Parliament for change, making a submission to a parliamentary select committee, changing voting preferences at an election, or advocating through the courts. The last form of challenge is not without

\footnotetext{
${ }^{24}$ Matthew Palmer "What is New Zealand's constitution and who interprets it? Constitutional realism and the importance of public office-holders" (2006) 17 Public Law Review 133 at 134 ["What is New Zealand's constitution"].

${ }^{25}$ Matthew Palmer "New Zealand Constitutional Culture" (2007) 22 NZULR 564 at 575-578.

${ }^{26}$ Palmer "New Zealand Constitutional Culture", above n 25, at 578-593.
} 
controversy. Review of legislation by the courts presents a challenge to orthodox view because review of legislation has traditionally been the domain of Parliament under the auspices of the doctrine of parliamentary sovereignty and representative democracy. Constitutional review by the courts expands the options for challenging legislation and policy thereby providing a new democratic avenue for the public.

This paper takes a practical and commonsensical approach to assess whether the legal authority and performance of constitutional review under the Bill of Rights Act is consistent with the constitution, including the formal standard set by the doctrine of parliamentary sovereignty. Because a constitutional realist lens invites us to look beyond the doctrines to the contributions made by different participants in the constitutional setting (such as members of Parliament, judicial decisions, officials, lawyers, academics, and the public) this paper will also look to these contributions in examining constitutional review under the Bill of Rights Act.

\section{B An introduction to Hansen}

The Supreme Court's decision in Hansen has been selected as the focus for this paper because it involves review of a legislative provision by the courts and it is the definitive case for clarifying that courts have a role in reviewing legislation for consistency with the Bill of Rights Act. The following paragraphs summarise the decision in Hansen to provide necessary context for the analysis in this paper.

In Hansen the Supreme Court deliberated whether s 6(6) of the Misuse of Drugs Act 1975 could be read consistently with the Bill of Rights Act by virtue of s 6 of the Bill of Rights Act. Section 6(6) of the Misuse of Drugs Act states that an accused who is found in possession of controlled drugs above a prescribed limit is deemed "until the contrary is proved" to be in possession of that drug for the purposes of sale or supply of that drug. This presumption places the onus on the accused to prove that, on the balance of probabilities, he or she did not intend to sell or supply the drugs to others: it is a "reverse onus" provision. Section 6 of the Misuse of Drugs Act makes it an offence to possess a controlled drug for use, sale, or supply and subs (6) states:

(6) For the purposes of subsection (1)(f), a person is presumed until the contrary is proved to be in possession of a controlled drug for any of the purposes in subsection (1)(c), (d), or (e) if he or she is in possession of the controlled drug in an amount, level, or quantity at or over which the controlled drug is presumed to be for supply (see section 2(1A)). 
The argument advanced by the counsel for Mr Hansen was that s 6(6) of the Misuse of Drugs Act is inconsistent with the right to be presumed innocent protected under s 25(c) of the Bill of Rights Act and that it could be interpreted under s 6 of the Bill of Rights Act with a lesser burden. Section 25(c) of the Bill of Rights Act states:

Everyone who is charged with an offence has, in relation to the determination of the charge, the following minimum rights:

$[\ldots]$

(c) The right to be presumed innocent until proved guilty according to law:

The appeal was dismissed and separate judgments were issued setting out the reasons. Three judges (Tipping J, McGrath J, and Anderson J) found that s 6(6) of the Misuse of Drugs Act was an unjustified limit on the right to be presumed innocent under s 5 of the Bill of Rights Act and that no consistent meaning could be established under s 6 of that Act; therefore, the provision had to stand by virtue of s 4 of the Bill of Rights Act which provides that an enactment cannot be overridden if it inconsistent with any provision of the Bill of Rights Act. While each of these judges came to the same conclusion there are differences to the approach each judge took to analysing the issues.

Elias CJ also found that there was no consistent meaning available under s 6 of the Bill of Rights Act but the Chief Justice took a different approach to applying the Bill of Rights Act akin to that of Cooke P in Ministry of Transport $v$ Noort (Noort) ${ }^{27}$ and concluded that s 5 did not have a role to play in Hansen. Blanchard $\mathrm{J}$, on the other hand, took the view that the limit imposed on the right by s 6(6) of the Misuse of Drugs Act was justified under s 5 of the Bill of Rights Act.

While the majority found that s 6(6) of the Misuse of Drugs Act was not a justified limit, could not be given a meaning consistent with the Bill of Rights Act, and applied s 4 of the Bill of Rights Act; none of these judgments issued a declaration of inconsistency. The decision in Hansen offers an opportunity to examine how the Supreme Court reviews legislation under the Bill of Rights Act and whether such review is legitimate.

\footnotetext{
${ }^{27}$ Ministry of Transport v Noort (Police v Curran) [1992] 3 NZLR 260 (CA) [Noort].
} 


\section{Legitimacy of constitutional review of legislation}

Constitutional review by the courts is a relative newcomer to the legal scene. Many countries, especially in Europe, adopted a centralised institutional model for constitutional review by the courts that is prescribed by their constitution or legislation after World War I and World War II. ${ }^{28}$ In contrast, the United States of America has had a form of constitutional review for more than 200 years. ${ }^{29}$ The term "constitutional review" in literature in other jurisdictions is used in an almost unconscious way; this means that the reader relies on the context to derive what authors mean when referring to constitutional review. ${ }^{30}$

In the New Zealand context, the term "constitutional review" has been employed to refer to a new form of judicial review that employs the proportionality test to review substantive matters under the auspices of the Treaty of Waitangi, Bill of Rights Act, and international human rights conventions. ${ }^{31}$ Beyond Joseph's writing, there is limited reference to the concept of constitutional review of legislation in New Zealand literature; instead the focus of the literature has been about the application of $\mathrm{s}$ 5 of the Bill of Rights Act to legislation and judicial review of administrative decisions. ${ }^{32}$ What is evident from the literature is that there are two aspects for determining the legitimacy of constitutional review: the nature of the legal authority for such review, and that the courts must perform constitutional review consistently with the constitution.

There are differing views about whether constitutional review by the courts is constitutional. Review of legislation by the courts is seen by some as unconstitutionally challenging the policy and law-making dominion of Parliament because the judicial

\footnotetext{
${ }^{28}$ The following countries adopted a centralised model of constitutional review after one or both of the World Wars: Austria, Belgium, Cyprus, Czech Republic, France, Germany, Hungary, Italy, Latvia, Lithuania, Luxembourg, Malta, Poland, Portugal, Slovakia, Slovenia, and Spain.

${ }^{29}$ Marbury v Madison 1 Cranch 137 (1803) was the case in which the United States Supreme Court determined that the power to review legislation could be derived from the United States Constitution.

${ }^{30}$ The term judicial review of legislation is also referred to in the literature and appears to be manifestly the same as constitutional review of legislation where the values concerned are constitutional in nature, and sometimes the terms are used interchangeably. See Dimitrios Kyritsis "Representation and Waldron's Objection to Judicial Review" (2006) 26 Oxford J Legal Stud 733.

${ }^{31}$ Joseph "Constitutional Review Now", above n 2; see also Joseph Constitutional and Administrative Law, above $\mathrm{n} 2$ at 21.11.

${ }^{32}$ See generally Andrew Butler "Judicial Indications of Inconsistency - a New Weapon in the Bill of Rights Armoury?" (2000) NZLR 43 ["Judicial Indications of Inconsistency"]; Petra Butler "Human Rights and Parliamentary Sovereignty in New Zealand" (2004) 35 VUWLR 341; Professor F M Brookfield "Constitutional Law" [1992] NZ Recent Law Review 231; Alex Conte and Sarah WynnWilliams "Declarations of inconsistency under the Bill of Rights. Part I: judicial jurisdiction, discretion or obligation?" (2003) 6(3) Human Rights Law \& Practice 243 ["Declarations of inconsistency"]; Alex Conte "Declarations of inconsistency under the Bill of Rights. Part II: an "effective remedy"? (2003) 6(3) Human Rights Law \& Practice 256; and Paul Rishworth "Human Rights and Bill of Rights" [1996] NZ Law Review 298.
} 
analysis examines the value and importance of the public purpose the legislation is seeking to achieve and, ultimately, where the balance of public interest or welfare lies with the right or with the offending legislative provision. ${ }^{33}$ These are seen as activities that belong to members of Parliament as the elected representatives of the public and any encroachment undermines parliamentary sovereignty. This paper concludes that constitutional review under the Bill of Rights Act in New Zealand is legitimate by examining the legal authority for constitutional review provided by section 5 of the Bill of Rights Act (chapter II) and how the courts exercise that jurisdiction in practice using Hansen as a case study (chapter III). Finally, this paper looks to the viable alternatives to the orthodox view for describing the constitutional relationship between Parliament and the courts (chapter IV).

${ }^{33}$ See generally Ekins “The Authority of Parliament”, above n 17. 


\section{LEGAL AUTHORITY FOR CONSTITUTIONAL REVIEW}

To examine the legal authority of constitutional review, this chapter poses two questions about the legal authority for such review: can review of legislation be performed under s 5 of the Bill of Rights Act and is review of legislation under the Bill of Rights Act constitutional review? Before commencing this assessment it is helpful to look at constitutional review in other jurisdictions to identify the core features of the legal authority.

\section{A Models of legal authority for constitutional review}

The legal authority for constitutional review of legislation in other jurisdictions, especially in non-common law jurisdictions, is usually found in their constitution or legislation and that authority sets out:

- who can perform constitutional review of legislation (for example, some jurisdictions establish a specialist constitutional court or reserve this power for a supreme court)

- the circumstances in which it can be performed (for example, abstract review of legislation or review in specific cases or both)

- the extent of the courts' powers (for example, whether they can strike down inconsistent legislation).

The European centralised model of constitutional review of legislation is described in the following terms: ${ }^{34}$

Most European countries have established special constitutional courts that are uniquely empowered to set aside legislation that runs counter to their constitutions. Typically, such constitutional courts review legislation in the abstract, with no connection to an actual controversy.

Comella's description above focuses on the institution carrying out constitutional review ("special constitutional courts"), authority for this review ("established" and "empowered"), when judges can exercise that power (when "legislation ... runs counter to their constitutions" and "courts review legislation in the abstract"), the standards

\footnotetext{
34 Victor Ferreres Comella "The European model of constitutional review of legislation: toward decentralisation?" (2004) 2(3) I CON at 461 [“The European Model of constitutional review”].
} 
against which legislation is assessed ("their constitutions"), and the remedies the court can apply ("set aside legislation").

Similarly, Alexy, in the context of designing a formula for balancing competing interests in cases, describes constitutional review in Europe as "an expression of the priority or superpriority of constitutional rights over and against parliamentary legislation." 35 Alexy then goes on to unpack constitutional review further: ${ }^{36}$

Constitutional review, however, consists of more than assertions concerning constitutionality. The constitutional court not only says something but also does something. It typically has power to invalidate unconstitutional acts of the parliament. This kind of participation in legislation means that the activity of constitutional courts has not only a propositional or discursive character but also an institutional or authoritative one.

Alexy's descriptions of constitutional review contain the same elements of Comella's description: institution, authority, method, standard and remedy. These examples reflect the legal culture of the centralised model of constitutional review where constitutional review is expressly permitted by a constitution or legislation, and that certain powers are conferred on judges to carry it out.

In contrast, the model of constitutional review in the United States of America (United States) reveals that authority for constitutional review does not have to be expressly conferred on the courts by the Legislature. Jurisdiction for constitutional review was not expressly conferred by the United States Constitution but has, nevertheless, been derived from it. ${ }^{37}$ Comella describes the approach taken in the United States as a decentralised model because all courts have the ability to determine the constitutional validity of a statute and they determine it in the context of a specific cases rather than abstract review of legislation. ${ }^{38}$ Further, Comella considers that this approach is sustainable in a common law system by virtue of the doctrine of precedent that means that lower courts are bound to follow the decisions of higher courts. ${ }^{39}$

In other common law countries there have been a variety of approaches; for example, the Canadian Charter of Rights and Freedoms (the Canadian Charter) ${ }^{40}$

\footnotetext{
${ }^{35}$ Robert Alexy “Balancing, Constitutional Review, and Representation” 3 Int'l J Const L 572 at 577.

${ }^{36}$ Alexy "Balancing, Constitutional Review, and Representation", above n 35, at 577.

${ }^{37}$ Marbury v Madison, above n 29.

${ }^{38}$ Comella "The European model of constitutional review", above n 34, at 461 and 466.

${ }^{39}$ Comella "The European model of constitutional review", above n 34, at 461 and 466.

${ }^{40}$ Canada Act 1982 (UK) RS C 1982 Schedule B, Part 1.
} 
permits the courts to strike down legislation that is inconsistent with the rights contained in the Charter, whereas the United Kingdom Human Rights Act 1998 does not empower the courts to strike down legislation but does permit the courts to issue a declaration of incompatibility if legislation is inconsistent with the rights in that Act

There is no consistent approach to how the legal authority for constitutional review of legislation is conferred with the type of authority varying according to the legal system. For example, it and be carefully prescribed by legislation or in a constitution (such as in Spain), it may be generally conferred (such as in Canada and the United Kingdom) or it may be interpreted as part of the constitution by the courts (as in the United States). The common thread is that the authority for constitutional review of legislation permits judicial review of legislation to determine whether the legislation is consistent with the constitution or a set of constitutional standards such as human rights.

\section{B Legal authority for review of legislation under the Bill of Rights Act}

One way in which the legal authority for review of legislation has been conferred on the courts is through legislation; sometimes that authority is detailed and in others it is generally conferred. The approach of New Zealand courts has been to review legislation for consistency with the Bill of Rights Act under s 5 of that Act; there has however been debate, including in minority judgments such as those of Chief Justice Elias in Hansen and Cooke P in Noort, about whether s 5 does confer this authority. While the majority in Hansen reviewed s 6(6) of the Misuse of Drugs Act under s 5 of the Bill of Rights Act, s 5 and the Bill of Rights Act are silent about when, and by whom, s 5 should be used. Section 5 of the Bill of Rights Act states:

Subject to section 4 of this Bill of Rights, the rights and freedoms contained in this Bill of Rights may be subject only to such reasonable limits prescribed by law as can be demonstrably justified in a free and democratic society.

Section 5 of the Bill of Rights Act reflects the position that rights are not absolute: ${ }^{41}$

[Section 5] reflects the reality that rights do not exist in a vacuum, that they may be modified in the public interest to take account of the rights of others

\footnotetext{
${ }^{41}$ Noort, above n 27, at 283 per Richardson J. See also Simpson v Attorney-General (Baigent's case) [1994] 3 NZLR 667 (CA) at 708 per Gault J [Baigent's Case]; and Hansen, above n 8, at [190] per McGrath J.
} 
and the interests of the whole community. Equally clearly s 5 guards those rights by insisting that they may be regarded as modified only where the stringent tests laid down are met.

Section 5 applies to limits and requires any limits on the rights and freedoms contained in the Bill of Rights Act to be: reasonable, prescribed by law, demonstrable, and justifiable. A limit is a restriction that impinges on a right or freedom and can come in any form such as legislation, policies, decisions, activities and practices that are prescribed by the law. The limit must be created or performed by a person or organisation captured by s 3 of the Bill of Rights Act. ${ }^{42}$ In order to avail itself of s 5 of the Bill of Rights Act the limit must be prescribed by law. ${ }^{43}$ Setting out rules, benefits, and obligations in legislation is one of the ways in which the law is prescribed. Therefore, legislative provisions, such as s 6(6) of the Misuse of Drugs Act, are captured by s 5 of the Bill of Rights Act because they are capable of posing a limit on a right that is prescribed by law and an act of the legislative branch of the government.

The question of whether the courts could review legislation under the Bill of Rights Act was an early topic of debate. In 1992, the Court of Appeal in Noort considered whether the actions of police officers in roadside alcohol screening could be interpreted to enable motorists to contact a lawyer consistently with s 23(1)(b) of the Bill of Rights Act. ${ }^{44}$ The majority of the Court of Appeal found that the provisions of the Transport Act 1962 did not pose a limit on the Bill of Rights Act because that roadside alcohol screening could be performed consistently with s 23(1)(b) of the Bill of Rights Act. In coming to this decision four of the five judges took that opportunity to describe an analytical framework for assessing the rights breaches under the Bill of Rights Act, the courts' role, and application of s 5 of the Bill of Rights Act.

Richardson and Hardie-Boys JJ in Noort both signal that the courts have a role to play in determining whether statutory provisions are justified under s 5 of the Bill of Rights Act. Richardson J demonstrates the courts' role through his analysis, while Hardie-Boys J expressly states: ${ }^{45}$

\footnotetext{
${ }^{42}$ Section 3 of the Bill of Rights Act states: This Bill of Rights applies only to acts done- (a) By the legislative, executive, or judicial branches of the government of New Zealand; or (b) By any person or body in the performance of any public function, power, or duty conferred or imposed on that person or body by or pursuant to law.

${ }^{43}$ Hansen, above n 8, at [180] per McGrath J. See generally Andrew Butler and Petra Butler The New Zealand Bill of Rights Act: A Commentary (LexisNexis, Wellington, 2005) at 6.13.

${ }^{44}$ Section 23(1)(b) of the Bill of Rights Act states that: "Everyone who is arrested or who is detained under any enactment ... [s] hall have the right to consult and instruct a lawyer without delay and to be informed of that right."

${ }^{45}$ Noort, above n 27, at 287 per Hardie-Boys J.
} 
To view the matter in this way is no arrogation by the Court of the responsibility of determining what is a reasonable limit, and what can be demonstrably justified in a free and democratic society. Rather it is to see s 5 as a mechanism to secure recognition of the Act's rights and freedoms to the fullest extent that is reasonable and practicable in the statutory context.

In contrast to this position, two judgments in Noort considered that the court did not have a role to play under s 5 of the Bill of Rights Act. The two main objections were that $\mathrm{s} 5$ is targeted at the legislative and executive branches not the courts and that s 4 of the Bill of Rights Act precludes judicial consideration of limits. The discourse of Cooke $\mathrm{P}$ and Gault $\mathrm{J}$ in Noort precluding judicial consideration of limits under s 5 of the Bill of Rights Act is rarely repeated in later cases and does not reflect the prevalent application of the s 5 of the Bill of Rights Act. The noteworthy exception to this approach is Elias CJ's judgment in Hansen. Given the challenge these positions pose to the legal authority for constitutional review by the courts, these two objections are discussed below.

\section{Section 5 of the Bill of Rights Act targeted at Legislature and Executive}

An interpretation of $\mathrm{s} 5$ of the Bill of Rights Act is that it is targeted at the legislative and executive branches of the government, not at the courts. In issuing his dissenting judgment in Noort, Gault J contrasts s 5 with the s 1 of the Canadian Charter and states: ${ }^{46}$

Section 5 clearly serves a different role in the New Zealand Bill of Rights Act than does s 1 of the Canadian Charter. It seems rather directed to the role of the Attorney-General under s 7. It may assist in a conflict between common law rules and the fundamental rights but I can see no part for it to play in cases of statutory inconsistency.

Elias CJ in Hansen draws on the legislative scheme of the Bill of Rights Act as evidence of a non-judicial purpose for s $5:{ }^{47}$

As s 3 makes clear, the New Zealand Bill of Rights Act is directed not only at those interpreting and applying the enacted rights and freedoms. Section 5 is

\footnotetext{
${ }^{46}$ Noort, above n 27, at 295 per Gault J (dissenting); and at 271 per Cooke P.

${ }^{47}$ Hansen, above n 8, at [23] per Elias CJ.
} 
directed to those making or advising on the making of legal prescriptions potentially limiting of Part 2 rights and freedoms. In addition, as indicated, s 5 may give rise to a substantive determination of compliance.

This construction of the purpose of s 5 by Elias CJ would have s 5 apply only to Bills and draft legislation not to the law once enacted. This interpretation is incongruous with the concept of "limit" that is captured by s 5 which includes legislation is because it is capable of imposing a limit on a right.

Section 5 is silent about who is to apply s 5 of the Bill of Rights Act. In contrast to s 5, ss 4 and 7 of the Bill of Rights Act contain express statements about to whom they apply. Section 4 specifically refers to the fact that no court shall, in essence, render legislation invalid or refuse to apply it. Section 7 is an instruction to the Attorney-General to bring to Bills and provisions inconsistent with the Bill of Rights Act to the attention of the House of Representatives.

The Bill of Rights Act, by virtue of s 3, applies to the three branches of Government (Executive, Legislature, and the Judiciary) requiring them to affirm, protect, and promote human rights and fundamental freedoms in the exercise of their functions. The way the Bill of Rights Act applies to each branch varies according to the role each branch plays in governing New Zealand. This means that public officeholders, including those providing public services in the private sector, must act consistently with the rights and freedoms in the Bill of Rights Act unless there is a justification for limiting a right.

While s 5, like s 6, is silent about to who applies it; s 3 of the Bill of Rights Act makes it clear that the Act applies to the legislative, executive and judicial branches of government (and to those performing public functions as per s 3(b) of the Bill of Rights Act) and it is consistent with the scheme and purpose of the Act to conclude that the courts can review legislation under s 5 of the Bill of Rights Act. Furthermore, the courts have come to this conclusion as is reflected in the majority decisions in Hansen.

\section{Section 4 of the Bill of Rights Act precludes review of legislation}

Section 5 of the Bill of Rights Act opens with the statement "subject to section 4" and this statement has been interpreted to exclude review of legislation by the courts under s 5 of that Act. Section 4 of the Bill of Rights Act states:

No court shall, in relation to any enactment (whether passed or made before or after the commencement of this Bill of Rights),- 
(a) Hold any provision of the enactment to be impliedly repealed or revoked, or to be in any way invalid or ineffective; or

(b) Decline to apply any provision of the enactment-

by reason only that the provision is inconsistent with any provision of this Bill of Rights.

Cooke P in Noort notes that s 5 of the Bill of Rights Act is subject to s 4, and then relies on s 4 as precluding review of legislation if an enactment is inconsistent with the Bill of Rights Act. ${ }^{48}$ In contrast, academic writing on the Bill of Rights Act at the same time supported judicial review of legislation. For example, Brookfield notes Cooke P's statement in Noort about the limited use of s 5 but proposes that the courts can examine justified limitations under s 5 because he considers that such examination is not precluded by s 4 but that the wording actually leaves this possibility open: ${ }^{49}$

The essential point is that it is assumed, in the prohibition directed to the courts in s 4, that they may hear argument not only about the nature and definition of the rights and freedoms in Part II but also about justified limitations under s 5.

Despite Cooke P's position in Noort, subsequent cases saw the courts employ s 5 to analyse limits (legislative or otherwise) on the rights and freedoms in the Bill of Rights Act. However, Elias CJ in Hansen observes that: ${ }^{50}$

The sequence suggested by which consideration of justification under $\mathrm{s} 5$ is a necessary step in determining whether an enactment is consistent with a right under Part 2, would set up a soft form of judicial review of legislation which seems inconsistent with $\mathrm{s} 4$ of the Act.

In support of this conclusion Elias CJ considers the legislative history of the Bill of Rights Act and late inclusion of s 4 to exclude the ability to strike down legislation as removing the courts' requirement to review legislation under s 5 of the Act. ${ }^{51}$ Again, this narrow interpretation would result in s 5 applying only to draft legislation and this approach seems incongruous to the concept of "limit" in s 5 of the Bill of Rights Act that includes instruments and activities prescribed by law.

\footnotetext{
${ }^{48}$ Noort, above n 27, at 271 per Cooke P.

${ }^{49}$ Brookfield "Constitutional Law", above n 32, at 239.

${ }^{50}$ Hansen, above n 8, at [6] per Elias CJ.

${ }^{51}$ Ibid, at [19] per Elias CJ.
} 
Furthermore, s 4 uses the term "inconsistent"; whether a limit is inconsistent with the Bill of Rights Act is determined by analysis under s 5 of that Act.

The approach preferred by the courts, however, appears to be that the qualification "subject to section 4" goes to the outcome of the analysis: that even if an inconsistency is found s 4 means that the offending provision prevails: ${ }^{52}$

Subject only to the application of s 5, which concerns justified limitations, the effect of s 4 is that any inconsistent legislation prevails over the Bill of Rights, irrespective of when it is enacted, to the extent of the inconsistency. Section 4 thereby reaffirms the primacy of the legislature and makes clear that the courts' role in applying the Bill of Rights in ascertaining the meaning of legislation remains one of interpretation within the limits of the legislative directions specified in that Act.

An alternative reading of Elias CJ position is that she does not consider that s 5 of the Bill of Rights Act imposes a duty on the courts to review legislation; this alternative reading is plausible, in light of her discussion in the judgment that $\mathrm{s} 5$ may be in issue in some cases where an inconsistent enactment is sought to be justified and she commends the approach taken by the Canadian Supreme Court in $R v$ Oakes. ${ }^{53}$ It appears that Her Honour is suggesting that s 5 is not essential in every case; for example, if a meaning consistent with s 6 is possible then recourse to s 5 for review of a legislative provision may not be required.

\section{Current approach to section 5 of the Bill of Rights Act}

Despite the misgivings about the legal authority outlined above, the courts have taken a largely practical approach to reviewing legislation under the Bill of Rights Act. The judgments in Noort signal a cautious defining of the courts' role, subsequent decisions trace a path towards more emphatic statements of the courts' role: Simpson $v$ Attorney-General (Baigent's case), ${ }^{54}$ Quilter v Attorney-General ${ }^{55}$ Moonen v Film and

\footnotetext{
${ }^{52}$ Ibid, at [179] per McGrath J; see also [16] per Elias CJ; [60] per Blanchard J; [157] per Tipping J.

${ }^{53}$ Ibid, at [42] per Elias CJ.

${ }^{54}$ Baigent's case, above n 41.

${ }^{55}$ Quilter v Attorney-General [1998] 1 NZLR 523 (CA). See generally Mark Henaghan "Same-sex Marriages in the Court of Appeal" [1998] NZLJ 40; and Paul Rishworth "Reflections on the Bill of Rights Act after Quilter v Attorney-General" [1998] NZ Law Review 683.
} 
Literature Board of Review (Moonen (No.1)), ${ }^{56} R v$ Poumako (Poumako) ${ }^{57}$ and $R v$ Pora $^{58}$.

The Court of Appeal decision in Moonen (No.1) is noteworthy because the decision is a single judgment for the court, delivered by Tipping $\mathrm{J}$, which attributes the courts with an active role under the Bill of Rights Act. The Court of Appeal was asked to determine whether the Office of Film and Literature Classification (the decisionmakers under the Films, Videos, and Publications Classification Act 1993) and the Film and Literature Board of Review (the Board) had taken proper account of the right to freedom of expression under s 14 of the Bill of Rights Act in their decision to deem specific material as objectionable. In relation to the role of the courts under $\mathrm{s} 5$, Tipping J states that: ${ }^{59}$

\begin{abstract}
That purpose [of section 5] necessarily involves the Court having the power, and on occasions the duty, to indicate that although a statutory provision must be enforced according to its proper meaning, it is inconsistent with the Bill of Rights, in that it constitutes an unreasonable limitation on the relevant right or freedom which cannot be demonstrably justified in a free and democratic society.
\end{abstract}

Tipping $\mathrm{J}$ also drew attention to the fact that courts would, necessarily, be required to make some value judgments in the course of analysis under s 5 of the Bill of Rights Act. ${ }^{60}$ This Court of Appeal decision also offered guidance for the application of s 5 of the Bill of Rights Act including at what point in the analysis s 5 should be considered: s 6 then s 5 then s $4 .^{61}$ The analysis under s 5 was to include consideration of the objective that the offending provision sought to achieve and whether it is a proportionate response that interferes with the right as little as possible. $^{62}$ The applicant appealed the Board's reconsideration of the objectionable material and its application of the Bill of Rights Act (the appeal is referred to as "Moonen (No.2)"). ${ }^{63}$ Richardson P gave the judgment for the Court of Appeal in Moonen (No.2) dismissing the appeal and finding that the Board had applied the Bill of

\footnotetext{
${ }^{56}$ Moonen v Film and Literature Board of Review [2000] 2 NZLR 9 (CA) [Moonen (No.1)].

${ }^{57} R$ v Poumako [2000] 2 NZLR 695 (CA).

${ }^{58} R$ v Pora [2001] 2 NZLR 37.

${ }^{59}$ Moonen (No.1), above n 56, at [20] per Tipping J.

${ }^{60}$ Moonen (No.1), above n 56, at [18] per Tipping J.

${ }^{61}$ Moonen (No.1), above n 56, at [17]-[19] per Tipping J.

${ }^{62}$ Moonen (No.1), above n 56, at [17]- [18] per Tipping J.

${ }^{63}$ Moonen v Film and Literature Board of Review [2002] 2 NZLR 754 (CA) [Moonen (No.2)].
} 
Rights Act correctly. In addition, Richardson P reminded everyone that the five-step analytical approach outlined in Moonen (No.1) for applying the Bill of Rights Act was intended as guidance and that it was not intended to be prescriptive and that other approaches remain are open. ${ }^{64}$

Likewise, the Court of Appeal in Poumako added more fuel to the discourse because it involved the review of a legislative provision that feel squarely into the domain of judicial experience (criminal proceedings) and was an emotive issue on which Parliament chose to respond emphatically. The Court of Appeal deliberated the question of whether a retrospective sentencing requirement s 2(4) of the Criminal Justice Amendment Act (No2) 1999 (amending s 80 of the principal Act) was inconsistent with s 25(g) of the Bill of Rights Act. Section 25(g) requires that an accused has the benefit of the lesser penalty if convicted of an offence for which the penalty has been varied.

The Court of Appeal in Poumako held unanimously that the provisions were inconsistent and that legislative revision was desirable but the majority did not issue a joint declaration of inconsistency. Separate judgments were issued and they exhibited various mental gymnastics on the part of the Court of Appeal to reconcile rights with clear parliamentary intent that was contrary to the right. This decision also overtly discusses the courts' power to issue declarations of inconsistency with Thomas $\mathrm{J}$ (dissenting) issuing such a declaration. Gault $\mathrm{J}$ (for Richardson $\mathrm{P}$ and Keith $\mathrm{J}$ also) states that the burden is on the Crown to prove a limit is justified under s 5 and notes that the Crown has not put forward any such arguments. Gault $\mathbf{J}$ comments that it is desirable for there to be legislative reconsideration of the offending provision and states that for declarations of inconsistency to be issues there needs to be arguments from both parties on the issue of justifications. ${ }^{65}$ Henry J endorses Gault J's recommendation for legislative reconsideration but does not discuss the application of $\mathrm{s} 5$ only noting the lack of reasons put forward for the enactment of the offending provision and the necessity of having argument from both sides before issuing a declaration of inconsistency. ${ }^{66}$

In contrast, Thomas $\mathrm{J}$ in Poumako discusses the role of $\mathrm{s} 4$ of the Bill of Rights Act, the approach to s 5 in Moonen (No.1) and the role of the court - particularly in the context of issuing a declaration of inconsistency. Thomas $\mathrm{J}$ expresses that the court has a supervisory role under the Bill of Rights Act and this includes determining: "in

\footnotetext{
${ }^{64}$ Ibid, at [14] per Richardson P.

${ }^{65}$ Poumako, above n 57, at [42] per Gault J.

${ }^{66}$ Ibid, at [67] per Henry J.
} 
appropriate cases whether a legislative restriction represents a reasonable limitation, such as can be justified in a free and democratic society." ${ }^{, 67}$ Thomas $\mathrm{J}$ does not, however, overtly apply s 5 in the course of the analysis before issuing such a declaration.

In 2007, the majority in Hansen favoured analysis of legislation under s 5, expressly or by virtue of their analysis; with Elias CJ appearing to dissent on this point. This position is reasoned in several ways. Anderson $\mathrm{J}$ attributes Parliament with a deliberate decision to permit such a review: ${ }^{68}$

It is indicative of the strength of our democratic institutions that Parliament, although not countenancing its being overruled has, by the terms of the Bill of Rights Act, accepted the prospect of judicial assessment of the consistency of its enactments with affirmed rights and freedoms.

Tipping $\mathrm{J}$ views $\mathrm{s} 5$ as an instruction to both Parliament and the courts, and describes the courts role as that of: "keeping Parliament faithful to the s 5 instruction, but with some inherent room for parliamentary appreciation."69 Blanchard J's statement of the courts role under s 5 follows a similar line, elaborating that the court must perform this role: "within the bounds of their jurisdiction and processes, an analysis of the legitimacy of challenged statutory provisions in their particular societal context." 70

Therefore, despite the objections to review of legislation under s 5 of the Bill of Rights Act, the majority decision in Hansen presents clear legal authority for the courts to perform such review. Furthermore, this review of legislation is constitutional review because of the constitutional values it seeks to promote and protect.

\section{Review of legislation under the Bill of Rights Act as constitutional review}

A law, policy, or practice is constitutional if it is "in harmony with, or authorized by, the political constitution" or "belonging to the very constitution or composition of anything; forming an essential part or element; essential."71 A

\footnotetext{
${ }^{67}$ Ibid, at [95] per Thomas J.

${ }^{68}$ Hansen, above n 8, at [266] per Anderson J.

${ }^{69}$ Hansen, above $\mathrm{n} 8$, at [106] per Tipping J.

${ }^{70} \mathrm{Ibid}$, at [82] per Blanchard J.

71 Oxford English Dictionary Online (10 July 2009). Note the Concise Oxford Dictionary of Current English (Clarendon Press, Oxford, 1995) that describes constitutional as "of, consistent with, authorised by, or limited by a political constitution." Compare, Palmer "What is New Zealand's constitution", above n 24, at 137: "A rule should be regarded as constitutional if it plays a significant role in
} 
constitution also informs the way in which the branches of government work together and the fundamental standards they must meet in the exercise of their duties. ${ }^{72}$ Constitutional review of legislation is prefaced on the idea that the standards against which the court reviews legislation are constitutional standards. The Bill of Rights Act is part of the New Zealand constitution and the rights and freedoms affirmed in that Act are constitutional standards because they contain values that reflect the fundamental principles for equitable treatment of all people in New Zealand that act to guide the governance of New Zealand. ${ }^{73}$

The courts act as an essential check on Parliament in a democracy, especially when it comes to the protection of human rights and in New Zealand they play a part in ensuring the transparency of parliamentary decision-making. This recognises the fact that while members of Parliament are the elected representatives their role is more akin to a proxy than a representative. ${ }^{74}$ This transparency means that the public of New Zealand can make meaningful decisions about how to hold Parliament accountable for its actions and whether to lobby for change. For example, public concern expressed about the Electoral Finance Act 2007 and the action sought by the courts in the Boscawen litigation ${ }^{75}$ is likely to have influenced the repeal of that Act by the Electoral Amendment Act 2009 when the government changed after the General Election 2008.

The discussion by Justice Tipping in Hansen about the role of the courts under the Bill of Rights Act is illustrative of the courts' constitutional role: ${ }^{76}$

Parliament has nevertheless given the New Zealand courts a significant review role. That role arises by virtue of $s 5$, which requires that a limit on a right or freedom be demonstrably justified. Determination of this question necessarily falls to the courts. Parliament must therefore be taken to have disclaimed any kind of presumptive justification simply because it has enacted the limit. The onus is on those who claim the limit is reasonable and justified to satisfy the court that this is demonstrably so.

influencing the generic exercise of public power - whether through structures, processes, principles, rules, conventions or even culture."

${ }^{72}$ See Palmer "What is New Zealand's constitution", above n 24, at 134.

73 Joseph "Constitutional Review Now", above n 3, at 90-93.

${ }^{74}$ See Kyritsis "Representation and Waldron's Objection to Judicial Review”, above n 30.

${ }^{75}$ Boscawen v Attorney-General [2008] NZAR 44 (HC); Boscawen v Attorney-General [2008] NZAR 468 (HC); and Boscawen v Attorney-General [2009] 2 NZLR 229.

${ }^{76}$ Hansen, above $\mathrm{n} 8$, at [108] per Tipping J. 
In the New Zealand context this constitutional role of the courts under the Bill of Rights Act has been counterbalanced by a veto: s 4 of the Bill of Rights Act which provides that no court shall strike down or refuse to apply any provision that is inconsistent with any provision of the Bill of Rights Act. The constitutional status of the Bill of Rights Act is important because there are different interpretative principles the courts apply to constitutional instruments that, in turn, lend themselves to greater protection by the courts. Two arguments are often made to diminish the constitutional status of the Bill of Rights Act: that the Bill of Rights Act is not entrenched and that it is not supreme law. These arguments are canvassed below.

\section{$1 \quad$ Bill of Rights Act not entrenched}

The Bill of Rights Act is not entrenched. This means that a simple majority in the House of Representatives can amend or repeal the Bill of Rights Act. The lack of entrenchment of the Bill of Rights Act is often argued to diminish the constitutional status of the Bill of Rights Act and advocate for a narrow interpretation of a right in the Bill of Rights Act. ${ }^{77}$ The lack of entrenchment does not, however, undermine the ability for courts to give rights their fullest extent within the scheme of the Bill of Rights Act. In Baigent's Case, Gault J correctly distinguishes between the lack of entrenchment for the Bill of Rights Act and the courts role: ${ }^{78}$

The [Bill of Rights Act] states the law of New Zealand. That it is not entrenched does not affect that. Entrenchment and constitutional status go to the extent to which the legislature is bound by the particular law. The result may be a restraint upon Parliament's law-making powers but it makes no difference to the strength of the law where it is to be applied. The Constitution Act 1986 also is not entrenched. Accordingly, in the present case I do not see that whether or not it has constitutional status really assists.

It is not the lack of entrenchment for the Bill of Rights Act that limits the courts' role: it is the presence of s 4 of the Bill of Rights Act. Gault J's position on the constitutional status in this context is limited to the form and not the content of the Bill of Rights Act and reflects the fact that in Baigent's case the focus is on the activities of State actors, not the empowering provision. The development of the remedy of compensation by Gault $\mathrm{J}$ and his colleagues in Baigent's case employs interpretation

\footnotetext{
${ }_{77}^{7}$ See, for example, the arguments of counsel in Baigent's Case, above n 41 .

${ }^{78}$ Baigent's Case, above n 41, at 706 per Gault J.
} 
and analytical practices reserved for constitutional statutes demonstrating the special nature of the values of the rights and freedoms in the Bill of Rights Act and ensuring there is a tangible remedy where public office holders fail to act in accordance with the Bill of Rights Act.

Bill of Rights Act not supreme law

"Supreme law" is constitutional shorthand for situations when the courts have the ability to strike down legislation on the grounds that it is unconstitutional or inconsistent with a constitutional statute. Kyritsis summarises this feature of constitutional review in the following terms: ${ }^{79}$

... constitutional review bestows on judges the power to strike down democratically reached decisions, that is, decisions made by a democratically elected legislature, which they find in contravention of the abstract moral principles enshrined in the constitution.

The lack of supreme law status, however, is not fatal to the Bill of Rights Act's constitutional status. This is because the constitutional relationship between the branches of government is complex and relies on each branch making their contribution based on their institutional advantages. The institutional advantage of the courts is that they are independent and impartial when interpreting and applying the law - they do not bring political agendas to their decision-making and are not reliant on elections for their continuation in office. Tipping $\mathrm{J}$ in Hansen, after stating that a major purpose of the Bill of Rights Act is to protect minority interests from an oppressive majority, observes that:

The point is essentially the same whether the courts have power to strike down legislation or whether, as in New Zealand, they do not, and can only declare that certain legislation, although operative, is inconsistent with the Bill of Rights. ${ }^{80}$

The United Nations Human Rights Committee has expressed concern that the Bill of Rights Act is an ordinary statute and that it is possible to enact legislation

\footnotetext{
${ }^{79}$ Kyritsis “Representation and Waldron's Objection to Judicial Review", above n 30.

${ }^{80}$ Hansen, above $\mathrm{n} 8$, at [107] per Tipping J.
} 
inconsistently with the Bill of Rights Act that deprives victims of a domestic remedy. ${ }^{81}$ While supreme law status is salient in the international human rights context and is a policy option that the Executive and Parliament will hopefully include on its agenda for its review of New Zealand's constitution arrangements; ${ }^{82}$ the lack of supreme law status is not determinative as to whether the Bill of Rights Act is part of the constitution.

\section{Preservation of legislative supremacy: section 4 of the Bill of Rights Act}

The courts have one crucial constitutional constraint placed on their exercise of constitutional review: they are not able to strike down legislation. Section 4 of the Bill of Rights Act explicitly retains the legislative supremacy of Parliament. The express protection of legislative supremacy in the Bill of Rights Act contrasts starkly with that taken in Canadian Charter under which the courts have held legislative provisions to be void because they are not a justified limitation on a right (or saved by s 33 of the Canadian Charter). Section 33 of the Canadian Charter clearly places: "the responsibility for trumping rights and freedoms on political shoulders. Parliamentarians can decide to trump the Charter ... but they must do so explicitly and accept the public relations consequences of their actions." 83

In the New Zealand context, as reflected in s 4 of the Bill of Rights Act and observed in academic writing: parliamentary sovereignty is still at the core of New Zealand's constitution and a reflection of the New Zealand constitutional norm of a strong representative democracy. ${ }^{84}$ Matthew Palmer in "New Zealand Constitutional Culture" attributes this approach to a: ${ }^{85}$

...[s]uspicion of judges' ability to frustrate the will of a democratically elected government taps into a deep root in the New Zealand national constitutional culture. The egalitarian and apparently democratic ethic remains strong in New Zealand.

\footnotetext{
${ }^{81}$ United Nations Human Rights Committee Consideration of reports submitted by States Parties under article 40 of the Covenant: concluding observation of the Human Rights Committee: New Zealand, 7 August 2002, CCPR/CO/75/NZL. See also Andrew Butler "Strengthening the Bill of Rights" (2000) 31 VUWLR 129, at 136.

${ }^{82}$ Prime Minister John Key "Statement to Parliament" (Statement to Parliament, 9 February 2010.

${ }^{83}$ A Butler "The Bill of Rights Debate", above n 16, at 342.

${ }^{84}$ See generally A Butler "The Bill of Rights Debate", above n 16, at 340; Joseph Constitutional and Administrative Law, above n 3, at ch14; and John Burrows and Ross Carter Statute Law in New Zealand (LexisNexis, Wellington, 2009) at ch 2; and Palmer "New Zealand Constitutional Culture", above n 25.

${ }^{85}$ Palmer "New Zealand Constitutional Culture", above n 25, at 586.
} 
The Justice and Law Reform Committee also observe this attitude in considering submissions on the White Paper, and judges and other academics have made similar observations. ${ }^{86}$

\section{Constitutional character of the Bill of Rights Act in practice}

The judgments of the courts are also a source of constitutional law and a further example of the Bill of Rights Act being given constitutional status is reflected in how it is interpreted and applied by the courts and then, in turn, by the other branches of government. Ordinarily, if there are contradictory provisions the more recent legislation overrides the earlier legislation. This principle is called the doctrine of implied repeal and it is a principle of statutory interpretation. ${ }^{87}$ The courts apply this doctrine in recognition of the concept of parliamentary sovereignty: the belief that an earlier Parliament cannot bind its successors and that the most recent articulation of a law is the authoritative version. The doctrine of implied repeal, if applied to the Bill of Rights Act, would undermine the purpose of the Act "to affirm, protect, and promote human rights and fundamental freedoms in New Zealand" 88 because it would only apply to legislation enacted before the Bill of Rights Act. The courts have developed and employed the principle of legality to reconcile the tension between the doctrine of implied repeal and constitutional statutes: ${ }^{89}$

At common law, two developments have strengthened the normative force of civil and political rights: the principle of legality (Parliament must "speak clearly" if it wishes to abrogate rights) and the protection of statutory rights from implied repeal (ordinary statutes may be impliedly repealed, constitutional and human rights statutes may not).

The rights and freedoms in the Bill of Rights Act are principles that apply to legislative provisions regardless of when they were enacted: the courts have recognised

\footnotetext{
${ }^{86}$ Justice and Law Reform Committee Interim Report of the Justice and Law Reform Committee, Inquiry into the White Paper - A Bill of Rights for New Zealand [1986-1987] X AJHR I.8A at 8-23 [Interim Report]; and Justice and Law Reform Committee Final Report of the Justice and Law Reform Committee on a White Paper - A Bill of Rights for New Zealand [1987-1990] AJHR I.8C at 3 [Final Report]. See also Hansen, above n 8, at [187]-[189] per McGrath J; A Butler "The Bill of Rights Debate", above n 16, at 324; Burrows and Carter Statute Law in New Zealand, above n 84, at 30-31.

${ }^{87}$ See generally Burrows and Carter Statute Law in New Zealand, above n 84, at ch 8 and ch 11

${ }^{88}$ New Zealand Bill of Rights Act 1990, long title.

${ }^{89}$ Joseph Constitutional and Administrative Law, above n 3, at 7. See also Palmer "What is New Zealand's constitution", above n 24, at 139. This approach has been affirmed in the United Kingdom, see Thoburn v Sutherland City Council [2002] 4 All ER 156.
} 
the primacy of the Bill of Rights Act by: "displacing the doctrine of implied repeal" 90 The application of the principle of legality is judicial recognition of the constitutional status of the Bill of Rights Act.

The courts are not alone in according the Bill of Rights Act constitutional status; this constitutional status is also accepted by academics and observed by the Executive and Parliament. This is relevant because, as noted by Rishworth and the Constitutional Arrangements Committee, constitutional significance: "arises from an amalgam of considerations, including the importance of the enactment to transcending constitutional questions, the consensus of commentators, and public opinion". ${ }^{91}$ While in 1992, Brookfield observes that the Bill of Rights may "yet acquire the quasiconstitutional status that its long title would lead one to expect for it"92 we later see the Bill of Rights Act has acquired this status in academic literature. ${ }^{93}$ For example, both Joseph and Palmer identify the Bill of Rights Act as a constitutional statute. ${ }^{94}$ Joseph designates the Bill of Rights Act as a constitutional statute describing it as a reform that has "capitalised upon earlier institutional innovations to establish and indigenous constitutional system." "95 In concert with this position, Palmer's article outlining New Zealand's constitutional instruments states that: ${ }^{96}$

The Bill of Rights Act 1990 (NZ) is an example of a statute that is so selfconsciously constitutional that, while s 4 makes clear that other legislation cannot be struck down by its application, s 6 calls for courts to interpret all other statutes consistently with its rights and freedoms, where possible. This reflects the long-held common law disposition to interpret legislation consistently with fundamental principles of law.

\footnotetext{
${ }^{90}$ Claudia Geiringer, "The Dead Hand of the Bill of Rights? Is the New Zealand Bill of Rights Act 1990 a Substantive Legal Constraint on Parliament's Power to Legislate?” (2007) 11(3) Otago Law Review 389.

91 Constitutional Arrangements Committee Inquiry to review New Zealand's existing constitutional arrangements, above $\mathrm{n}$ 1, at 30 quoting Paul Rishworth (ed) The New Zealand Bill of Rights (Oxford University Press, Melbourne, 2002) at [2] footnote 11: "'Constitutional significance' is not bestowed by Parliament or anyone else. It arises from an amalgam of considerations, including the importance of the enactment to transcending constitutional questions, the consensus of commentators, and public opinion. This is why an enactment might evolve into the 'constitutional' category, as the Treaty of Waitangi did in the 1980s".

92 Brookfield "Constitutional Law", above n 32, at 237.

${ }^{93}$ See generally Rishworth, The New Zealand Bill of Rights, above n 91, ch 1; and Butler and Butler The New Zealand Bill of Rights Act: A Commentary, above n 43, at ch 1, 2, and 3.

${ }^{94}$ Palmer "What is New Zealand's constitution", above n 24, at 139, 142-144 and annex.

95 Joseph Constitutional and Administrative Law, above n 3, at 4.

${ }^{96}$ Palmer "What is New Zealand's constitution", above n 24, at 139.
} 
The Executive branch also ascribes the Bill of Rights Act with constitutional status. ${ }^{97}$ For example, the introduction to the Cabinet Manual prepared by the Rt Hon Sir Kenneth Keith includes the Bill of Rights Act as one of the sources of the constitution and the Cabinet guidelines set out specific processes departments must follow to ensure they develop policy consistently with the Bill of Rights Act. ${ }^{98}$ The report of the Constitutional Arrangements Committee records the Bill of Rights Act as one of New Zealand's constitutional milestones, and notes that the Bill of Rights Act is one of the written parts of New Zealand's constitution. ${ }^{99}$

Finally, one of the clearest indicators of the courts' ability to perform constitutional review of legislation under the Bill of Rights Act is accepted by Parliament is the lack of legislative curtailment of this activity. Parliament has proved that it can be extraordinarily reactive in the wake of unwelcome judicial decisions as exemplified by the passing of the Foreshore and Seabed Act 2004 that responded to the decision in Ngati Apa $v$ Attorney-General. ${ }^{100}$ However, the Bill of Rights Act has remained manifestly unblemished by legislative amendment. Section 19 of the Bill of Rights Act is the only section to be amended when it was substituted to refer to the prohibited grounds in the Human Rights Act 1993 rather than the grounds of "ground of colour, race, ethnic or national origins, sex, marital status, or religious or ethical belief" in subs (1), and refer to the Human Rights Act in subs (2). ${ }^{101}$ After the decision in Baigent's case, the Executive referred the matter to the Law Commission for consideration and the Commission concluded: "that there should be no general legislation removing or circumscribing the remedy for breach of the New Zealand Bill of Rights Act 1990, which Baigent's case held to be available." 102

Furthermore, Executive and Legislature action shows consideration of the same approach taken by the courts. For example, reports tabled in the House of Representatives by the Attorney-General under s 7 of the Bill of Rights Act not only apply s 5 but also do so with reference to the courts' decisions in cases such as Moonen

\footnotetext{
${ }^{97}$ See generally Cabinet Office Cabinet Manual 2008 at 1-6; Ministry of Justice The Guidelines On The New Zealand Bill Of Rights Act 1990: A Guide To The Rights And Freedoms In The Bill Of Rights Act For The Public Sector (Wellington, 2004) at Part I; Legislation Advisory Committee Guidelines on Process and Content of Legislation (Wellington NZ, 2001 edition with amendments to full text) at ch 4; and New Zealand Government New Zealand National Universal Periodic Review Report to the Human Rights Council A/HRC/WG.6/5/NZL/1 (9 April 2009).

${ }^{98}$ Cabinet Office Cabinet Manual 2008, above n 96, at 1-6; and CabGuide

$<$ http://cabguide.cabinetoffice.govt.nz/>

99 Constitutional Arrangements Committee Inquiry to review New Zealand's existing constitutional arrangements, above $\mathrm{n} 1$, at 35 and 84 .

${ }^{100}$ Ngati Apa v Attorney-General [2003] 3 NZLR 643 (Māori Land Court).

${ }^{101}$ This amendment took effect on1 February 1994 pursuant to s 145 Human Rights Act 1993.

${ }^{102}$ Law Commission Crown Liability and Judicial Immunity A response to Baigent's case and Harvey v Derrick (NZLC R37, 1997) at 7 [Crown Liability and Judicial Immunity].
} 
(No.1) and Hansen. ${ }^{103}$ The lack of legislative amendment also reflects the reverence, whether ideological or out of political necessity, with which the Bill of Rights Act is regarded by the Executive and Legislature. In fact, we have seen attempts, through a Member's Bills, to see rights added to the Bill of Rights Act in an effort to gain greater legal and constitutional status to better serve those interests. ${ }^{104}$

To conclude, the three branches of government consider the Bill of Rights Act to be part of the New Zealand constitution. From a pragmatic perspective, not only can the courts perform review of legislation under the Bill of Rights Act and this type of review can be characterised as constitutional review because it seeks to ensure that legislation is consistent with constitutional values. This is an evolving role in which the courts have struck a cautious balance to date to ensure that their analysis is consistent with the constitution to maintain the legitimacy of constitutional review of legislation.

\footnotetext{
${ }^{103}$ See Attorney-General Report of the, under the New Zealand Bill of Rights Act 1990 on the Liquor Advertising (Television and Radio) Bill, presented to the House of Representatives pursuant to section 7 of the New Zealand Bill of Rights Act 1990 (2 July 2009) J.4; and Attorney-General, Report of the, under the New Zealand Bill of Rights Act 1990 on the Eden Park Trust Amendment Bill, presented to the House of Representatives pursuant to section 7 of the New Zealand Bill of Rights Act 1990 (8 April 2009) J.4.

${ }^{104}$ See Human Rights (Gender Identity) Amendment Bill (Georgina Beyer MP) and the New Zealand Bill of Rights Act (Property Rights) Amendment Bill (Gordon Copeland MP).
} 


\section{PERFORMANCE OF CONSTITUTIONAL REVIEW}

The challenge to the legitimacy of constitutional review is not limited to challenging the legal authority for that review. ${ }^{105} \mathrm{~A}$ prominent objection to constitutional review of legislation is that it is undemocratic because judges are reviewing and, in some jurisdictions, able to strike down legislation; this activity is seen as contrary to the purpose of a democracy that is intended to see the law and governance of a country reflect the views and beliefs of the public as determined by a representative Parliament. This is often referred to as the "democratic" or "antimajoritarian" objection to constitutional review. This objection is present in the literature even in countries that limit legislative power under their constitution and permit judges to strike down law. ${ }^{106}$

The democratic objection, however, takes an overly simplistic view of democracy and fails to account for the fact that there is democratic value in people being able to use the institutional advantages of impartial decision-making available through the courts to challenge the law and promote change. Constitutional review is a way of generating debate about the effect of policy or laws on the broader public interests or challenging the application of laws that may have a disproportionate effect on minorities or marginalised groups in society. The democratic objection is not born out in the New Zealand context in light of the approach the courts take to constitutional review of legislation under the Bill of Rights Act. This chapter uses the judgments in Hansen to illustrate that the method employed by the courts to perform constitutional review ameliorates the democratic objection to constitutional review.

Constitutional review requires the courts to assess the substance of the law against constitutional standards such as the rights and freedoms in the Bill of Rights Act. This form of review, as observed by Joseph, is distinct from administrative law review because administrative law review is a "review of process and the logic of decision-making". ${ }^{107}$

\footnotetext{
${ }^{105}$ See Kyritsis “Representation and Waldron's Objection to Judicial Review", above n 30, at 733 .

${ }^{106}$ Ekins "The Authority of Parliament", above n 17, at 66.

${ }^{107}$ Joseph Constitutional and Administrative Law, above n 3, at 21.11.
} 
Joseph characterises the five analytical steps of constitutional review as being an inquiry by the courts of: ${ }^{108}$

1. the value or importance of the public purpose the decision-maker seeks to achieve

2. the nature of the interests involved (whether Treaty principles, our international treaty obligation, or our civil and political rights are in issue)

3. the damaging or attenuating effect of the decision on those interests

4. whether the desired public purpose(s) (the ends) could be achieved in less intrusive ways (the means)

5. where the balance of public interest or welfare lies.

These five elements of Joseph's test for constitutional review are constituent elements of the two-stage approach employed for reviewing legislation for consistency with the Bill of Rights Act. In general, there is a two-stage approach applied to assessing legislative provisions for inconsistency with most of the rights in the Bill of Rights Act. ${ }^{109}$ The first stage is to determine whether the legislative provision is inconsistent with a right and, therefore, poses a limit on the right concerned. The second and third elements of Joseph's test, about the nature of the interests and the effect of the legislative provision on those interests, are used to determine whether the legislative provision is a limit on the right. Whether a legislative provision poses a limit on the right involves interpretation of the right, the purpose of the legislative provision concerned, and the effect of that legislative provision on the right. The second stage is to assess whether the limit posed by the legislative provision is justified under s 5 of the Bill of Rights Act. ${ }^{110}$ The first, fourth and fifth elements of Joseph's test are constituent elements of the proportionality analysis that is generally employed to determine whether that limit is a justified limitation on the right under $\mathrm{s} 5$ of the Bill of Rights Act.

New Zealand is not alone is applying a two-step test that is then broken down into elements both Canada and the United Kingdom take a similar approach; for

\footnotetext{
${ }^{108}$ Joseph Constitutional and Administrative Law, above n 3, at 21.11.1. In the 1998 article, there was an additional element at four: whether the decision-maker has diligently taken into account those matters.

${ }^{109}$ There is some debate in both about whether s 5 analysis should be applied to some of the rights contained in the Bill of Rights Act such as s 21 of the Bill of Rights Act which includes the concept of "reasonableness" as part of the right.

${ }^{110}$ See Noort, above n 27, 283 Richardson J.
} 
example, Jowell summarises the courts' inquiry under constitutional litigation as two questions: ${ }^{111}$

First, is there a breach of a fundamental democratic right? If the answer to that question is in the affirmative, the second question asks whether the decision, which appears on its face to subvert democracy, is in fact necessary to preserve it in the interest of a legitimate countervailing democratic value. In addressing these questions the courts will look to the process of justification of the decision and to the inherent qualities of a democratic society.

This following discussion examines how the courts apply the test and its elements in context of Hansen to assess whether the performance of constitutional review of legislation is consistent with the constitution.

\section{A Purposive approach to interpretation and the Bill of Rights Act}

The manner in which courts interpret the right and the legislative provision concerned in performing constitutional review of legislation is not only consistent with New Zealand's constitution but it also refutes critiques of constitutional review. Constitutional review under the Bill of Rights Act has not seen the advent of new and radical interpretative tools that endanger parliamentary sovereignty. When performing constitutional review judges have, however, adopted and used interpretation practices that have developed and strengthened over the last 100 years.

The courts' role has traditionally been described as that of interpretation and application of the law. In order to perform this role, the courts have assembled, using common law, a range of interpretation practices, principles and rules. In New Zealand many of these rules are reflected in the Interpretation Act 1999 (and its predecessor: Acts Interpretation Act 1924). In addition to applying the principle of legality (rather than the doctrine of implied repeal) to give effect to the right, the courts employ the purposive approach drawing on legislative history of a provision and the Act concerned to aid the interpretation of the right and the legislative provision concerned.

The purposive approach has legislative authority in New Zealand by virtue of $\mathrm{s}$ 5(1) of the Interpretation Act 1999 which states: "[t]he meaning of an enactment must

\footnotetext{
111 Jeffrey Jowell "Beyond the rule of law: towards constitutional judicial review" [2000] Public Law 67 at 682 ["Beyond the rule of law"]. For Canadian approach, see generally Peter W. Hogg and Allison A. Bushell, "The Charter Dialogue Between Courts and Legislatures (Or perhaps the Charter of Rights isn't such a bad thing after all)" (1997) 35 Osgoode Hall L.J. 75, at 93-94 ["The Charter Dialogue"]; and Peter W. Hogg, Allison A. Bushell Thornton and Wade K Wright "Charter Dialogue Revisited--Or "Much Ado About Metaphors" (2007) 45 Osgoode Hall LJ 1 at 3 ["Charter Dialogue Revisited"].
} 
be ascertained from its text and in the light of its purpose." This section replaced its lengthier predecessor s 5(j) of the Acts Interpretation Act 1924. However, this interpretative approach has its genesis in the mists of English common law. In Statute Law in New Zealand, Burrows and Carter attribute this approach to Heydon's Case ${ }^{112}$ which was decided in 1584 by the Barons of Exchequer who developed the rule that saw interpretation being informed by the "mischief or defect" that the Act sought to remedy. ${ }^{113}$ The modern articulation of the purposive approach is attributed to Lord Wilberforce in Minister of Home Affairs $v$ Fisher. ${ }^{114}$ The courts rely on an array of interpretation aids for identifying the purpose of a provision including the Long Title and Preamble of the Act, the reports of the select committee, and the debates in the House of Representatives. Despite the frequent use of legislative history as part of the purposive approach, examination of "intention" is treated with great caution when interpreting statutes. For example, Elias CJ cautions against considering legislative intention in determining the meaning of a legislative provision: ${ }^{115}$

The Law Commission recommended against reference to such "intention". The Interpretation Act as enacted follows instead the Law Commission's emphasis on meaning, context and purpose. The principle in s 6 of the Interpretation Act that an enactment must apply to circumstances as they arise underscores the self-evident point that statutes must apply in conditions which may not have been foreseen at the time of enactment. The "very strong and far reaching" obligation of interpretation under s 6 of the New Zealand Bill of Rights Act may also require a meaning to be given to a provision which was not envisaged at the time of its enactment.

Claims that applying the purposive approach undermines the constitution and parliamentary sovereignty are suspect when considered in light of Parliament's endorsement of this approach by enacting it in the Interpretation Act 1999. Furthermore, the purposive approach is intended to give better effect to Parliament's intention when interpreting legislation because it: "is more in line with democratic theory: the courts' avowed task is to cooperate with, rather than frustrate, the will of Parliament." 116

\footnotetext{
${ }^{112}$ Heydon's Case (1584) 3 Co Rep 7a (EWHC Exch).

${ }^{113}$ Burrows and Carter Statute Law in New Zealand, above n 84, at 203-204.

${ }^{114}$ Minister of Home Affairs v Fisher [1980] AC 319.

${ }^{115}$ Hansen, above $\mathrm{n} 8$, at [14] per Elias CJ.

${ }^{116}$ Burrows and Carter Statute Law in New Zealand, above n 84, at 218.
} 
A fulsome understanding of the right forms the essential benchmark against which the importance of the limit is balanced in the proportionality assessment, and such an understanding of the right should be articulated not assumed. ${ }^{117}$ Articulating the nature of the right appears to be entirely consistent with the role of judges to interpret the law; particularly as many of these rights have their genesis in the common law. The purposive approach is essential to the proper interpretation of rights under the Bill of Rights Act. Burrows and Carter frame this approach in pragmatic terms because: "a purely literal construction is scarcely possible given the general nature of its wording." 118 Similarly Rishworth observes that Bills of Rights call for a different approach to interpretation from different statutes because they "use broad and general phrases to denote fundamental moral and political principles, and judges (along with other interpreters) are to give them specification in particular settings."119

For these reasons, the purposive approach has been adopted in New Zealand by the courts for interpreting the rights in the Bill of Rights Act. The purposive approach was endorsed with approval by the Court of Appeal in Noort: ${ }^{120}$

The fundamental rights affirmed in the Bill of Rights Act are to be given full effect and are not to be narrowly construed. Its provisions are to be construed to ensure its objects of protecting and promoting human rights and fundamental freedoms. It is a statute, not an entrenched constitutional document, but it is couched in broad terms requiring interpretation appropriate to those objects.

While Justice Gault's conclusion dissented from that of the majority in Noort, this interpretative statement is applied throughout the majority judgments in Noort and subsequent judgments under the Bill of Rights Act $^{121}$ reinforcing the need for the purposive interpretation of right to include consideration of the "overarching aim" of that right. ${ }^{122}$ New Zealand is not alone in taking the purposive approach to interpreting human rights; it can be seen, for example, in decisions under the Canadian Charter such

\footnotetext{
${ }^{117}$ Compare, Burrows and Carter Statute Law in New Zealand, above n 84, at 224.

${ }^{118}$ Ibid, at 336.

${ }^{119}$ Rishworth, The New Zealand Bill of Rights, above n 91, 43.

${ }^{120}$ Noort, above n 27, at 292 per Gault J (dissenting).

${ }^{121}$ See Richardson P's judgments in $R v$ Jefferies [1994] 1 NZLR 290 (CA) at 299 and $R v$ Te Kira [1993] 3 NZLR 256 (CA) at 271.

${ }^{122}$ See also Rishworth, The New Zealand Bill of Rights, above n 91, at 45.
} 
as: $R v$ Oakes (Oakes), ${ }^{123} R v$ Big M Drug Mart Ltd, ${ }^{124}$ and $R v$ Chaulk (Chaulk). ${ }^{125}$ These decisions under the Canadian Charter are regularly cited in both judgments and academic literature in New Zealand to reinforce the legitimacy of that application of the purposive approach to human rights. ${ }^{126}$

The purposive approach contrasts with that of the originalist approach. The originalist school of thought in the United States advocates that the United States Constitution should be interpreted consistently with the framers original intention. Rishworth observes that this approach has not generated much debate in New Zealand possibly due to the youthful nature of the Bill of Rights Act and a shift in thinking to rights being concepts and that "the guiding principle is the 'purpose of the right', rather than the Parliament's purpose in enacting it."127

Therefore, while the purposive approach does look, in part, to the historical context in which legislation was passed, the primary focus is what it was trying to achieve long term. An example of this approach is evident in the High Court decision in Northern Regional Health Authority v Human Rights Commission, a case involving discrimination against a group not traditionally discriminated against, in which Cartwright J observes: ${ }^{128}$

Understanding of the purpose of legislation designed to promote and protect human rights has evolved since 1989 and the focus cannot, if it ever was in New Zealand, primarily be on remedying adverse outcomes for traditionally disadvantaged groups.

The purposive approach is vital in ensuring that the rights in the Bill of Rights Act remain enduring constitutional values. Burrows and Carter identify four matters as relevant in interpreting rights in the Bill of Rights Act: the scheme of the Bill of Rights Act, parliamentary history, history of the rights themselves, and the international dimension of the right. ${ }^{129}$ Ascertaining and using the purpose of the right goes to the heart of the purposive approach and is also pivotal when examining the effect a limit

\footnotetext{
${ }^{123} R v$ Oakes [1986] 1 SCR 103.

${ }^{124} R$ v Big M Drug Mart Ltd [1985] 1 SCR 295.

${ }^{125} R$ v Chaulk [1990] 3 SCR 1303.

126 See generally Hansen, above n 7; Moonen (No.1), above n 56; Rishworth The New Zealand Bill of Rights, above n 91 at 176-189; and Butler and Butler The New Zealand Bill of Rights Act: A Commentary, above n 43 , at 6.11 .

${ }^{127}$ Rishworth, The New Zealand Bill of Rights, above n 91, at 46-47.

${ }_{128}$ Northern Regional Health Authority v Human Rights Commission [1998] 2 NZLR 218 at 232.

${ }^{129}$ Burrows and Carter Statute Law in New Zealand, above n 84, at 340-343.
} 
has on the right. The decisions of Elias CJ and McGrath $\mathrm{J}$ in Hansen reflect this approach.

There is limited discussion in Hansen about how to determine the meaning of a right; although the method taken suggests ready acceptance of the purposive approach. Elias CJ and McGrath J demonstrate the method with a dedicated discussion in each of their judgments about the right to be presumed innocent as protected by s 25 (c) of the Bill of Rights Act. In contrast, the discussion in the judgments of Blanchard, Tipping, and Anderson $\mathrm{JJ}$ is minimal and usually inferred from their comments about other matters.

In addition to applying the purposive approach, Elias CJ dedicates several paragraphs to describing the analytical approach to defining rights. The meaning of the right is to be "ascertained by reference to the register provided by the New Zealand Bill of Rights Act, viewed in context (including the context provided by the International Covenant)." ${ }^{\prime 130}$ Furthermore, Elias CJ endorses a purposive approach to the right quoting with approval Dickson $\mathrm{CJ}$ in Oakes who identified the following considerations as relevant to the interpretation of rights: ${ }^{131}$

- the character and objectives of the bill of rights itself

- the language chosen

- the historical origins of the concepts underpinning the right

- and, where applicable, the meaning and purpose of related rights and freedoms.

While McGrath J's judgment carefully examines the right to be presumed innocent, it does not provide a discussion about how the meaning of the right should be determined. McGrath J's approach largely reflects that described by Elias CJ and in concluding his discussion of the right, Justice McGrath notes that the "importance of the right to the benefit of the presumption of innocence" as an essential element in considering whether a statutory provision is a justified limitation. ${ }^{132}$

The rights in the Bill of Rights Act have common law and international law heritage and "many in fact have a far longer history than that: many can be traced back to the social philosophy of centuries past." ${ }^{\prime 13}$ Often the historical and international genesis of a right is expressed together. In her judgment, Elias CJ in Hansen notes the

\footnotetext{
${ }^{130}$ Hansen, above $\mathrm{n} 8$, at [18] per Elias CJ.

${ }^{131}$ Ibid, at [20] per Elias CJ quoting Oakes, above n 123, at [28] per Dickson CJ.

${ }^{132}$ Ibid, at [199] per McGrath J.

${ }^{133}$ Burrows and Carter Statute Law in New Zealand, above n 84, at 341.
} 
common law origin of the right to be presumed innocent as articulated in Woolmington $v$ Director of Public Prosecutions ${ }^{134}$ and Viscount Sankey LC's observation in Woolmington that the rule can be modified by statute. ${ }^{135}$ Elias CJ then identifies that this common law rule has been recognised as a human right in international instruments such as article 11(1) of the Universal Declaration of Human Rights and article 14(2) of the International Covenant on Civil and Political Rights (ICCPR) before appearing in $\mathrm{s}$ 25(c) of the Bill of Rights Act and concludes that the Bill of Rights Act enacted it a minimum standard of criminal procedure in $1990 .{ }^{136}$ Likewise, McGrath J discusses the presumption of innocence including its origins in common law, its occupation in the ICCPR and European Convention on Human Rights, and its role as a "core value in the criminal justice system." 137

In examining the purpose of the right to be presumed innocent, Elias $\mathrm{CJ}$ also describes the right to be presumed innocent as a protection against error in criminal process and considers it to be an aspect of fair trial. The Chief Justice draws on the borderless dimension of human rights when defining the nature of the right by quoting the following passage from Justice Brennan of the United States Supreme Court to support the proposition that the right is a protection against error: ${ }^{138}$

There is always in litigation a margin of error, representing error in fact finding, which both parties must take into account. Where one party has at stake an interest of transcending value - as a criminal defendant his liberty this margin of error is reduced as to him by the process of placing on the other party the burden ... of persuading the fact finder at the conclusion of the trial of his guilt beyond a reasonable doubt.

Like Elias CJ, McGrath J identifies the role of the presumption of innocence in criminal procedure as to: "reduce the risk of factual error in a criminal trial resulting in a wrongful conviction." "139 McGrath J also notes Wigmore's statement about the effect this presumption has on a jury's deliberations; it is intended to get them to focus on the evidence and not ascribe significance to the fact that the accused is being prosecuted. ${ }^{140}$

\footnotetext{
${ }^{134}$ Woolmington v Director of Public Prosecutions [1935] AC 462.

${ }^{135}$ Hansen, above $\mathrm{n}$ 8, at [27] per Elias CJ.

${ }^{136}$ Ibid, at [27]-[29] per Elias CJ.

${ }^{137}$ Ibid, at [193]-[199] per McGrath J.

${ }^{138}$ Ibid, at [26] per Elias CJ quoting Justice Brennan of the United States Supreme Court Speiser $v$ Randall (1958) 357 US 513 at $525-526$.

${ }^{139}$ Ibid, at [197] per McGrath J.

${ }^{140}$ Ibid, McGrath J references Wigmore on Evidence (Chadbourn rev 1981), vol 9, [2487].
} 
In Hansen, Elias $\mathrm{CJ}$ and McGrath $\mathrm{J}$ also go beyond the subjective (immediate) purpose of the right reducing the risk of wrongful conviction to the objective (long term) enduring purpose of promoting public confidence in the criminal justice system, namely that the public can be: "confident that innocent people are not convicted, because guilt of criminal charges is determined by independent courts which apply the standard of proof beyond reasonable doubt." ${ }^{141}$ In addition, McGrath J sees the presumption of innocence as a form of constitutional protection that is recognised by the community as a: "protection of the citizen which balances the interests of persons charged against the power and resources of the State as the prosecutor of charges of criminal offending". ${ }^{142}$ Similarly, Elias CJ quotes from Sachs J's judgment in the Constitutional Court of South Africa in $S v$ Coetzee to draw attention to the importance the right to be presumed innocent from a broader perspective; it "serves not only to protect a particular individual on trial, but to maintain public confidence in the enduring integrity and security of the legal system." ${ }^{143}$ It is vital that both the subjective and objective approach to defining the nature of the right is considered because it is material when balancing the right and the limit as part of the proportionality test under s 5 of the Bill of Rights Act.

As demonstrated above, the use of the purposive approach to articulate the meaning of a right can be performed in a way that does not circumscribe Parliament's legislative supremacy. Articulating the genesis of a right not only stamps it with the "enduring" label; it provides an insight into its original necessity and its place in society today - a reminder of the democratic values the right is intended to protect. Burrows and Carter provide an apt caution that such an assessment should not freeze the right in the past because: "the Bill [of Rights Act] must do service in the changing circumstances of the future." ${ }^{144}$ The long title acknowledges that one of the purposes of the Bill of Rights Act was to affirm rights suggesting that Parliament intended to import the history of a right into the Bill of Rights Act and, as noted by Burrows and Carter: "the rights are not conferred by the Act itself, but rather derive from fundamental respect for the human person". ${ }^{145}$ Examining the purpose of the right gives better effect to Parliament's goal in enacting the Bill of Rights Act rather than undermining parliamentary sovereignty.

\footnotetext{
${ }^{141}$ Ibid, at [198] per McGrath J.

${ }^{142}$ Ibid, at [198] per McGrath J.

${ }^{143}$ S v Coetzee (1997) 3 SA 527 at 220 per Sachs J.

${ }^{144}$ Burrows and Carter Statute Law in New Zealand, above n 84, at 342.

${ }^{145}$ Ibid, at 342 .
} 
Purposive approach to interpreting the legislative provision on the right

The courts often apply a more restrictive approach to interpreting a legislative provision if: "the legislation is perceived as threatening certain values which are fundamental to our legal system." ${ }^{146}$ While the meaning of the limit may itself be construed narrowly, the courts do seek to appreciate why Parliament has opted to enact a limit by articulating its public purpose using the purposive approach.

In Hansen the purpose of the Misuse of Drugs Act was used to provide an insight about the end that the provision was seeking to achieve to complement the assessment of the intended effect of the provision. ${ }^{147}$ Blanchard, Tipping, McGrath, and Anderson JJ all locate the public purpose of the reverse onus in s 6(6) of the Misuse of Drugs Act within the broader social issue of illegal drug use and prosecuting offenders. While Tipping $\mathrm{J}$ and McGrath $\mathrm{J}$ deal with the public purpose quickly concluding that it is important; Blanchard and Anderson JJ provide a more detailed account.

Despite the brevity of the descriptions by Tipping and McGrath JJ both the purpose of the Act and the provision are canvassed. For example, McGrath J describes the public purpose as twofold: ${ }^{148}$

First it is to reduce the volume of controlled drugs that come onto the illegal market. Secondly it is to facilitate detection and prosecution of commercial drug dealing behaviour.

McGrath J also notes the context in which the provision sits by connecting it to the objective of repressing illicit dealing in controlled drugs. ${ }^{149}$

The separate judgments of Anderson and Blanchard JJ go into greater detail about the purpose of the Act and the context in which the provision operates by noting the social problem posed by drug use and describing the prosecutorial problems with proving possession for the purposes of drug trafficking as opposed to possession for personal use. For example, in discussing the social problem posed by drugs, Blanchard

\footnotetext{
146 Ibid, at 227.

${ }^{147}$ Compare to Burrows and Carter Statute Law in New Zealand, above n 84, at 219-224. The discussion observes that the purpose of an Act (that is, its effect or the end the legislation is designed to achieve or both) may be of limited assistance when analysing the purpose of a provision.

${ }^{148}$ Hansen, above n 8, at [206]-[207] per McGrath J.

${ }^{149}$ Ibid, at [207] per McGrath J; see also [125] per Tipping J.
} 
$\mathrm{J}$ provides a high level description reflecting on the purpose of the Misuse of Drugs Act: ${ }^{150}$

No-one familiar with life in New Zealand would dispute that the misuse of drugs to which the 1975 Act is directed is a cause of grave social ills and that the trafficking of controlled drugs is an evil. They can cause death and misery for users, who are frequently stimulated to criminal activity under their mindaltering and addictive effects.

Furthermore, both Blanchard and Anderson JJ consider this problem and the "health, safety and economic implications" to be obvious and not requiring great elaboration. ${ }^{151}$ While this seems contrary to the principle that courts should discover rather than assume a purpose; it is worth bearing in mind that the courts are the primary stage in which criminal justice plays out. Blanchard $\mathrm{J}$ then describes the problem the provision is intended to resolve as the challenge faced by prosecutors in establishing that drugs were held for dealing, which carries a higher penalty, as opposed to personal use. Specifically, Blanchard $\mathbf{J}$ notes that it is easier for the prosecutor to prove when the offending is at the extreme ends of the scale, but in the case of equivocal amounts, such as those amounts held by street dealers, it is more difficult to prove that the accused was trafficking the drugs. ${ }^{152}$ Anderson J, unlike Blanchard J, reaches the conclusion after this analysis that: "I see no justification for the proposition which seems to underpin s 6(6) of the Misuse of Drugs Act, namely that because it is difficult for the prosecution to prove an element of a crime it does not have to. That is an unprincipled expedient." 153

Chief Justice Elias' judgment in Hansen does not specifically discuss the public purpose of the provision or the Act beyond briefly noting that the public interest in repressing drug taking is reflected in statutory provisions and commitment of police resources. $^{154}$

As for interpreting the purpose and meaning of the right, the use of the purposive approach to gain an understanding of the purpose of the legislative provision concerned ensures that a balanced consideration of a limit in the proportionality test. This approach to interpretation for the legislative provision can be performed

\footnotetext{
${ }^{150}$ Ibid, at [67] per Blanchard J; see also [273] per Anderson J.

${ }^{151} \mathrm{Ibid}$, at [273] per Anderson J; see also [67] per Blanchard J.

${ }^{152}$ Ibid, at [68] per Blanchard J.

${ }^{153}$ Ibid, at [274] per Anderson J.

${ }^{154}$ Ibid, at [43] per Elias CJ
} 
consistently with the constitution and without undermining Parliament's legislative supremacy. The controversy, arguably, arises not in the interpretation of the limit but when the courts consider whether the objective behind that limit is of value or importance because this assessment involves a value judgment or when the courts seek to interpret the legislative provision consistently with the Bill of Rights Act under s 6 of that Act.

\section{Assessing the effect of the legislative provision on the right}

An assessment of the effect of a legislative provision on the right, under Bill of Rights Act analysis, is usually made in either or both of the following contexts: when determining whether the provision places a limit on the right, or as part of the proportionality test. ${ }^{155}$ While assessing the effect of the provision on the right does not necessitate a purposive approach, there can be differing outcomes to this assessment if the purposive interpretation of the right and the legislative provision is performed too broadly or too narrowly which may have the effect of undermining the law.

While there is limited discussion in Hansen, about how the courts should analyse the effect of a provision on the right, each judgment does assess the effect of $\mathrm{s}$ 6(6) of the Misuse of Drugs Act. Blanchard J's judgment provides some insight into how the courts should approach this assessment: ${ }^{156}$

In a case such as this, when the natural meaning of a legislative provision and the obvious Parliamentary intention coincide, the starting point for the application of the Bill of Rights must be to examine that meaning against the relevant guaranteed right - in this case, s 25(c) - to see if it apparently curtails the right so as to engage the Bill of Rights' interpretive provisions (ss 4, 5 and $6)$.

The meaning and purpose associated with the right plays a pivotal role in this analysis; if the right is construed narrowly with only reference to the subjective effects of the legislative provision concerned in the immediate situation then the damaging or attenuating effect of the provision may be marginalised. In contrast if the right is also defined in terms of the objective purposes then the broader or "distant" effects of the

\footnotetext{
${ }^{155}$ See generally the decisions in Noort, above n 27; and Poumako, above n 57; and Butler and Butler The New Zealand Bill of Rights Act: A Commentary, above $\mathrm{n} 43$, at ch 5; and Rishworth The New Zealand Bill of Rights, above $\mathrm{n}$ 91, at 172-190.

${ }^{156}$ Hansen, above $\mathrm{n} 8$, at [57] per Blanchard J.
} 
limit on the right can also be measured. ${ }^{157}$ The judgments in Hansen characterise the damaging effect of $s$ 6(6) of the Misuse of Drugs Act on the right as the risk for wrongful conviction and the undermining of the right itself. Both of these effects on the right have subjective and objective elements.

Elias CJ, McGrath and Anderson JJ consider the subjective effect of wrongful conviction on an individual as part of their analysis. McGrath $\mathrm{J}$ quotes the following from Dickson $\mathrm{CJ}$ in Oakes to illustrate the serious consequences of criminal conviction: ${ }^{158}$

The presumption of innocence protects the fundamental liberty and human dignity of any and every person accused by the State of criminal conduct. An individual charged with a criminal offence faces grave social and personal consequences, including potential loss of physical liberty, subjection to social stigma and ostracism from the community, as well as other social, psychological and economic harms.

Elias CJ considers that the damaging effect of s 6(6) of the Misuse of Drugs Act is that it permits conviction of those who cannot disprove the presumption and: "who are as likely as not to have no intention of supplying others, but who cannot overcome the persuasive burden". ${ }^{159}$ Anderson $\mathrm{J}$ in the context of discussing the House of Lords decision in $R v$ Director of Public Prosecutions, ex $p$ Kebilene, ${ }^{160}$ states his conclusion in respect of a presumption defence bluntly as meaning: "an accused could be convicted on the strength of suspicion". ${ }^{161}$

In contrast, the judgments of Blanchard and Tipping $\mathrm{JJ}$ focus on the nature of the risk of wrongful conviction and weigh that risk up against other factors. The analysis of risk is subjective because it focuses on the outcomes for an individual. Initially, Blanchard $\mathrm{J}$ looks at how the right is affected in practice and concludes that the risk is more theoretical than real: ${ }^{162}$

I regard that risk [of wrongful conviction] as one which in the vast majority of cases will be more theoretical than real. It is also a risk that can easily be avoided by those whose (unlawful) possession of drugs is genuinely for their

\footnotetext{
${ }^{157}$ See generally the judgments of Elias CJ and McGrath J in Hansen, above $\mathrm{n} 8$.

${ }^{158}$ Hansen, above n 8, at [196] per McGrath J quoting Dickson CJ in Oakes, above n 123, at [29].

${ }^{159}$ Ibid, at [38] per Elias CJ.

${ }^{160} R$ v Director of Public Prosecutions, ex p Kebilene [2000] 2 AC 326.

${ }^{161}$ Hansen, above n 8, at [285] per Anderson J

${ }^{162} \mathrm{Ibid}$, at [80] per Blanchard J.
} 
own use by refraining from acquisition of such quantities as may attract the reverse onus.

This assessment by Blanchard $\mathrm{J}$ focuses on the risk of wrongful conviction for the individual concerned and does not look to the broader effect of the limit on the right itself. ${ }^{163}$ In the context of looking at how the levels for the presumption are set, Tipping $\mathrm{J}$ expresses concern that the fact that the level reflects only the probability of supply increases the risk of wrongful conviction. ${ }^{164}$

Both Tipping and Blanchard JJ make these observations about the risk of wrongful conviction when weighing up whether or not the limit imposed by s 6(6) of the Misuse of Drugs Act is proportionate to the objective to determine if it is a justified limitation under s 5 of the Bill of Rights Act. Yet, both judges reach a different conclusion with Blanchard $\mathrm{J}$ concluding that the provision is justified while Tipping $\mathrm{J}$ concludes that it not. The material difference may be that while Tipping $\mathrm{J}$ characterises the effect of s 6(6) of the Misuse of Drugs Act on the right to be presumed innocent in terms of the risk of wrongful conviction he also introduces an objective element and reaches a different conclusion from Blanchard $\mathrm{J}$ by drawing on the historical values attributed to the right: ${ }^{165}$

From the days of Blackstone that risk has generally been regarded as more acceptable than that of convicting the innocent. To what extent either of these risks are or would actually be manifested is impossible to establish with any numerical precision. The advantage on one side does not necessarily approximate the disadvantage on the other. The number of guilty persons who would not be convicted if the presumption were weaker bears no necessary relationship to the number of innocent persons who would not be convicted for the same reason.

The assessment of the objective effect of the limit often leads the analysis back to the value of the right itself in the course of the proportionality test. For example, McGrath J concludes, after ascertaining the ordinary meaning of s 6(6) of the Misuse of Drugs Act and discussing the nature of the right, ${ }^{166}$ that it is inconsistent with s 25 (c) of

\footnotetext{
${ }^{163}$ Ibid, at [80] per Blanchard J.

${ }^{164}$ Ibid, at [138] per Tipping J.

${ }^{165}$ Ibid, at [132] per Tipping J; see also Tipping J's discussion at [89], [100], [132], [134], [137] and [138].

${ }^{166}$ Ibid, at [196]-[199] per McGrath J.
} 
the Bill of Rights Act without reference to the damaging or attenuating effect that $\mathrm{s}$ 6(6) may have on the right. ${ }^{167}$ Later in the judgment McGrath J, like Blanchard and Tipping JJ, addresses the effect of s 6(6) of the Misuse of Drugs Act on the right to be presumed innocent when considering whether the limit is a proportionate one and focuses on the overall effect on the right: ${ }^{168}$

Indeed it nullifies that right in relation to the mental element of the offence. The offence concerned is a very serious one, being punishable by a maximum term of eight years' imprisonment. The high degree of social importance of the protected right, which is not in dispute, is engaged.

This quote demonstrates that McGrath J progresses from the subjective effect of the limit on the right (nullifying the mental element) to the objective effect on the right itself (social importance of the right is engaged) in the course of his analysis.

Anderson J, after making general statements about how the court should apply the Bill of Rights Act, describes the effect of s 6(6) of the Misuse of Drugs Act in objective terms as replacing the presumption of innocence with a "presumption of guilt" pointing to potential erosion of the right given drug trafficking is not the only type of criminal offending in which the prosecution may have problems proving intent or the requisite mental element. ${ }^{169}$ Anderson J concludes that s 6(6) of the Misuse of Drugs Act appears to conflict with s 25(c) of the Bill of Rights Act.

Elias CJ, in the course of discussing the types of ends that may justify a limit on the right to be presumed innocent and the public interest in repressing drug taking, concludes: "[e]xclusion of the right to be presumed innocent in respect of such crimes would undermine the right enacted as a minimum standard". ${ }^{170}$

A purposive interpretation of the right and the legislative provision concerned are pivotal in ensuring that the full effect of the legislative provision on the right can be robustly understood in terms of both its subjective and objective effect. This approach also ensures that the courts are giving proper effect to the law enacted by Parliament in reconciling seemingly inconsistent legislative provisions (the right and the limit) while maintaining the constitutional importance of the values protected by the Bill of Rights Act. The purposive approach is not without its weaknesses and the courts have to be

\footnotetext{
${ }^{167}$ Ibid, at [202] per McGrath J.

${ }^{168}$ Ibid, at [225] per McGrath J.

${ }^{169}$ Ibid, at [269] per Anderson J.

${ }^{170}$ Ibid, at [43] per Elias CJ.
} 
careful in applying this interpretive approach to ensure comity is maintained between the courts and Parliament.

\section{B Challenges for the purposive approach in relation to the Bill of Rights Act}

The purposive approach to interpretation is not a complete answer to ensuring that the courts perform constitutional review consistently with the constitution. Legitimacy issues still arise for the courts in the manner they interpret rights and limits. Not only must the courts delve into the policy domain to gain information about the respective purposes of the right and the limit but there is the risk that the courts will extend, or diminish, a right; give that right a different status; attribute a provision with a purpose that Parliament did not intend; or define the legislative provision concerned too narrowly. This section examines some of these challenges and also makes some observations for alternative approaches.

\section{$1 \quad$ Evidence of purpose}

In order to assess the public purpose of a legislative provision, judges need to have an appreciation of the policy reasons on which Parliament based its decision. Judges have not been involved in the policy process, heard public submissions, or participated in the debates in the House of Representatives; therefore, they are reliant on the arguments made by the parties to the proceedings about the public purpose of the provision. In some situations, however, judges will be very familiar with the issues - particularly when the issues relate to criminal proceedings, as is the case in Hansen.

In Hansen the Crown sought to introduce a new form of evidence to assist the courts in defining the purpose of the limit: legislative fact. Legislative fact is the term used to describe the information pertaining to the nature of the problem; this information may not be recorded as part of legislative history of a Bill because they were issues addressed in briefings to the responsible Minister that were not of interest during the progress of the Bill through the House. Anderson J describes legislative fact as: "material goes to the content of law and determination of policy, rather than to determination of facts that are in issue in the particular case." ${ }^{171}$

The form legislative fact may take will vary according to the legislative provision in question, Elias CJ summarises the nature of the legislative fact in Hansen as: ${ }^{172}$

\footnotetext{
${ }^{171}$ Ibid, at [230] per Anderson J.

${ }^{172}$ Ibid, at [50] per Elias CJ.
} 
... evidence from police officers and other persons with knowledge relating to drug trafficking and use in New Zealand. This evidence apparently included unpublished material, some said to be of a confidential nature, concerning patterns in the supply and use of cannabis in New Zealand and the policies and strategies of law enforcement authorities in combating illicit drug supply.

The Crown sought the leave of the Supreme Court to introduce this evidence but all the judges declined to receive it because this evidence had not been considered in the earlier proceedings and the appellant challenged its late introduction of the evidence on that ground. Elias CJ, Blanchard J, Tipping J, and McGrath J did, however, express a willingness to hear this sort of evidence if it is available and submitted in accordance with procedure rules. ${ }^{173}$ In addition, McGrath $\mathrm{J}$ states that such material would not be subject to the same requirements of the rules of evidence as adjudicative fact but can be admitted to the court through judicial notice. ${ }^{174}$

While the judgments in Hansen do not discuss the specific value of legislative fact, the type of evidence adduced as legislative fact would be helpful in illuminating the purpose behind a legislative provision to provide context for why specific policy positions are adopted. The fact that the Crown sought to adduce this evidence suggests that the Crown did not have serious concerns that judicial scrutiny of this information may undermine the constitution or parliamentary sovereignty.

Judicial discussion of the nature of a right is essential

The judgments of Blanchard, Tipping, and Anderson JJ in Hansen make passing reference to the right to be presumed innocent. For example, the need to examine the right itself can only be inferred from Blanchard J's acknowledgment of Richardson J's approach in Noort ("the significance in the particular case of the values underlying the Bill of Rights Act"); ${ }^{175}$ and Tipping J's summary of his approach to the s 5 analysis in this case ("Ascertain whether the meaning is apparently inconsistent with a relevant right or freedom"). ${ }^{176}$

The absence of discussion about the nature of the right in the judgments of Blanchard $\mathrm{J}$ and Tipping $\mathrm{J}$ is troubling because it is imperative that the nature of the interests that the right seeks to protect are clear before determining whether a limit on a

\footnotetext{
${ }^{173}$ Ibid, at [9] and [50] per Elias CJ; at [50] per Blanchard J; at [132]-[133] per Tipping J; and at [230][232] per McGrath J.

${ }_{174}$ Ibid, at [230] per McGrath J.

${ }^{175}$ Ibid, at [64] per Blanchard J quoting Noort, above n 27, at 283 per Richardson J.

${ }^{176}$ Ibid, at [92] per Tipping J.
} 
right is justified. In this case, it appears that the discussion of the right is absent because the significance of the right is assumed given the cases that have gone before, or they rely on the discussion by Elias $\mathrm{CJ}$ and McGrath $\mathrm{J}$ of the right. Burrows and Carter rightly emphasise that it is important for the court to use the purposive approach to discover rather than assume the purpose of the right. ${ }^{177}$

While Blanchard J, when describing recent House of Lord's decisions states that: "the presumption of innocence is a fundamental component of the absolute right to a fair trial" $" 178$ the lack of detail in Blanchard J's judgment about the nature of the right leaves the analysis seeming incomplete because it does not engage with either the subjective or objective aspects of the right. If judges decide to rely on their colleagues or previous cases (in the interests of brevity) to reflect their assessment of the nature of the right then this should be stated in their judgment.

In addition to considering the nature of the right it is crucial that the assessment of the effect of a legislative provision on a right considers both the subjective and objective aspects of the right. While the subjective effect of a provision on the right is important to determine whether the provision does limit the right; an appreciation of the objective effect is essential in determining the long-term effect on the right and whether the limit is a proportionate response and, therefore, justified under s 5 of the Bill of Rights Act. It is essential because the right not only protects the individual but is also a reflection of social and philosophical values about how the law should apply to everyone. Focusing merely on the immediate subjective effect of the right ignores the ambulatory nature of the Bill of Rights Act and may, unnecessarily, constrain its application. The courts' practice of looking to the objective effect of the right is consistent with the purposive approach to interpreting rights and, along with using the scheme of the Act and the heritage of the right concerned to interpret the effect of the right, does not undermine parliamentary sovereignty but seeks to give full effect to the Bill of Rights Act.

Altering the application of the Bill of Rights Act to a right

Those concerned with judicial encroachments on parliamentary sovereignty would be well placed to draw attention to the danger of the courts giving some rights a higher status by, for example, determining that a right not be subject to 5 of the Bill of

\footnotetext{
${ }^{177}$ Burrows and Carter Statute Law in New Zealand, above n 84, at 224.

${ }^{178}$ Hansen, above n 8, at [66] per Blanchard J.
} 
Rights Act. ${ }^{179}$ Chief Justice Elias in Hansen concludes that the right to be presumed innocent under s 25(c) of the Bill of Rights Act is an unqualified right - her conclusion is worth recording in full: ${ }^{180}$

The presumption of innocence is unqualified in the International Covenant on Civil and Political Rights, which the New Zealand Bill of Rights Act affirms. Moreover, while the International Covenant expressly permits restrictions on rights such as freedom of thought, conscience and religion and freedom of expression, and indicates the basis upon which such limitations can be made, no such licence is given in relation to the rights to fair trial and to be presumed innocent. It seems well arguable, from the otherwise unaccountable absence in the International Covenant of any register of values against which limitations can be considered, that these rights cannot be restricted as a matter of international obligation, although they may be subject to derogation in emergencies. Whether or not that view is correct in international law, the same effect in my view follows from the nature of the right contained in s 25(c) of the New Zealand Bill of Rights Act.

In reaching this conclusion the Chief Justice rejects the approach taken by the European Court of Human Rights under the European Convention on Human Rights; namely, that the right is not absolute and that a reverse onus is acceptable if there is a legitimate aim and the means are reasonably proportionate to a legitimate aim. ${ }^{181}$ This approach of Elias CJ to the right suggests that a limit on the right to be presumed innocent cannot be justified under s 5 of the Bill of Rights Act. However, while Elias CJ considers the right to be presumed innocent to be unqualified and, as such, any restriction amounts to denial of the right; ${ }^{182}$ the Chief Justice does "raise some matters that will require consideration in a case where s 5 is in issue." ${ }^{183}$ While this seems contradictory because the discussion relates specifically to the right to be presumed innocent rather than generally to the application of s 5; it appears that the distinguishing feature is the criminal context in which the limit appears and that limits in the regulatory context, in some situations, may be able to be justified.

\footnotetext{
${ }^{179}$ See generally Taunoa \& Ors v Attorney-General \& Anor [2006] NZSC 95; and Taunoa \& Ors v Attorney-General [2007] NZSC 70.

${ }^{180}$ Hansen, above n 8, at [36] per Elias CJ see also [7], [28], [37] and [38] per Elias CJ.

${ }^{181}$ Hansen, above $\mathrm{n} 8$, at [35] and [38] per Elias CJ.

${ }^{182}$ Ibid, at [37]-[39] per Elias CJ.

${ }^{183}$ Ibid, at [41] per Elias CJ.
} 
In commenting that some rights and freedoms are able to be subject to justified limits, Anderson $\mathrm{J}$ also makes the following point when comparing the right to be presumed innocent to that of the right to a fair trial: ${ }^{184}$

The right to a fair trial is another example. Whether in a particular case errors of law, or procedural deficiencies or other aberrations, do or do not render the trial unfair is a matter of degree and judgment. But should a trial properly be stigmatised as unfair, s 5 could not be invoked to redeem it. It is also fairly arguable that the burden of persuasion carried by the prosecution in criminal cases is so integral to a fair trial that no relaxation or reversal of it can be justified.

Without discussing the interests underpinning the right to be presumed innocent Anderson J does, however, conclude that s 6(6) of the Misuse of Drugs Act appears to be in conflict with s 25(c) of the Bill of Rights Act unless it can be redeemed by s 5 of the Bill of Rights Act. ${ }^{185}$

The issue of whether s 5 of the Bill of Rights Act should be applied to all rights, including those that contain internal modifiers or that are "unqualified" is still being debated. For example, for a right with internal modifiers (such as "unreasonable") the threshold for establishing a breach of the right could be lower and the threshold for justification could be higher. Another alternative may be to apply s 5 to all rights but vary the intensity of review according to the nature of the right and the seriousness of the infringement the limit imposes on the right. ${ }^{186}$

\section{$4 \quad$ Scope of the right}

It is vital that the right is interpreted separately from the legislative provision concerned to prevent the scope of the right being inadvertently restricted. Elias CJ presents a timely warning to this effect in Hansen: ${ }^{187}$

The first question is the interpretation of the right. In ascertaining the meaning of the right, the criteria for justification are not relevant. The meaning of the right is ascertained from the "cardinal values" it embodies. Collapsing the

\footnotetext{
${ }^{184}$ Ibid, at [264] per Anderson J.

${ }^{185} \mathrm{Ibid}$, at [269] per Anderson J.

186 Julian Rivers "Proportionality and Variable Intensity of Review" (2006) 65(1) Cambridge Law Journal 174 at 195-201.

${ }^{187}$ Hansen, above n 8, at [21]-[23] per Elias CJ.
} 
interpretation of the right and the s 5 justification is insufficiently protective of the right.

It appears that the Chief Justice is cautioning against defining the nature of the right in light of the limit in issue, as this would have the effect of reading down the right. The Chief Justice's warning has significant merit; the right should be read free of the limit because the assessment of the merits of the limit should be carried out as part of the proportionality analysis under s 5 of the Bill of Rights Act. Furthermore, defining the nature of the right in light of the limit would place a difficult burden on the applicant to prove a negative (namely, that the right is not intended to cover the situation presented in a limit).

Burrows and Carter describe the Court of Appeal decision in Noort as having held that "the competing requirements of both Acts could be reconciled by reading down the Bill of Rights provision so as to allow legal consultation by telephone only." 188 In this situation, the right has not, arguably, been read down but it is a recognition that it applies differently in different contexts and a person may only be able to get limited access to the right when the limit is justified; but this is the outcome of the assessment of the interests of both the right and the provision concerned rather than a redefinition of the right itself. The right has not been interpreted to exclude a specific set of situations in which it was not intended for the right to apply. This approach preserves the values and interests the right itself seeks to protect; relying on sections 5 and 6 of the Bill of Rights Act to be the mediator for the current social and political values.

\section{Interpretation and section 6 of the Bill of Rights Act}

Section 6 of the Bill of Rights Act states that: "Wherever an enactment can be given a meaning that is consistent with the rights and freedoms contained in this Bill of Rights, that meaning shall be preferred to any other meaning." Section 6 of the Bill of Rights Act offers the most potential to undermine Parliament because, theoretically, the courts could adopt a meaning that is consistent with the Bill of Rights Act but is inconsistent with the purpose and the meaning of the legislative provision concerned.

A variety of approaches to s 6 of the Bill of Rights Act are evident across case law with the decisions in Noort, Moonen (No.1) and Hansen most commonly referred to in both the case law and commentary about the application of s 6 of the Bill of

\footnotetext{
${ }^{188}$ Burrows and Carter Statute Law in New Zealand, above n 84, at 368.
} 
Rights Act. These approaches generally take one of the following three views about the application of s 6:

- apply s 6 as a complementary interpretation principle (for example, if the meaning of the legislative provision is ambiguous then the provision should be given a meaning that is consistent with the Bill of Rights Act) ${ }^{189}$

- apply s 6 as a step in the analysis (for example, if the provision is an unjustified limitation on the right then $\mathrm{s} 6$ is to be applied after s 5 of the Bill of Rights Act and before s 4 of the Bill of Rights Act) ${ }^{190}$

- apply s 6 as both an interpretation principle and a step in the analysis. $^{191}$

Commentary about which approach Hansen endorses also varies, for example, Petra Butler assesses that both approaches apply ${ }^{192}$ while Wilberg contends that the decision in Hansen advocates for s 6 to apply only after the s 5 analysis has been completed and that potential interpretations that would constitute justified limitations also be considered under s 6 of the Bill of Rights Act. ${ }^{193}$ Both commentators, however, note that Hansen does not provide a conclusive pronouncement of how to apply s 6 of the Bill of Rights Act and that the Supreme Court leaves this as an open question and acknowledged that different factors in each case will have an effect on how it should be applied. ${ }^{194}$ Regardless of where or how in the analysis the courts apply s 6 of the Bill of Rights Act; it needs to be performed consistently with the constitution: in a way that does not frustrate the will of Parliament. ${ }^{195}$

The use of s 6 as an interpretation principle is unlikely to undermine the constitution if that interpretation is consistent with the purpose of the legislative provision concerned because it seeks to reconcile Parliament's purpose in enacting both

\footnotetext{
${ }^{189}$ See for example: Noort, above n 27, at 272 per Cooke P, at 294-296 per Gault J (dissenting), Hansen, above n 8, at [89] per Tipping J, at [179] per McGrath J, and [266] per Anderson J; and Petra Butler "Student Companion $R v$ Hansen [2007] NZSC 7" at 47 ["Student Companion $R v$ Hansen"].

${ }^{190}$ See for example: Noort, above n 27, at 284 per Richardson J; Moonen (No.1), above n 56, [17]-[19] per Tipping J; Hansen, above n 8, at [60] - [61] per Blanchard J, at [91] per Tipping J, at [179] and [190] per McGrath J, and [266] per Anderson J; Hanna Wilberg "The Bill of Rights and other enactments" (2007) New Zealand Law Journal 112 at 112-114; P Butler "Student Companion $R v$ Hansen", above $n$ 189 , at 48 .

${ }^{191}$ Hansen, above $\mathrm{n}$ 8, at [89]-[91] per Tipping J; and P Butler "Student Companion $R v$ Hansen", above n 189 , at $47-48$

192 P Butler "Student Companion $R$ v Hansen", above n 189, at 47-48.

${ }^{193}$ Wilberg "The Bill of Rights and other enactments", above n 190, at 113.

${ }^{194}$ P Butler "Student Companion $R$ v Hansen", above $\mathrm{n}$ 189, at 48; and Wilberg "The Bill of Rights and other enactments", above n 190, at 112-113.

${ }^{195}$ Justice and Law Reform Committee Final Report, above n 86, at 3.
} 
the right in the Bill of Rights Act and the legislative provision concerned. This approach is based on the assumption that Parliament does not intend to breach the Bill of Rights Act, and would only do so explicitly. Furthermore, this approach preserves the position of Parliament as ultimate lawmaker and is consistent with the restriction placed on the courts when performing constitutional review by s 4 of the Bill of Rights Act.

In the cases where the legislative provision concerned results in a limit on a right the constitutional issues become more complex. Commentators have attributed Hansen with concluding that if a limit is justified then there is no recourse to s 6 after analysis under s 5 of the Bill of Rights Act. ${ }^{196}$ This approach is uncontroversial from a constitutional perspective because it shows deference for Parliament's selected approach to the policy matter and objective the legislative provision intends to achieve.

The application of s 6 of the Bill of Rights Act to a limit that has been found to be unjustified, as identified in Hansen, poses a more controversial question because it involves the courts looking for an alternative interpretation of the legislative provision despite the fact that the initial interpretation does not support a natural meaning consistent with the Bill of Rights Act. In relation to this assessment, Petra Butler notes that the decision in Hansen requires that: ${ }^{197}$

To be legitimate the meaning must be "tenable" ... or "genuinely open"... If there is such a tenable, BORA consistent meaning then $\mathrm{s} 6$ requires it to be adopted. If, however, the provision is only reasonably capable of bearing a meaning inconsistent with BORA this has to be adopted whether or not it places a justified limit on a right (s 4 BORA).

The post-section 5 analysis of a legislative provision could be seen as a way of the courts trying to reconcile a constitutional statute and a legislative provision to give proper effect to the law and is prefaced on the assumption that Parliament does not intend to enact laws that are inconsistent with the Bill of Rights Act. In this context the application of s 6 of the Bill of Rights Act almost has a remedial quality that seeks to give better effect to the right concerned. In applying s 6 after s 5 of the Bill of Rights Act, the courts need to guard against substituting a new meaning that is inconsistent with the purpose of the provision. For example, if the courts identified an alternative

\footnotetext{
${ }^{196}$ Hansen, above n 8, at [91] per Tipping J, at [191] per McGrath J, and [269] per Anderson J; and P Butler "Student Companion $R v$ Hansen", above n 189, at 47.

${ }^{197}$ P Butler "Student Companion $R$ v Hansen", above n 189, at 48.
} 
option as part of the proportionality analysis that is consistent with the purpose of the legislative provision concerned and it is a meaning that is "tenable" or "genuinely open" to the courts then adopting this meaning, depending on the facts of the case, may be acceptable so long as it does not (in effect if not in form) contravene s 4 of the Bill of Rights Act.

Webb observes that the courts have, to date, taken a conservative approach to $\mathrm{s}$ 6 of the Bill of Rights Act in relation to review of legislation: "It is also clear though, that the Supreme Court, unlike its United Kingdom counterpart, will not use section 6 to subvert the clear language of section 4." Given the risk to the constitution of any other approach, the current approach of the courts in relation to review of legislation is commendable.

\section{$6 \quad$ Concluding observations}

The application of the purposive approach and interpretation principles to the Bill of Rights Act by the courts does not undermine the constitution or frustrate the will of New Zealand as represented by Parliament through:

- interpreting and applying the legislative provisions too narrowly so as to, in effect, render it void

- substituting a meaning that is inconsistent with the clear meaning of the legislation

- supplementing the legislation to fill a "gap" in the law in such a way as to render the legislative provision ineffectual.

Burrows and Carter also rightly identify that this approach is not without dangers but conclude that the overall outcome is beneficial because "it produces a commonsense approach to interpretation that tries to attain the ends that the frames of the Act had in view." 198 The courts use of the purposive approach and other the interpretation principles in constitutionally reviewing legislation are not encroaching on Parliament's domain by making or unmaking laws, or undermining legislation by substituting interpretations that are inconsistent with the purpose of those provisions. The courts must continue, however, to be vigilant and avoid interpreting rights or legislative provisions in a way that would compromise the constitution, especially when applying s 6 of the Bill of Rights Act to legislative provisions that are unjustified limits.

\footnotetext{
${ }^{198}$ Burrows and Carter Statute Law in New Zealand, above n 84, at 229.
} 


\section{Proportionality Analysis}

The distinguishing feature of constitutional review of legislation is that the courts review the substance of the law; this gives rise to the critique that in performing this analysis the courts are assessing policy and are straying into the domain of Parliament and the Executive. To assess whether a limit is justified under the Bill of Rights Act the courts have employed a proportionality test. ${ }^{199}$ Joseph describes the proportionality test as a defining feature of constitutional review: ${ }^{200}$

Constitutional review calls for evaluation of the harm caused by the decision and the value or importance of the public purpose the decision-maker seeks to achieve. Each of the new grounds varies slightly in method: judicial review based on the Bill of Rights Act is entirely contents-based and substantive....

There are three aspects of the proportionality test that could be described as encroaching on Parliament's domain, the assessment of: the importance of the public purpose of the limit; whether the limit is the least intrusive option; and where, ultimately, the balance of public interests lies (with the right or with the limit). Each of these aspects of the analysis requires the courts to assess Parliament's decision in enacting the limit. In recognition of the respective constitutional roles of the judiciary and the legislature, and the need to ensure comity between these branches of government the courts may apply judicial deference or restraint when making an assessment. Before examining how the courts apply the proportionality test using the Supreme Court decision in Hansen it is helpful to summarise the test and the judicial approach to deference to provide context.

The proportionality test under s 5 of the Bill of Rights Act draws on the test articulated by the Canadian Supreme Court in Oakes. For example, in Hansen the majority of judges referred to Oakes as being instructive for the justification analysis with Elias CJ summarising the test in the following terms: ${ }^{201}$

Where $\mathrm{s} 5$ is however in issue because an enactment inconsistent with the right, properly interpreted, is sought to be justified, the approach taken by the Supreme Court of Canada in $R v$ Oakes and the cases which have followed it is

\footnotetext{
${ }^{199}$ For the purposes of this paper a "limit" is a legislative provision that is inconsistent with a right or freedom in the Bill of Rights Act.

${ }^{200}$ Joseph "Constitutional Review Now", above n 3, at 91.

${ }^{201}$ Hansen, above n 8, at [42] per Elias CJ; [64] per Blanchard J; [103] and [120] per Tipping J; and [185] per McGrath J.
} 
helpful. The objective sought to be achieved by the limiting provision must be of sufficient importance to warrant infringement of a fundamental human right. The limitation must be no more than is reasonably necessary to achieve the purpose. The objective against which a provision is justified cannot be wider than can be achieved by the limitation of the right.

From the outset, judges acknowledged that the proportionality analysis under the Bill of Rights Act would necessarily involve analysis of public policy and require some value judgements. While the making of value judgements could been seen as a stumbling block, Richardson J, in Noort, notes that: "a great deal of helpful case law in other jurisdiction as to the principled bases on which Courts ought to proceed in making their assessment under the section." ${ }^{202}$ Such analysis is not, however, without boundaries. Later in Quilter, Thomas J's dissenting judgment offered a warning about venturing too far into policy analysis when recognising that the current law does not support the plaintiff's desired outcome: ${ }^{203}$

Inevitably the jurist is led into areas of policy, such as the timing of any change to the law, the method by which the law should be changed, and the general acceptance or receptiveness of the community to any such law change. At once, the jurist will appreciate that he or she has strayed beyond the bounds of legal inquiry into the foreign territory of "political" policy.

The issues Thomas $\mathrm{J}$ identifies above are largely strategic policy issues about the political will and desirability of change, not what form that change should take. While Thomas J's judgment was dissenting, the judges all agreed, rightly or wrongly, that the issue of gay marriage was one that should be left to Parliament and could not be reconciled with the existing law using s 6 of the Bill of Rights Act.

Tipping $\mathrm{J}$ observes in Moonen (No1) that the final assessment about whether a limitation is justified is one which: "the Court is obliged to make on behalf of the society which it serves and after considering all the issues which may have a bearing on the individual case, whether they be social, legal, moral, economic, administrative, ethical or otherwise." ${ }^{204}$ When discussing the application of this element of the Oakes test in New Zealand, Rishworth draws attention to Justice Tipping's comments in

\footnotetext{
${ }^{202}$ Noort, above n 27, at 283 per Richardson J.

${ }^{203}$ Quilter, above n 55, at 546 per Thomas J (dissenting).

${ }^{204}$ Moonen (No.1), above n 56, at [18] per Tipping J.
} 
Moonen (No.1) that this element largely involves a value judgment by the courts on behalf of society before noting that " $[\mathrm{t}]$ he touchstone for the s.5 inquiry - freedom and democracy - is not discussed." 205 Tipping J's judgment in Hansen does, however, aptly respond to such a critique.

The test applied in New Zealand is akin to that applied in the United Kingdom where the proportionality test has also adopted for assessing the consistency of legislation with human rights. Jowell in his article about the approach in the United Kingdom identifies, after noting salient decisions, the proportionality test as the touchstone of constitutional review ${ }^{206}$ and identified it as a fourfold test: ${ }^{207}$

Proportionality involves a sophisticated four stage process, asking the following questions:

(1) Did the action pursue a legitimate aim?

(2) Were the means employed suitable to achieve that aim?

(3) Could the aim have been achieved by a less restrictive alternative?

(4) Is the derogation justified overall in the interests of a democratic society?

This fourfold test contains a carefully constructed set of criteria which are designed to ensure that a prima facie violative of a fundamental democratic right is not lightly sanctioned.

Similarly, Wilberg, in discussing the decision in Hansen, summarises the proportionality test employs four factors to been weighed up but she arranges them differently: ${ }^{208}$

on the one hand,

- the importance of the right in the relevant context and

- the severity of the limit on the right;

on the other hand,

- the importance of the objective in the relevant context and

- the effectiveness of the limit in serving the objective, compared to the effectiveness of any available alternatives.

In formulating the elements of constitutional review, Joseph draws on the judgment of Richardson $\mathrm{J}$ in Noort about the application of s 5 as a matter of weighing

\footnotetext{
${ }^{205}$ Rishworth The New Zealand Bill of Rights, above $\mathrm{n}$ 91, at 185.

${ }^{206}$ Jowell "Beyond the rule of law", above n 111, at 678-681.

207 Jowell "Beyond the rule of law", above n 111, at 679.

${ }^{208}$ Wilberg "The Bill of Rights and other enactments", above n 190, at 115.
} 
various different interests, ${ }^{209}$ and the following three elements reflect the proportionality test:

- the value or importance of the public purpose the decision-maker seeks to achieve

- whether the desired public purpose(s) (the ends) could be achieved in less intrusive ways (the means)

- where the balance of public interest or welfare lies. ${ }^{210}$

While the proportionality analysis under the Bill of Rights Act could be considered more akin to an art rather than a science given there are many different descriptions of the test, however, the test is in essence: whether the limit is a proportionate response to a problem given the constitutional significance of the right concerned. $^{211}$ In some situations the court may show deference to Parliament because the nature of the issue places the final call within Parliament's domain; this is another way the courts seek to maintain comity with Parliament. ${ }^{212}$

The crux of the concern about judges assessing public policy under s 5 of the Bill of Rights Act appears to be linked to an apprehension that they may go beyond the assessment and substitute their own view for that of Parliament's position. The separate judgments in Hansen demonstrate a ready awareness of this concern and that the substitution of views would encroach of the decision-making domain of Parliament. For example, in Hansen, Tipping $\mathrm{J}$ notes that such encroachment is something the judiciary guards against: ${ }^{213}$

The courts' function is not immutably to substitute its own view for that of the legislature. If the court agrees with the legislature that the limit is justified, no further issue arises. If the court does not agree, it must nevertheless ask itself

\footnotetext{
${ }^{209}$ Joseph "Constitutional Review Now", above n 3, at 125.

${ }^{210}$ Joseph Constitutional and Administrative Law, above n 3, at 21.11.1. In the 1998 article, there was an additional element positioned as number four: whether the decision-maker has diligently taken into account those matters.

211 See Rabinder Singh QC "Interpreting Bills of Rights" 29 Statute L Rev 82; and Comella "The European model of constitutional review", above n 34. For example, Robert Alexy in "Balancing, Constitutional Review, and Representation", above n 35, designs a Weight Formula for the proportionality test to balance competing interests in cases, and describes constitutional review as "an expression of the priority or superpriority of constitutional rights over and against parliamentary legislation."

${ }^{212}$ This is sometimes referred to as a "margin of appreciation" in which the courts will not intervene with Parliament's decision. Margin of appreciation is generally used when discussing the approach taken by the European Court of Human Rights in recognition of the fact that the different cultures of the member States will require a degree of deference or restraint because the effect of the policy on different cultures may best understood by domestic Parliament (depending on the circumstances).

${ }^{213}$ Hansen, above $\mathrm{n} 8$, at [123] per Tipping J.
} 
whether the legislature was entitled, to use Lord Hoffmann's word, to come to the conclusion under challenge. It is only if Parliament was not so entitled that the court should find the limit to be unjustified.

Tipping $\mathrm{J}$ is careful to recognise the role of Parliament in setting the policy, and yet is transparent and practical about the fact that courts cannot make a sensible analysis under s 5 without reference to policy. In essence, judicial deference or restraint is shown to Parliament because of its democratic mandate to govern and determine policy and the law.

There is no bright line test for when deference or restraint should be shown, or to what extent it affects the analysis in a case. The courts, as observed by Anderson J in Hansen, are sensible to the fact that the constraints of judicial process on making a fulsome inquiry may mean that the courts have to show judicial deference to Parliament in some circumstances. ${ }^{214}$ The decision in Hansen offers some insight into how judicial deference or restraint is applied. As identified by Tipping $\mathrm{J}$ in Hansen the challenge comes in getting the balance right between the role of Parliament in democratically setting the limit, and the judicial role in upholding "rights and freedoms and not to allow them to be limited otherwise than on a convincing basis". ${ }^{215}$ In his judgment Tipping $\mathrm{J}$ offers a figurative and helpful description about the relationship:

The courts' view may be that, in order to qualify, the limitation must fall within the bull's-eye. Parliament's appraisal of the matter has the answer lying outside the bull's-eye but still on the target. The size of the target beyond the bull's-eye will depend on the subject matter. The margin of judgment or discretion left to Parliament represents that area of the target outside the bull'seye. Parliament's appraisal must not, of course, miss the target altogether. If that is so Parliament has exceeded its area of discretion or judgment. ...The courts' job is to delineate the size of the target and then say whether Parliament's measure hits the target or misses it. ${ }^{216}$

For ease of reference this description will be called: "Tipping's target metaphor". Tipping $\mathrm{J}$ also uses a conceptual spectrum to define the potential limits of the courts proportionality analysis under s 5 of the Bill of Rights Act with "major political, social or economic decisions" at one end and "matters that have a substantial

\footnotetext{
${ }^{214}$ Ibid, at [268] per Anderson J.

${ }^{215}$ Ibid, at [111] per Tipping J.

${ }^{216}$ Ibid, at [119] per Tipping J.
} 
legal content at the other end" with the courts exercising a greater intensity of review of those matters more at the legal content end of the spectrum. ${ }^{217}$ There are weaknesses with this approach because: "the allocation of scarce public resources can often intersect with questions which, from a different standpoint, may seem more legal than political." ${ }^{218}$ The court's discussion of judicial deference and restraint to Parliament reveals that its application will depend on the facts of the case

\section{$1 \quad$ Assessing the value and importance of an objective}

The first step of the proportionality analysis is to assess the objective or public purpose of the limit. Joseph's construction of the element of constitutional review characterises this as an assessment of "the value or importance of the public purpose the decision-maker seeks to achieve". The courts, to assess this element, have largely adopted the language employed in Oakes and ask whether the objective is significant and important which requires an assessment of whether the objective addresses a matter that is pressing and substantial. ${ }^{219}$

The separate judgments in Hansen take different approaches to assessing the whether the public purpose served by s 6(6) of the Misuse of Drugs Act is of value or importance. Chief Justice Elias' judgment does not specifically discuss the public purpose, the Chief Justice instead considers s 6(6) of the Misuse of Drugs Act in the broader context of the right concerned and other criminal offending concluding that: "[i]t is not at all clear that there is any principled basis upon which the risk of nonpersuasion and therefore the risk of wrongful conviction is properly transferred to someone accused of drug dealing." 220 In contrast, Anderson J considers the importance of the objective of combating "the widespread and destructive use of and dealing in controlled drugs" as so obvious that "[t]he health, safety and economic implications are of a degree which needs no elaboration."221

In contrast, Blanchard, Tipping, and McGrath JJ in Hansen all conclude that the public purpose is important because it responds to a general concern that is "pressing and substantial". ${ }^{222}$ All three of these judgments refer to either 'Parliament' or the 'legislature' in the course of determining whether the public purpose is important.

\footnotetext{
${ }^{217}$ Ibid, at [116] per Tipping J.

218 Ibid.

${ }^{219}$ Ibid, at [42] per Elias CJ; [64] per Blanchard J; [103] and [120] per Tipping J; [185] per McGrath J.

${ }^{220}$ Ibid, at [44] per Elias CJ.

${ }^{221}$ Ibid, at [273] per Anderson J.

${ }^{222}$ Ibid, at [69] per Blanchard J, at [103], [108], [113] and [125] per Tipping J, at [203], and [207] per McGrath J, and at [272]-[273] per Anderson J.
} 
McGrath $\mathrm{J}$, in concluding that there is an important objective defers completely to Parliament: ${ }^{223}$

Whether that is a pressing concern in New Zealand is a question of social policy on which democratic principle calls for respect for the legislature's assessment. Having regard to the legislature's constitutional responsibility it would be rare in New Zealand for the courts to decide that the objective of the legislature in criminalising certain behaviour was in pursuit of a policy goal that was not a legitimate aim. In any event, I have no hesitation in concluding that both aspects of the legislature's objective, as described, amount to a pressing social concern in New Zealand of sufficient importance that its pursuit may legitimately override protected freedoms.

Blanchard $\mathrm{J}$ takes a different approach by attributing Parliament with a conscious decision to override the Bill of Rights Act to give effect to the policy objectives behind the provision. ${ }^{224}$ While this is a different approach to that of McGrath $\mathrm{J}$ and Anderson $\mathrm{J}$, the effect is the same: there is no independent assessment of the value or importance of the objective.

Deference to Parliament when determining whether the objective is of value or important is problematic because it is easy to get drawn into a de facto assumption that if Parliament has legislated for $\mathrm{X}$, then $\mathrm{X}$ is of value or importance because Parliament would intervene with legislation if that intervention was necessary and important. While this approach would be in keeping with protection of the doctrine of parliamentary sovereignty, an impartial assessment of the objective of a limit can be achieved without encroaching on Parliament's domain. Such an approach is evident from the judgment of Tipping $\mathrm{J}$ because while Tipping $\mathrm{J}$ describes the objective as "Parliament's objective" to locate the objective in the democratic decision-making body he makes an independent assessment of that objective stating: ${ }^{225}$

I am satisfied that Parliament's objective was sufficiently important to justify some limitation of the presumption of innocence. Dealing in illegal drugs is a major social concern and has the capacity to do immeasurable harm to society and its individual citizens. The presumption contained in s 6(6) of the Misuse of Drugs Act 1975 is obviously designed to make the task of establishing guilt

\footnotetext{
${ }^{223}$ Ibid, at [207] per McGrath J.

${ }^{224}$ Ibid, at [69] per Blanchard J.

${ }^{225}$ Ibid, at [125] per Tipping J.
} 
easier for the prosecution. That will indirectly have some deterrent effect. These interrelated objectives relate to a matter which I am satisfied is one of serious and pressing social concern.

In "The Charter Dialogue between the Courts and Legislatures", Hogg and Bushell observe that the Canadian courts have rarely found that a law does not have a "pressing and substantial" purpose before noting two exceptions, as at 1997, in which the courts did find that the objective did not meet the threshold: $R v$ Big M Drug Mart Ltd in which the Supreme Court of Canada struck down the federal Lord Days Act because the purpose to "compel the observance of the Christian Sabbath" was inconsistent with the guarantee of freedom of religion; and Sommerville $v$ Canada (AG) (1996) in which the Alberta Court of Appeal dismissed the objectives behind the limits on third party election spending and advertising blackouts. ${ }^{226}$

While deference and restraint is a vital tool for ensuring comity between the courts and Parliament, caution should be exercised because unquestioning deference to Parliament about whether an objective is important may, depending on the case, inhibit the courts ability to make a fair and impartial assessment about whether the limit is a proportionate response to the problem.

\section{Judicial analysis of the policy options}

As part of the proportionality assessment, the courts assess whether the desired purposes (the ends) could be achieved in less intrusive ways (the means). ${ }^{227}$ An argument often made is that judges lack institutional capacity to perform the proportionality test because, unlike elected representatives, they do not have access to the policy reasons and views of the public on which the decisions are based and that this makes such an assessment by the courts unconstitutional. ${ }^{228}$ This concern is especially relevant when courts assess whether the limit impairs the right as little as is reasonably necessary because the courts generally compare the means chosen with alternative options.

The comparison of alternative options involves policy analysis through identifying different ways in which Parliament could have approached the problem to achieve the objective. The approach the courts take to assessing this element of the proportionality test is derived from Oakes and was originally a requirement that there

\footnotetext{
${ }^{226}$ Hogg and Bushell "The Charter Dialogue", above n 111, at 93-94.

227 Joseph "Constitutional Review Now", above n 3, at 90-91.

${ }^{228}$ See Mark Henaghan, "Same-sex Marriages in the Court of Appeal", above n 55.
} 
be "as little interference as possible with the right". However, as noted in Rishworth, Dickson CJ later modified this element in $R v$ Edward Books and $\mathrm{Art}^{229}$ to require that rights be limited "as little as is reasonably possible." 230 A similar restatement of this element can be found in the Supreme Court of Canada's judgment in Chaulk. ${ }^{231}$

The description of how to approach of this element in Hansen varies across the judgments and is somewhat confusing. Anderson J appears to take the more restrictive approach from Oakes but refers to Chaulk when he recasts the element to read: ${ }^{232}$

A limitation of an affirmed right or freedom will not be demonstrably justified in a free and democratic society unless it: ... (c) in light of its intended purpose, is the least possible impairment; and ...

Similarly, McGrath $\mathrm{J}$ in Hansen accepts this aspect as a both "crucial and difficult" part of the proportionality analysis and cites the guidelines set by the Court of Appeal in Moonen (No1) as authority. ${ }^{233}$ While Moonen (No.1) refers to Oakes for this aspect it does not discuss the restatement 'as little as is reasonably necessary' of the element by the Canadian Supreme Court in Chaulk or Edwards. ${ }^{234}$ When discussing the application of this element, McGrath $\mathrm{J}$ frames the question as: "whether the measure intrudes on the presumption of innocence as little as possible, in other words whether there is minimal impairment"; he then goes on to state that the alternative has to have a "similar level of effectiveness". 235

Blanchard $\mathrm{J}$ starts by noting that assessing the means chosen to achieve the objective must impair the right or freedom as "little as possible" is an analytical element for determination and relies on Oakes for this proposition. ${ }^{236}$ However, when applying the element Blanchard J states that the decision in Chaulk acknowledges that "a choice could be made from a range of means which impaired the right as little as was reasonably necessary." 237

Tipping $\mathrm{J}$ summarises the question as "does the limiting measure impair the right or freedom no more than is reasonably necessary for sufficient achievement of its

\footnotetext{
${ }^{229} R v$ Edward Books and Art [1986] 2 SCR 713 at 772.

${ }^{230}$ Rishworth, The New Zealand Bill of Rights, above n 91, at 179-180 and 185.

${ }^{231} R$ v Chaulk, above $\mathrm{n} 125$ at 1335-1336.

${ }^{232}$ Hansen, above n 8, at [272] per Anderson J.

${ }^{233}$ Moonen (No.1), above n 56.

${ }^{234}$ Hansen, above n 8, at [217] per McGrath J.

${ }^{235}$ Ibid, at [217] per McGrath J.

${ }^{236}$ Ibid, at [79] per Blanchard J.

${ }^{237}$ Ibid, at [79] per Blanchard J.
} 
purpose?"238 and sets out the following description of how this element can be satisfied: ${ }^{239}$

The court must be satisfied that the limit imposed on the presumption of innocence is no greater than is reasonably necessary to achieve Parliament's objective. I prefer that formulation to one which says that the limit must impair the right as little as possible. The former approach builds in appropriate latitude to Parliament; the latter would unreasonably circumscribe Parliament's discretion. In practical terms this inquiry involves the court in considering whether Parliament might have sufficiently achieved its objective by another method involving less cost to the presumption of innocence.

Two accounts of the Supreme Court's approach to this element in Hansen as part of the test under s 5 of the Bill of Rights Act offer differing views about the application of this element. Wilberg's article in "The Bill of Rights and other enactments" considers that there is a two-to-two divide between restating the original Oakes test and the qualified 'reasonably necessary' recasting of this element misses an opportunity to clarify the approach post Moonen (No.1). In contrast, Petra Butler's discussion of Hansen observes: ${ }^{240}$

Rather those judges explicitly or implicitly accepted that in line with later Canadian authority Parliament was "not required to search for and to adopt the absolutely least intrusive means of obtaining its objective".

How this test is configured is material to whether the courts may be intruding on the domain of Parliament; in contrast to the threshold being "as little as possible", the "as little as reasonably possible" or "as little as reasonably necessary" configurations give the courts room to apply deference. The "as little as reasonably necessary" configuration recognises that there may be more than one reasonable policy response to a problem that falls within an acceptable range of policy options given their limited effect on the right. While the courts statements about how to approach the element bear out the two-to-two divide, consideration of how the analysis was performed, not just what was said, bears out the conclusion that the "little as reasonably necessary" test is that which is applied by the courts. For example, McGrath $\mathrm{J}$ and

\footnotetext{
${ }^{238}$ Ibid, at [104] per Tipping J; see also [121].

${ }^{239}$ Ibid, at [126] per Tipping J.

${ }^{240}$ P Butler "Student Companion $R v$ Hansen", above n 189, at 48.
} 
Anderson $\mathrm{J}$ build in the reasonableness by requiring the alternative to have a similar level of effectiveness (McGrath J) or to be viewed in light of the purpose (Anderson J).

In applying this element in Hansen Elias CJ, Tipping, McGrath, and Anderson $\mathrm{JJ}$ identify alternative approaches that would be a less intrusive means of achieving the objective; in contrast Blanchard $\mathrm{J}$ considers that the reverse onus resulting from the presumption in s 6(6) of the Misuse of Drugs Act is the only effective approach for achieving the objective. The discussion below of how the courts applied this test demonstrates that it can be done in a way that preserves the legislative supremacy of Parliament while ensuring the integrity of the analysis and objective of the Bill of Rights Act to promote and protect human rights.

In the course of describing different types of evidential and legal burdens in criminal proceedings Elias CJ explores whether an evidential burden would have been a less intrusive means of achieving the objective. Specifically, Elias CJ considers whether a presumption of fact is a viable alternative; a presumption of fact: "creates an evidential burden on the party against whose interests the presumption operates by requiring him to point to evidence upon which the trier of fact could find against the presumption." ${ }^{241}$ After determining that s 6(6) of the Misuse of Drugs Act cannot be construed that way under s 6 of the Bill of Rights Act, the Chief Justice concludes: ${ }^{242}$

It is difficult to see that evidential difficulties for the prosecution in the present case could not have been sufficiently addressed by a presumption of fact which leaves the onus of proof on the prosecution.

Tipping J considers that, in this case, an evidential burden is the "only serious candidate" as an alternative, noting that: ${ }^{243}$

The evidential burden gives rise to less risk that a person who had no purpose of supply would be convicted because he was unable to rebut the presumption. The persuasive burden has a greater capacity to catch those who are not actually guilty of possession for supply.

Tipping $\mathrm{J}$ considers that this alternative would put the Crown in a "materially better position than if there was no presumption at all", by giving the Crown a forensic

\footnotetext{
${ }^{241}$ Hansen, above $\mathrm{n} 8$, at [33] per Elias CJ.

${ }^{242}$ Ibid, at [39] - [44] per Elias CJ.

${ }^{243}$ Ibid, at [127] per Tipping J.
} 
advantage that would have a deterrence effect also. ${ }^{244}$ With this in mind, Tipping $\mathrm{J}$ concludes that s 6(6) of the Misuse of Drugs Act "impairs the right to be presumed innocent to a greater extent than is reasonably necessary to achieve Parliament's objective". 245

McGrath J considers that there is an "obvious alternative" for approaching the objective "of drying up supplies of illicit drugs and facilitating detection and prosecution of drug dealing, namely by imposing only an evidential onus on the accused."246 McGrath J notes the challenging position Parliament is in making such decisions especially in light of the evidence from Police before select committee that proof of dealing intention is problematic, but then goes on to caution that: ${ }^{247}$

The problem of proof of purpose in this context should not, however, be overemphasised. Even in the absence of any statutory presumption an intent to supply drugs may be inferred from evidence of the quantity of drugs found in a person's possession.

McGrath J elaborates on this point with an example and then, like Tipping J, considers that the evidential onus would have some effects that are advantageous to the prosecution. $^{248}$ McGrath $\mathrm{J}$ also examines the approach in England and the Australian State of Victoria to support the conclusion that an evidential onus is consistent with the presumption of innocence and will not unnecessarily hamper the prosecution of drug dealing offences finally concluding that an evidential burden is a less intrusive means of achieving the objective. ${ }^{249}$

Anderson $\mathrm{J}$ takes a different approach from his colleagues. After concluding that there is not a rational connection between the Expert Committee's advice about the trigger levels for setting the thresholds and the purpose of the limit on the right to be presumed innocent, Anderson J explores whether the Expert Committee's opinion itself could be used as evidence in prosecutions for drug dealing: ${ }^{250}$

The trigger level is fixed in light of the opinion of the Expert Committee, indicating that the opinion is factual information from which, as a

\footnotetext{
${ }^{244}$ Ibid, at [128] - [129] per Tipping J.

${ }^{245} \mathrm{Ibid}$, at [129] per Tipping J.

${ }^{246}$ Ibid, at [217] per McGrath J.

${ }^{247}$ Ibid, at [219] per McGrath J.

${ }^{248}$ Ibid, at [220] per McGrath J.

${ }^{249}$ Ibid, at [220] - [224] per McGrath J.

${ }^{250}$ Ibid, at [277] - [279] per Anderson J.
} 
generalisation, a purpose may be inferred. If that is so, the quality of the opinion is essentially evidential, not probative. Its evidential value will vary according to the whole of the factual context. To the extent that an opinion has evidential relevance it could properly be put before a court, but the presumption goes further than that.

Anderson J does acknowledge the "significant issues of cost, convenience, and practicability in putting before a court the opinion of an expert body" but considers that there are ways to ameliorate these issues and goes on to draw a comparison with an experienced member of the Police providing evidence about the conduct of drug dealers. $^{251}$ Anderson J concludes, in light of this alternative, that s 6(6) of the Misuse of Drugs Act is too intrusive. ${ }^{252}$

In considering whether there are less intrusive means of achieving the objective, Blanchard J's analysis diverges from that of his colleagues because he concludes that there is no effective alternative. Blanchard $\mathrm{J}$ starts by reiterating the prosecutorial difficulty in proving the intention of possession for street dealing. ${ }^{253}$ Blanchard $\mathrm{J}$ considers that the alternative of an evidential burden would, in practical terms, have the same effect a legal burden on the Crown to prove beyond reasonable doubt that the accused had the requisite purpose. Blanchard $\mathrm{J}$ goes on to conclude that: the presumption in s 6(6) of the Misuse of Drugs Act is the only effective means of remedying the prosecutorial difficulty and, therefore, to achieve the public purpose. ${ }^{254}$ In the lead up to Blanchard J's discussion of this element, the judgment is bereft of analysis about the nature of the right to be presumed innocent; this may be why the discussion of alternatives appears lopsided and to focus more on the policy objective.

For four of the judges in Hansen the presence of an effective alternative for achieving the objective means that s 6(6) of the Misuse of Drugs Act could not be considered to limit the right as little as was reasonably necessary. As for judicial analysis of the importance of the objective; the analysis of the means of achieving the objective strays into the domain of Parliament because it not only challenges the choice made by Parliament but also looks at different policy options that could have been adopted.

However, there are two factors that save the courts and continue to show respect for the role of Parliament. First, the courts are looking at whether the means falls within

\footnotetext{
${ }^{251}$ Ibid, at [279] per Anderson J.

${ }^{252}$ Ibid.

${ }^{253}$ Ibid, at [79] per Blanchard J.

${ }^{254} \mathrm{Ibid}$, at [79] per Blanchard J.
} 
a range of reasonable alternatives, not whether the means is the least intrusive way of achieving the objective. Secondly, as Wilberg observes, the fact that Tipping and McGrath JJ continue their analysis even after concluding that the minimal impairment threshold had not been reached suggesting that this test "is not a hurdle which must be passed but rather a factor that feeds into the final proportionality test". 255

Balancing of the public interests

The final aspect of the proportionality test is to determine where the balance lies by weighing up the public interest in the right with the public interest in the limit. This assessment necessarily draws together all the threads of the other elements of the analysis: the nature of the right, the effect of the limit, the objective of the limit, and whether the limit only limits the right "as little as is reasonably necessary".

Rishworth observes that the courts have largely adopted the approach of the Canadian Supreme Court using Oakes as the touchstone for assessing where the balance lies. In the course of discussing Oakes, Rishworth notes the position taken by Hogg that this branch of the Oakes test is redundant because: "[a] judgment that the effect of the law were too severe would surely mean that the objective was not sufficiently important to justify limiting a Charter right."256 Rishworth's counters Hogg's position by referring to the decision Thomson Newspapers Co $v$ Canada (Attorney-General) that states that: ${ }^{257}$

The third stage of the proportionality analysis provides an opportunity to assess, in light of the practical and contextual details which are elucidated in the first and second stages, whether the benefits which accrue from the limitation are proportional to its deleterious effects measured by the values underlying the Charter

This approach is consistent with the observation made by Wilberg that the preceding elements of the proportionality analysis are factors rather than hurdles. Nevertheless, this final assessment is the most controversial part of constitutional review from the orthodox perspective because the courts are, in effect, revisiting the decision already made by Parliament about where the public interest lies: with the right or with the limit. The matters considered as part of the balancing analysis will vary

\footnotetext{
${ }^{255}$ Wilberg "The Bill of Rights and other enactments", above n 190, at 114.

${ }^{256}$ Rishworth The New Zealand Bill of Rights, above n 91, at 181 quoting Peter Hogg (ed) Constitutional Law of Canada (Looseleaf ed, vol 2, 1997) at [35.12 n 20].

${ }^{257}$ Thomson Newspapers Co v Canada (Attorney-General) [1998] 1 SCR 877 at 968-970.
} 
according to the facts of the case; there are, however, some regular attendees: the effect of the limit, the reasonableness of over options, and the public interest associated with both the right and the limit. The complexity of the balancing analysis is evident from the varying approaches taken in each judgment in Hansen.

(a) Consideration of the effect of the limit in the balancing analysis

If the effect of the limit on the right is minimal and the limit comes within the range of reasonable options, then the courts are likely to find that the limit is justified under s 5 of the Bill of Rights Act. If the effect of the limit is not minimal then the courts are likely to increase the intensity of their review under s 5 of the Bill of Rights Act.

In conducting his final assessment under the proportionality analysis, Blanchard $\mathrm{J}$ focuses on the risk of wrongful conviction under s 6(6) of the Misuse of Drugs Act and whether that risk is real or theoretical. ${ }^{258}$ Blanchard $\mathrm{J}$ expresses doubt about whether there would be a negative effect on the right to be presumed innocent for cases under s 6(6) of the Misuse of Drugs Act, but he does not discuss the broader public interest in the right to be presumed innocent in his consideration of this element: ${ }^{259}$

In a very small number of borderline cases - of which the present case is certainly not one - it is possible that a user of illegal drugs could be convicted of possession for supply where there existed a reasonable doubt about purpose. But the consequence of the limitation of the presumption of innocence for such persons (if in fact there are any) would not be disproportionate to the overall net gain to society from the effective operation of the reverse onus. The disincentive to dealers provided by the existence of the reverse onus in s 6(6) and the practical ineffectiveness for the prosecution of anything less than such an onus must, in my view, be given the greater weight.

After noting that s 5 of the Bill of Rights Act requires courts to consider the legitimacy of statutory provisions in their societal context and that includes the fact that s 6(6) of the Misuse of Drugs Act also applies to other drugs controlled by that Act, Blanchard $\mathrm{J}$ concludes that the limit imposed by $\mathrm{s}$ 6(6) of that Act is not

\footnotetext{
${ }^{258}$ Hansen, above $\mathrm{n} 8$, at [80] per Blanchard J.

${ }^{259} \mathrm{Ibid}$, at [81] per Blanchard J.
} 
disproportionate. ${ }^{260}$ Blanchard $\mathrm{J}$ is the only judge in Hansen to conclude that s 6(6) of the Misuse of Drugs Act is a justified limit under s 5 of the Bill of Rights Act. ${ }^{261}$ Blanchard J's judgment reflects judicial restraint in relation to Parliament's decision to enact the limit in s 6(6) of the Misuse of Drugs Act.

In contrast to the judgment of Blanchard J, when Tipping J revisits the issue of the risks associated with setting trigger levels, including the risk of wrongly convicting people, he reaches a different conclusion: ${ }^{262}$

It is the uncertain extent of the potential disparity between the level of probability which arises from where the presumptive level is set and the fundamental general need for the Crown to prove every element of the offending beyond reasonable doubt which lies at the heart of my conclusion that $\mathrm{s} 6(6)$ represents a disproportionate response to what is undoubtedly a matter of genuine social concern. There is no sufficient basis upon which I can conclude that Parliament was entitled to view the matter otherwise.

The different conclusions of analysis of the effect of the limit of the right in the context of the proportionality test may also reflect that Tipping $\mathrm{J}$ presumes that Parliament does not intend to limit rights; whereas, Blanchard $\mathrm{J}$ presumes that if Parliament has enacted a limit it is intended as a justified limit.

(b) Consideration of less intrusive options in the balancing analysis

The availability of options that would be less intrusive on the right is material in the assessments by Elias CJ, Tipping, McGrath, and Anderson JJ. For example, Tipping $\mathrm{J}$ concludes that while the less intrusive alternative of an evidential onus would not be as advantageous as the presumption in s 6(6) of the Misuse of Drugs Act: ${ }^{263}$

...in contrast to the lesser presumption, the Crown's advantage under s 6(6) represents a disproportionate response to the problem being addressed. Under the lesser presumption the risk of wrongful convictions would be significantly reduced and the effectiveness of the presumption from the Crown's point of view would not be inappropriately lessened.

\footnotetext{
${ }^{260}$ Ibid, at [82] per Blanchard J.

${ }^{261}$ Ibid, at [83] per Blanchard J.

${ }^{262}$ Ibid, at [138] per Tipping J.

${ }^{263} \mathrm{Ibid}$, at [136] per Tipping J.
} 
While the judgment of Tipping $\mathbf{J}$ is explicit about this consideration, it can only be inferred from analysis in the other judgments.

(c) Consideration of the public interest in the right in the balancing analysis

Often the focus of the balancing analysis is on the limit and its objective, but examining the public interest in the right is an essential part of the balancing analysis and it is informed by the earlier analysis of the subjective (immediate) and objective (long term) aspects of the right. Both of the right and the limit were enacted by Parliament, and the courts are being asked to determine where the public interest lies; this is a complex and inherently democratic decision - one that is usually reserved for Parliament but sees the courts acting as a check to ensure that the reasons for Parliament's determination are transparent.

Tipping J, like Blanchard J, spends little time in his judgment discussing the nature of the right. However, the discussion of the public interest supporting the right is material in Tipping $\mathrm{J}$ reaching the conclusion that the Crown has not demonstrated that the right to be presumed innocent is outweighed by the objective of s 6(6) of the Misuse of Drugs Act because they failed to show that the provision has "created demonstrably greater social benefits than the damage inflicted on the presumption of innocence." 264 Anderson J takes a different approach that combines the subjective and objective effects of the limit on the right. After concluding that there is no rational connection between the objective and s 6(6) of the Misuse of Drugs Act, and discussing the means for advancing the objective, Anderson $\mathrm{J}$ concludes it is not a proportionate response because dealers can change behaviour to evade and that the reverse onus most affects those for whom the evidence is marginal one way or the other before concluding that: ${ }^{265}$

Because of prosecutorial difficulty in proving a positive, an accused who does not have equality of arms in terms of resources, and may lack articulateness, is forced to carry the even heavier burden of proving a negative. That such negative is subjective and intangible only exacerbates the difficulty for an accused.

\footnotetext{
${ }^{264}$ Ibid, at [137] per Tipping J.

${ }^{265}$ Ibid, at [280] per Anderson J.
} 
Elias CJ states that, in her view, consideration of s 5 does not arise in this case but that she will provide some thoughts on the sorts of considerations should they arise. $^{266}$ In this context, the Chief Justice observes that in weighing up whether a limit is justified: "the ends which might justify a limitation of the human right to be presumed innocent must relate to the particular difficulties of proof or detection which are the immediate reason for the limitation of the right." ${ }^{267}$ After considering such matters, the Chief Justice concludes that: "[s]imply making it easier to secure convictions is not a principled basis for imposing a reverse onus of proof". ${ }^{268}$

McGrath J's discussion of where the balance lies starts by noting the importance of the right to be presumed innocent and that the effect of the reverse onus on that right is substantial. ${ }^{269}$ McGrath $\mathrm{J}$ then goes on discuss how the burden faced by the accused, despite them having material knowledge of intention, would be detrimental to the accused in this case because:

- proving a state of mind is a more difficult exercise than proving a simple fact

- the defence of holding drugs for personal use requires the accused to acknowledge the possession and "that acknowledgement of itself is likely to demean the accused in the eyes of the jury"

- witnesses to support the accused persons version are highly unlikely to be prepared to give evidence in court to that effect. ${ }^{270}$

McGrath $\mathrm{J}$ goes on to observe that in situations where there is a large quantity of drugs it would combine with the effects of the above and the accused "may make it very difficult, if not impossible, to discharge the burden placed on him despite his primary knowledge of what he intended." ${ }^{271}$ McGrath J finally concludes, drawing on the effect of the limit and the right, that s 6(6) of the Misuse of Drugs Act is a disproportionate means of achieving the public purpose of curbing the illicit supply of controlled drugs stating: ${ }^{272}$

\footnotetext{
${ }^{266}$ Ibid, at [8] per Elias CJ.

${ }^{267}$ Ibid, at [43] per Elias CJ.

${ }^{268}$ Ibid, at [44] per Elias CJ.

${ }^{269}$ Ibid, at [226] per McGrath J.

${ }^{270}$ Ibid, at [228] per McGrath J.

${ }^{271}$ Ibid, at [228] per McGrath J.

${ }^{272}$ Ibid, at [233]-[234] per McGrath J.
} 
Overall, in the context of a provision which seriously intrudes on a core value of the criminal justice system, it seems to me that the disadvantages on an accused are disproportionate to those on the prosecution, which will only commence its case if it is able to prove that the accused was caught in possession of a particular quantity of drugs from which fact alone inferences of a purpose of supply of varying strength will be available.

Both Elias CJ and Anderson $\mathrm{J}$ frame their consideration of whether the limit poses a justified limit on the right in the broader context of criminal offending. Elias CJ takes a theoretical route when examining the objective in the broader context of criminal offending comparing this situation to the paradox in criminal procedure by quoting from the judgment of the Constitutional Court of South Africa in $S v$ Coetzee in which Sachs J states: $:^{273}$

The starting point of any balancing enquiry where constitutional rights are concerned must be that the public interest in ensuring that innocent people are not convicted and subjected to ignominy and heavy sentences, massively outweighs the public interest in ensuring that a particular criminal is brought to book.

The Chief Justice reproduces the fulsome explanation by Sachs $\mathrm{J}$ which includes the observation that the "prevalence and seriousness" of the crime are not necessarily material justifications because it is easy to apply such justifications to a range of offending. Anderson $\mathrm{J}$ adopts a similar position to challenge the objective of the limit in the context of other crimes of social concern: ${ }^{274}$

Limiting such use and its effects, including by criminal process, is an important social objective. However, it is not only criminal dealing in drugs which is of great social concern. Sexual abuse and other forms of serious violence, even when not drug related, are also matters of grave concern, yet our society does not and should not contemplate reversing the onus of proof in those types of case. In my view, the misuse of drugs is no more important than those types of criminality.

${ }^{273}$ S v Coetzee, above n 143, at [220] per Sachs J.

${ }^{274}$ Hansen, above n 8, at [273] per Anderson J. 
Elias CJ and Anderson J's discussion of the broader context illustrate how the objective (repressing drug taking) can be weighed not just against the subjective interests right (that is, to s 6(6) of the Misuse of Drugs Act) but also the objective interest in the right generally (ensuring innocent people are not convicted).

With the exception of the judgment of Blanchard J; the Supreme Court, while exercising deference in respect of some elements of the proportionality elements, determined that Parliament's imposition of this limit does not fall within the range of options that would limit the right "as little as is reasonably necessary" and, therefore, is a disproportionate response. This conclusion is consistent with the constitutional role of the courts under the Bill of Rights Act (to affirm, promote and protect human rights) to ensure the transparent of governmental decision-making that, in turn, enables parties to seek that the government be accountable for those decisions. While the courts are unable to strike down the limit McGrath $\mathrm{J}$ reminds us that if the courts find that a limit is a disproportionate response then: ${ }^{275}$

It is then for the other branches of government to consider how to respond to the court's finding. While they are under no obligation to change the law and remedy the inconsistency, it is a reasonable constitutional expectation that there will be a reappraisal of the objectives of the particular measure, and of the means by which they were implemented in the legislation, in light of the finding of inconsistency with these fundamental rights and freedoms concerning which there is general consensus in New Zealand society and there are international obligations to affirm.

This is why even when the courts may, from time to time, wander amongst the policy vegetable patch the courts do not undermine parliamentary sovereignty because it is the legislative branch that has the final say. This is because s 5 of the Bill of Rights Act is subject to s 4, which means, ultimately, that the courts cannot override the limit. Furthermore, the court's decision adds to the democratic dialogue about the policy objectives Parliament pursues on behalf of New Zealand.

\section{Prudent use of judicial deference and restraint}

The Supreme Court decision in Hansen establishes that analysis of limits under s 5 of the Bill of Rights Act is an essential part of determining such cases and that judicial deference will be used as a way of preserving comity, where it is called for,

\footnotetext{
${ }^{275}$ Hansen, above n 8, at [254] per McGrath J.
} 
between Parliament and the courts. The application of judicial deference must not, however, undermine the constitutional role performed by the courts to the disadvantage of the people of New Zealand. In order to establish if s 4 of the Bill of Rights Act applies, first you must establish that a limitation is inconsistent with the Bill of Rights Act because it is unjustified under s 5 of the Bill of Rights Act; circumventing the analysis under s 5 because the courts can not strike down legislation undermines the courts' constitutional role to ensure the transparency of the public decision making reflected in passing legislation and protect and promote human rights. Therefore, deference comes with a warning that it is to be used prudently and not to circumvent the analysis of the right, the objective of the limit, the effect of the limit and the alternative options.

Judicial deference is a necessary part of the proportionality analysis and an important tool for maintaining the comity between the courts and Parliament when performing constitutional review. The courts, and Crown counsel, need to be wary of lazy use of judicial deference so that public confidence in the human rights protections afforded by the Bill of Rights Act and the courts impartiality in reviewing the Crown's actions is maintained in New Zealand. The proportionality analysis should always be made where a legislative provision limits a right or freedom protected by the Bill of Rights Act; judicial deference to Parliament should not be used to shortcut analysis, for example, of whether the provision gives effect to an important and significant objective. While the decision in Hansen provides some insight into the application of judicial deference questions remain about when and how judicial deference should be applied; this is a matter that has actively occupied the courts, members of Parliament, lawyers, officials, and academics alike.

The principles in the dissenting decision of Laws LJ of the Canadian Supreme Court in International Transport Roth Gmbh $v$ Secretary of State for the Home Department $^{276}$ are often cited in academic writing as an example of the multi-factor approach to applying deference and are summarised by Rivers as the following four principles: ${ }^{277}$

(1) greater deference should be paid to Parliament than to subordinate legislative or executive acts; (2) there is less scope for deference in the case of unqualified, or apparently unqualified rights; (3) greater deference should be

\footnotetext{
${ }^{276}$ International Transport Roth Gmbh v Secretary of State for the Home Department [2003] QB 728 at [82]-[87]. Compare $M v H$ [1999] 2 SCR 3 at [305]-[321] per Bastarache J.

${ }^{277}$ Rivers "Proportionality and Variable Intensity of Review", above n 186, at 204.
} 
paid when a matter lies within the constitutional responsibility of the executive (eg defense of the realm) than within the constitutional responsibility of the courts (eg criminal justice); (4) greater deference should be paid where the question turns on matters of executive expertise (eg macro economic policy).

While Laws LJ differed from colleagues in the outcome, Rivers observes that the reasoning in relation to deference did have the support of the Court. ${ }^{278}$ These factors have been added to, elaborated on, substituted, and singled out across academic and judicial writing. ${ }^{279}$ Each of these principles presents different challenges and no one principle, nor a combination of them, offers a complete response to the question of when the courts should defer to Parliament. For example, as discussed by Rivers and Fredman, there are times when the topic of a case are peculiarly within the realm of both Parliament and the courts as exemplified by United Kingdom decision in $A v$ Home Secretary in which national security (responsibility of the Executive) and right to fair trial (responsibility of the courts) meet. ${ }^{280}$ The Court of Appeal decision in Poumako is another example of how a case can occupy both spaces with equal intensity.

An alternative approach that is currently gaining favour is to use two guiding principles: institutional competence and legitimacy. ${ }^{281}$ Rivers in "Proportionality and Variable Intensity of Review" takes these two guiding principles one-step further and distinguishes the nature of the judicial response according to the different principles. "Judicial deference" would apply when the courts defer to another's decision on the basis of institutional competence, and "judicial restraint" applies when the courts are competent to make a decision but exercise restraint because such a decision may not be legitimate. ${ }^{282}$ These two guiding-principles are looked at in turn below.

\section{Principle of institutional capacity and judicial deference}

Insufficient institutional capacity or competence on the part of the courts is frequently cited as a reason why courts may need to exercise judicial deference to Parliament. A comparison of the challenges courts face with those facing members of Parliament reveals that they appear to be manifestly the same. For example, regardless

\footnotetext{
${ }^{278}$ Rivers "Proportionality and Variable Intensity of Review", above n 186, at 22.

279 See generally Sandra Fredman "From Deference to Democracy: The role of Equality under the Human Rights Act" (2006) 122 Law Quarterly Review 53; and Rivers "Proportionality and Variable Intensity of Review", above n 186.

280 See generally Fredman "From Deference to Democracy", above n 279, at 57; and Rivers "Proportionality and Variable Intensity of Review", above n 186, at 203-205.

${ }^{281}$ Rivers "Proportionality and Variable Intensity of Review", above n 186.

${ }^{282}$ Rivers "Proportionality and Variable Intensity of Review", above n 186, at 191-194.
} 
of the forum, time pressures on parties are common and such time pressures affect the quality of the research including the collection, analysis, and comprehension of information and the reliability of the sources of that information resulting in a variable quality in the information presented to the courts and select committees alike. Likewise the variable expertise and experience of counsel is not limited to those appearing before the courts; it is also evident in government advisers and submitters before select committee - this is no way detracts from the conscientious efforts of those who participate in these forums, but reflects that people come from varied backgrounds with different experiences and training, and divergent views about the way in which something should be done. For example, an expert witness before either forum may have considerable knowledge of an area of law or scientific research but be unaccustomed to presenting to a general audience in a non-technical manner. There are very few parties appearing before the courts or select committee who have an "open cheque-book" and who do not, in some way, have to make the most of what they've got.

The adversarial nature of court proceedings is often cited as an institutional constraint for the courts; however, it is important to realise that the House of Representatives determines the final formulation of legislation through debate and positional bargaining. The adversarial nature of the judicial process arguably gives an added opportunity for the evidence to be tested by an independent decision-maker who does not represent a partial position. As Tipping J's target metaphor in Hansen suggests, the analysis by the courts is not to identify the "right" solution but to designate the range of options from which Parliament may legitimately select an outcome - this is the range of situations in which the judiciary may need to defer to Parliament. $^{283}$

In practice, it appears the institutional constraints faced by the courts are not too different from those of the House of Representatives. Therefore, it is opportune to revisit the lack of institutional capacity argument and look instead at the respective institutional advantages of the courts and Parliament. The obvious institutional advantage for members of Parliament is that they have more direct access to the public including public opinion on policy matters through the select committee process, electorate duties, and political party discussions. Parliamentarians formulate their positions to reflect the values and views of sectors of the community on a policy problem. Their position is likely, however, to reflect a bias based on their political

\footnotetext{
${ }^{283}$ Hansen, above $\mathrm{n} 8$, at [119] per Tipping $\mathrm{J}$.
} 
party's position and the position is likely to be the popular position and, in the case of the larger political parties, the majoritarian position. Clayton in his article on judicial deference and the democratic dialogue theory ${ }^{284}$ recalls Cory J's statement in Vriend $v$ Alberta that "... we must remember that the concept of democracy is broader than the notion of majority rule, fundamental as that may be." 285

The institutional advantage of the courts is that judges are practiced, independent and impartial decision-makers, insulated from popular political concerns. There is little mystery to policy analysis; in general, a policy should represent a proportionate solution to an identifiable problem in pursuit of a particular objective or outcome. The designing of a proportionate solution should be based on evidence. These are all analytical skills that judges apply on a day-to-day basis: judges are professional decision-makers.

While appealing to practical considerations, the principle of institutional competence places too much weight on the differences without acknowledging the similarities between parliamentary and judicial proceedings. Undoubtedly, there may be situations in which institutional competence is material; however, the principle of institutional capacity is weak and leads the analysis away from the material issue before the courts: whether the limit is justified under s 5 of the Bill of Rights Act. The institutional capacity weaknesses of the courts in constitutional review are already mitigated by the use of the purposive approach and their willingness to hear legislative fact evidence.

Constitutional review of legislation presents an opportunity for the New Zealand public to get two bites of the democratic cherry: policy problems can be analysed in both a partial (Parliament) and impartial (the courts) environments and the constitutional cultural preference to retain Parliament as final decision-maker is preserved by s 4 of the Bill of Rights Act. The principle of institutional capacity does not, however, help us determine when judicial deference should apply to review of legislation by the courts instead it offers us an insight into why the courts may need to exercise deference to Parliament.

\footnotetext{
284 Richard Clayton "Judicial deference and "democratic dialogue": the legitimacy of judicial intervention under the Human Rights Act 1998" (2004) Public Law 33 ["Judicial deference"].

${ }^{285}$ Vriend v Aberta [1998] 1 SCR 493 at [140] per Cory J.
} 
The absence of a codified constitution means that the stable governance of New Zealand relies on comity between the courts and Parliament. ${ }^{286}$ This means that legitimacy to make a particular judicial decision, under the New Zealand constitution, is determined by both legal and political factors. The "principle of legitimacy" in this context reflects the fact that while the courts may be competent to make a decision; direct access to the general public and accountability mechanisms in place may mean that Parliament is better placed to make the call in a particular case and the courts should exercise judicial restraint.

The courts serve an invaluable role in a democracy as an impartial decision maker; the stability of a nation and its economic growth is often judged not only by its electoral, governance and regulatory systems but also the ability of the courts to administer justice effectively and impartially. Justice Tipping's observation in Hansen about the role of the courts to safeguard the rights of minorities is salient as it reminds us that constitutional review gives us benefit of both the representative policy making by Parliament and the impartiality of the courts to review that law for consistency with the Bill of Rights Act. ${ }^{287}$ The volume of annual legislative amendments attests to the fact that the "perfect law" is a mythical creature and that law is the product of an iterative process that must adapt and change with the values and needs of the country. Ultimately, the final call about where the line should be drawn rests with Parliament by virtue of s 4 of the Bill of Rights Act.

Section 4 of the Bill of Rights Act clearly retains the ultimate position that Parliament alone has the final say on what the law should be; this is said to be a reflection of New Zealand's preference for the representative and accountable decisionmaking process rather than judicial process in matters of policy. ${ }^{288}$ However, because of s 4 of the Bill of Rights Act even if the judiciary finds that a limit is unjustified, the court cannot alter it and such a decisions will not result in the law being inoperable; therefore, there is no legal risk associated with a negative finding by the courts. There may, however, be constitutional risks for the courts such as: loosing public confidence if the judicial decision and putting the executive and legislative branches in a tight spot highlighting the weaknesses in the policy which may strain the relationship between the courts and the other branches of government.

\footnotetext{
${ }^{286}$ See Butler and Butler The New Zealand Bill of Rights Act: A Commentary, above n 43, at ch 5.

${ }^{287}$ Hansen, above $\mathrm{n} 8$, at [107] per Tipping J.

${ }^{288}$ See Justice and Law Reform Committee Final Report, above n 86, at 3; and Palmer "New Zealand Constitutional Culture", above n 25, at 575-578.
} 
Therefore, it would be sensible for the courts to consider whether they may need to exercise judicial restraint when performing constitutional review for matters in which: the law or policy is a novel response to the problem that has not had much success with conventional solutions; the legislative response, while not offering the least infringement on the right, falls within the range of reasonable alternative policy options; or the law reflects the response to a polycentric policy matter (one for which there are competing views). ${ }^{289}$ These three situations are ones in which, in final step of weighing up the competing public interests under the proportionality test, the courts will have to consider whether to exercise judicial restraint; these situations should not act to circumvent the consideration of the limit through the proportionality test.

The proportionality test should not be circumvented in cases in which the courts may need to exercise restraint because not only are the courts impartial decision-makers but they are also in a more powerful position than the public to compel Parliament to explain their actions: $:^{290}$

At the very least, the appropriate judicial role in such a situation should be to require decision-makers to explain their decisions publicly. This does not undermine democracy, but enhances it, strengthening accountability by exposing decisions to public scrutiny.

The principle of legitimacy is a practical and useful guiding principle because it recognises that where constitutional values, such as human rights, are the subject of legal proceedings the outcome is not purely legal and restricted to the applicant but also have a political and social dimension. Caution must, however, be exercised to ensure that too much weight is not put on Parliament's democratic role at the expense of the courts democratic role as a forum for increasing public scrutiny of decisions. The principle of legitimacy does not offer a complete answer to when the courts may need to exercise deference or restraint.

\section{Proportionality test, intensity of review, and deference}

The guiding principles of institutional competence and legitimacy offer some assistance to understanding when the courts should apply deference or restraint but shift the focus away from the heart of issue: whether the limit is a justified limitation on

\footnotetext{
${ }^{289}$ Rivers "Proportionality and Variable Intensity of Review", above n 186, at 189-190. I am grateful to Chris Curran and Rob Kirkness for their insights into the special circumstances, such as the novelty of the policy response, in which judicial deference may be an appropriate.

${ }^{290}$ Fredman "From Deference to Democracy", above n 279, at 62.
} 
the right. Despite the desirability of a clean and simple set of guiding principles for determining when judicial deference may be appropriate; this desire is naïve because, as can be observed from the decision in Hansen, the need for deference or restraint depends on the facts of the case and the seriousness of the effect of the limit on the right. Rivers identifies the seriousness of the limitation on the right in question as a single characteristic for determining the intensity of review: ${ }^{291}$

The doctrine of proportionality requires that the more seriously a right is limited, the greater must be the gain to the public interest to justify it. Variable intensity of review states that the more seriously a right is limited, the more argument and evidence the court needs to be convinced that the justification is indeed as strong as it is alleged to be.

This characteristic is also helpful for determining the degree to which the courts should exercise deference or restraint in a given case because it goes to the facts of the case and whether the limit is justified. For example, the case for deference or restraint is less persuasive if the effect on the right is serious and the limit only represents a marginal gain for the public.

In terms of when the principles of institutional competence and legitimacy should apply, Rivers considers that neither principle should be available for assessing the objective or purpose but that it may be appropriate for the other stages of the analysis. $^{292}$ Given the essential role the courts play in ensuring transparency of democratic decision-making through performing constitutional review, a prudent path that would reserve consideration of whether deference or restraint is required until the final balancing of public interests is preferable. The analysis of the elements of the important and significant objective and the reasonable policy alternatives can be established on a largely factual basis by examining the reasons behind the law, and identifying whether there are reasonable policy alternatives that may reduce the negative effect of a law on the right.

The proportionality test, as observed by Rivers: "is not simply a legal device to assist judges in regulating legislative and executive incursions on rights. It is better understood as a rational device for the optimisation of interests." 293 Therefore, the final balancing of the public interests, which engages a more complex assessment of

\footnotetext{
${ }^{291}$ Rivers "Proportionality and Variable Intensity of Review", above n 186, at 207.

${ }^{292}$ Rivers "Proportionality and Variable Intensity of Review", above n 186, at 195-201.

${ }^{293}$ Rivers "Proportionality and Variable Intensity of Review", above n 186, at 207.
} 
values that are not purely legal values, is the most appropriate stage of the proportionality test to exercise deference or restraint - if the facts call for it. Restricting this analysis to the final stage of the proportionality test acknowledges the role the courts play in New Zealand's democracy and the necessary cooperative relationship between Parliament and the courts: ${ }^{294}$

As a start the democratic process does not perform its function properly if decision-makers are under no duty to justify their decisions openly. Equally importantly, the ability to remove leaders at an election is not a sufficient safeguard in cases in which the claim is that the rights of individuals must give was to the interests of the community.

The pragmatic desire to utilise the respective institutional advantages of both Parliament and the courts as part of the democratic process in New Zealand requires a concession that judicial deference or restraint in the weighing up of the public interests may, depending on the facts, be necessary as part of the final step of the proportionality assessment.

\section{E Constitutional review and declarations of inconsistency}

The notable weakness of constitutional review of legislation under the Bill of Rights Act is the uncertainty about the remedies available if a legislative provision is found to be an unjustifiable limitation on a right in the Bill of Rights Act. In other jurisdictions the courts can either strike down the limit (such as in Canada) or issue a declaration of inconsistency (such as in England). In New Zealand, s 4 of the Bill of Rights Act expressly prohibits the striking down of legislation and the absence of a remedies clause in the Bill of Rights Act means that the remedies available in constitutional review are still unclear. Nevertheless, declarations of inconsistency appear to be the most likely candidate for a remedy under constitutional review.

A declaration of inconsistency is a declaration that legislation is inconsistent with a right or freedom contained in the Bill of Rights Act and the limit is not justifiable in terms of s 5 of the Bill of Rights Act, (may also be called a "declaration of incompatibility"). Declarations of inconsistency as a remedy have been on the mind of many a judge, lawyer, academic, public servant and, no doubt, politician. The arguments for and against the courts issuing declarations of inconsistency have been

\footnotetext{
${ }^{294}$ Fredman "From Deference to Democracy", above n 279, at 62.
} 
described of as finely balanced and centre about the concepts of authority, procedural implications, use of judicial resources, and the preservation of comity between the courts and Parliament. These arguments have been rehearsed on many occasions and while this chapter notes these arguments it does not seek to revisit those discussions; instead, this chapter examines whether a declaration of inconsistency may undermine the constitution by looking at the legal authority for declarations and the legitimacy of issuing such a declaration.

A common challenge to whether declarations of inconsistency are a legitimate remedy is that the courts lack legal authority to issue such declarations. For example, there is no provision in the Bill of Rights Act setting out that the courts have the power to issue declarations of inconsistency and, as some commentators and lawyers, have argued specific legislative authorisation would be necessary because of the procedural implications. ${ }^{295}$ In addition, because the Human Rights Act 1993 specifically provides for declarations of inconsistency to be issued under s 92J(2) of that Act but the Bill of Rights Act does not; some commentators and lawyers argue that this demonstrates that Parliament does not intend for the courts to have this power in relation to the rights and freedoms in the Bill of Rights Act.

These arguments fail to acknowledge that the alternative that because the Bill of Rights Act is silent on the remedies that may be issued by the courts for breaches; the Act does not limit the ability of the courts to modify existing remedies or create new remedies using the common law. While the remedies clause proposed in the White Paper was removed at the same time as the supreme law provision; this does not have the effect of overriding the common law principle that "where there is a right there is a remedy". This common law principle is an enduring one that Parliament would have needed to expressly override, and could have done so in similar terms to the preservation of legislative supremacy represented by section 4 of the Bill of Rights Act. ${ }^{296}$ In Baigent's case compensation for breach of the Bill of Rights Act was awarded thereby creating as a new public law remedy under the Bill of Rights Act. ${ }^{297}$ The Court of Appeal saw this development as essential: ${ }^{298}$

\footnotetext{
${ }^{295}$ Poumako, above n 57, at [91] per Thomas J; Butler and Butler The New Zealand Bill of Rights Act: A Commentary, above n 43, at 28.5.9, 28.5.12 and 28.5.14; Boscawen v Attorney-General [2008] NZAR 468 (HC), above n 75, at [56].

${ }^{296}$ See discussion in Law Commission Crown Liability and Judicial Immunity, above n 102, at 18-19.

${ }^{297}$ Baigent's case, above n 41 .

${ }^{298}$ Ibid, at 676 per Cooke P.
} 
The Act is binding on us, and we would fail our duty if we did not give an effective remedy to a person whose legislatively affirmed rights have been infringed. In a case such as the present the only effective remedy is compensation. A mere declaration would be toothless."

While a declaration may have been considered toothless in that context because the involved the illegal actions of State officials, declarations do have their merits in the context of constitutional review. The New Zealand Government decided, after considering the recommendations of the Law Commission, not to revoke the public law compensation remedy or to amend the Bill of Rights Act by expressly removing the ability for the courts to develop remedies for breaches of the Bill of Rights Act. ${ }^{299}$

Declarations of inconsistency as a remedy have been discussed in some judgments; with the judgment in Moonen (No.1) generating optimism that such a remedy will be awarded. In Moonen (No.1) Tipping J, for the court, observes: ${ }^{300}$

[Section 5] was, however, retained and should be regarded as serving some useful purpose, both in the present statutory context and in its other potential applications. That purpose necessarily involves the Court having the power, and on occasions the duty, to indicate that although a statutory provision must be enforced according to its proper meaning, it is inconsistent with the Bill of Rights, in that it constitutes an unreasonable limitation on the relevant right or freedom which cannot be demonstrably justified in a free and democratic society. [Emphasis added]

This statement generated much excitement and enthusiasm that a "judicial indication" would be in the form of a declaration of inconsistency along those lines suggested by Brookfield in 1992. ${ }^{301}$ For example, Andrew Butler in an article published in 2000, weighs up the arguments for and against declarations of inconsistency concluding that they are finely balanced, in his view, in favour of such declarations and also observes: ${ }^{302}$

Judicial indications of inconsistency will have a significant impact upon the current paradigm of the constitutional role and function of the judiciary putting significant practical power into the hands of the judges, even if nominally the

\footnotetext{
${ }^{299}$ Law Commission Crown Liability and Judicial Immunity, above n 102.

${ }^{300}$ Moonen (No.1), above n 56, at [20] per Tipping J.

${ }^{301}$ Brookfield "Constitutional Law", above n 32, at 237-237.

${ }^{302}$ A Butler "Judicial Indications of Inconsistency", above n 32, at 59-60.
} 
locus of legal power remains firmly with Parliament. ... It will also bring about a new conceptualisation of the judicial role, one that will have to try to explain the advisory opinion an indication of inconsistency would involve.

Despite this enthusiasm, which was shared by many lawyers and human rights advocates, the courts have yet to issue a declaration of inconsistency under the Bill of Rights Act. ${ }^{303}$ The closest the courts have come to issuing a declaration is the decision of Thomas $\mathrm{J}$ in Poumako in which he alone issues a declaration. While the Court of Appeal in Poumako appears to have accepted that declarations of inconsistency can be issued; the majority decided not to issue a declaration in that case. The general comments about the issuing of declarations of inconsistency from Thomas $\mathrm{J}$ in Poumako are insightful when considering the legitimacy of the jurisdiction, for example Thomas J, like Tipping J, makes a connection between s 5 of the Bill of Rights Act and declarations of inconsistency representing them as essential bedfellows:

The Bill of Rights was enacted to affirm fundamental rights and s 5 must be given a genuine role in relation to the interpretation of statutes. That role can be given effect to by the judiciary, and a declaration is the logical vehicle for doing so when such a course is required. ${ }^{304}$

The High Court in Zaoui v Attorney-General (Zaoui 2004) ${ }^{305}$ and Reid $v$ Minister of Labour (Reid) ${ }^{306}$ referred to the Court of Appeal decisions in Moonen (No.1) and Poumako as establishing authority for declarations of inconsistency, though in both of the High Court cases they determined it was not material to the outcome. In describing this authority, for example, Judge Williams in Zaoui states that: ${ }^{307}$

\begin{abstract}
...The main reason for taking that view is that this Court is bound by decisions of the Court of Appeal which, while not actually making a declaration of inconsistency, nonetheless clearly conclude jurisdiction exists. The cases include Moonen ...where the Court of Appeal set out a five-step test for determining inconsistency with BoRA including a final step in which clearly indicate courts may issue a declaration of inconsistency. ... And in $R v$
\end{abstract}

\footnotetext{
${ }^{303}$ Putting declarations issued by the Human Rights Review Tribunal's under the Human Rights Act 1993.

${ }^{304}$ Poumako, above n 57, at [97] per Thomas J.

${ }^{305}$ Zaoui v Attorney-General \& Anor [2004] 2 NZLR 339 [Zaoui (2004)].

${ }^{306}$ Reid $v$ Minister of Labour [2005] NZAR 125.

${ }^{307}$ Zaoui (2004), above n 305, at [166].
} 
Poumako [2000] 2 NZLR 695 the majority gave serious consideration to making a declaration of inconsistency with BoRA...

The Crown's position in relation to declarations of inconsistency is somewhat elusive. In Baigent's case the judgment of Hardie-Boys J notes that: "the SolicitorGeneral accepted that the Court could make a declaration that particular actions were in breach of its own provisions." ${ }^{308}$ While the Solicitor-General accepted this position in the respect of this case and the actions of State officials; subsequent Crown counsel have argued against this jurisdiction in relation to legislative provisions instead submitting that s 4 acts as a barrier to this jurisdiction. ${ }^{309}$ The counter to this argument is that s 4 of the Bill of Rights Act expressly sets out what the courts cannot do (invalidate or decline to apply a provision) and does not prohibit the issuing of declarations of inconsistency. For example, in his dissenting decision in Poumako, Justice Thomas states: ${ }^{310}$

It does not contravene the prohibition in s 4. ... Rather, it would serve to advance the very purposes of the Bill of Rights in that it would make it clear that a statutory provision of the kind in issue is clearly contrary to those objectives.

In contrast to the orthodox view of the courts that would see them not engaging on constitutional review of legislation because it encroaches on Parliament's lawmaking domain, it has been observed that being able to issue declarations of inconsistency would complement the courts' role under s 5 and is a practical judicial companion to reports issued by the Attorney-General under s 7 of the Bill of Rights Act. ${ }^{311}$ Butler and Butler observe that this is particularly the case for legislation that predates the Bill of Rights Act. Another argument often advanced in favour of declarations of inconsistency is that s 5 would be redundant without such a remedy. ${ }^{312}$ This is a less convincing argument given the broader constitutional role of the courts

\footnotetext{
${ }^{308}$ Baigent's Case, above n 41, at 698 per Hardie-Boys J.

${ }^{309}$ See Poumako, above n 57, at [91] per Thomas J; Boscawen v Attorney-General [2008] NZAR 468 (HC), above n 75, at [56]; Zaoui (2004), above n 305, at [165].

${ }^{310}$ Poumako, above n 57, at 94 per Thomas J.

${ }^{311}$ Butler and Butler The New Zealand Bill of Rights Act: A Commentary, above n 43, at 28.5.3. See also Poumako, above n 57, at [96] per Thomas J.

312 See Butler and Butler The New Zealand Bill of Rights Act: A Commentary, above n 43, at 28.5.5; and Poumako, above n 57, at [97] per Thomas J.
} 
pursuant to s 5 of the Bill of Rights Act: to promote transparency of parliamentary decisions.

Nevertheless, Judge McKenzie in Reid, like Judge Williams in Zaoui considered declarations of inconsistency to be a remedy of "last resort". ${ }^{313}$ Claudia Geiringer in her paper "An Update on Implied Declarations of Inconsistency and the New Zealand Bill of Rights Act" 314 examines five recent cases for their contribution to the development of this remedy and concludes while the decision in Hansen affirms that the courts have jurisdiction to review legislation for consistency with the Bill of Rights Act: "[t]he prospects for a formal remedial jurisdiction are, however, poor." 315

Geiringer reminds us that while the debate about whether courts can, and should, issue declarations of inconsistency is an abstract argument and that the procedural implications of such declarations limit the possibility of them being issued. Geiringer's paper identifies several procedural implications that need to be clarified by the courts and notes their approaches to them to date. For example, the Court of Appeal decisions in the Boscawen cases ${ }^{316}$ informs us that declarations cannot be issued in situations involving abstract review of legislation or covered by parliamentary privilege. $^{317}$ A plaintiff also needs to seek a declaration of inconsistency early in the proceedings to ensure that the earlier courts have the benefit of complete arguments from both sides. ${ }^{318}$ Whether declarations of inconsistency can be issued by District Courts or as part of criminal proceedings are also murky issues. ${ }^{319}$

These procedural complexities are sometimes cited as a reason why express legislative authority is required. ${ }^{320}$ An alternative view is that the practical implications identified by Geiringer above all suggest that the courts appear to be formulating the procedural requirements for declarations of inconsistency incrementally. It is desirable that the courts have a meaningful remedy for constitutional review and, to this end, if

\footnotetext{
${ }^{313}$ Reid, above n 306, at [19].

${ }^{314}$ Claudia Geiringer "Implied Declarations of Inconsistency and the New Zealand Bill of Rights Act: An Update" in Roderic Alley (ed) Celebrating Human Rights: Sixty Years of the Universal Declaration Proceedings of the Wellington Conference (New Zealand Institute of International Affairs and New Zealand Human Rights Commission, Wellington, 2009) [“An Update"]. The cases are: Taunoa $v$ Attorney-General [2006] NZSC 95; $R$ v Hansen [[2007] 1 NZLR 1; $R$ v Manawatu (2006) 23 CRNZ 833 and Christopher John Manawatu v R [2007] NZSC 13; Belcher v Chief Executive of the Department of Corrections [2007] 1 NZLR 507; and Boscawen v Attorney-General [2008] NZAR 468.

${ }^{315}$ Geiringer "An Update", above n 314, at 35.

316 Boscawen v Attorney-General [2008] NZAR 468 (HC) and Boscawen v Attorney-General [2009] 2 NZLR 229, above n 75.

${ }^{317}$ Geiringer "An Update", above n 314, at 33-34.

${ }^{318}$ Ibid, at 37.

${ }^{319} \mathrm{Ibid}$, at $36-37$.

${ }^{320}$ Poumako, above n 57, at [91] per Thomas J.
} 
we want declarations of inconsistency as a remedy anytime soon then New Zealand may, as identified by Geiringer, need to legislate for it. ${ }^{321}$

In summary, while the arguments around legal authority appear to be inconclusive when viewed in a strictly legal sphere; the constitution permits consideration of other factors. For example, despite the litigation strategies advanced by Crown counsel, the New Zealand Government in its Fourth Period Report to the United Nations Human Rights Committee listed, at paragraph 12, declarations of incompatibility as a remedy for a breach of the Bill of Rights Act citing the decision in Moonen as the source of the recent development and noting the minority declaration in Poumako in the Report. ${ }^{322}$ Not only has the government not moved to restrict the ability of the courts to develop remedies under the Bill of Rights Act; it has noted developments as positive endorsements of New Zealand's compliance with international human right standards. The Firth Periodic Report suggests that the extension of this jurisdiction to the Human Rights Review Tribunal for discrimination matters is to ensure that the Tribunal, whose jurisdiction is governed by legislation rather than a combination of legislation and common law, is a complementary amendment intended to ensure that the Tribunal could also exercise this power. ${ }^{323}$

As with the question of whether it is legitimate the courts should review legislation under the Bill of Rights Act the legitimacy of the courts issuing declarations of inconsistency is also frequently debated when analysing the merits of such a remedy for unjustified breaches of the Bill of Rights Act. The legitimacy of the courts issuing declarations of inconsistency again goes to the heart of the evolving role of the courts and their contribution to the affirmation and protection of human rights. For example, Crown counsel in Poumako and Boscawen submitted that if the courts were to issue a declaration of inconsistency then it would upset the "delicate relationship" between the courts and Parliament. ${ }^{324}$

Issuing a declaration seems a natural conclusion to a finding that a legislative provision is an unjustified limit on a right. And yet, the courts seem reluctant to issue one. This is evident from the Supreme Court's decision in Hansen, despite a majority reaching the conclusion that s 6(6) of the Misuse of Drugs Act is an unjustified

\footnotetext{
${ }^{321}$ Geiringer "An Update", above n 314, at 44.

${ }^{322}$ New Zealand Government Fourth Period Report to the United Nations Human Rights Committee under the International Covenant on Civil and Political Rights CCPR/C/NZL/2001/4 (May 2001) at [18].

${ }^{323}$ New Zealand Government Fifth Period Report to the United Nations Human Rights Committee under the International Covenant on Civil and Political Rights CCPR/C/NZL/2007 (21 December 2007).

${ }_{324}$ Poumako, above n 57, at [91] per Thomas J; and Boscawen v Attorney-General [2008] NZAR 468 (HC), above n 75, at [8].
} 
limitation on the right to be presumed innocent as affirmed in s 25(c) of the Bill of Rights Act and that the provision must stand and be applied by virtue of s 4 of the Bill of Rights Act. As Geiringer notes in her update on declarations of inconsistency, the appellant's counsel had requested in their written submissions that the Supreme Court issue a declaration but the judges do not discuss the question of declaratory relief in the decision. $^{325}$

The reluctance of the courts to issue declarations of inconsistency appears to hinge on a wariness of upsetting the orthodox view unless the matter severely impinges on the Bill of Rights Act and the constitution, or if the limitation is oppressive of a wide cross-section of society. While the issuing of declarations of inconsistency may challenge the orthodox view it does not undermine the constitution instead it is a way of balancing the institutional weakness of Parliament and using the institutional advantages of the courts: ${ }^{326}$

When the Courts issue a declaration of inconsistency, parliamentary sovereignty is left intact: the Courts are not refusing to apply the legislation, as that would be tantamount to usurping parliamentary sovereignty. Parliament retains supreme authority to dictate changes to legal policy.

As identified by Conte and Wynn-Williams, declarations of inconsistency are a mechanism for informing Parliament that it has fallen short of the legislative standards it has set out in the Bill of Rights Act. ${ }^{327}$ Furthermore, the use of declarations of inconsistency, rather than subverting the objective of the legislative provision by reading down the limit, is a demonstration of judicial deference to the law-making role of Parliament: ${ }^{328}$

... the fundamental constitutional principle of judicial independence exists to ensure that this function is impartially and fearlessly exercised. In being judicially circumspect to the legislative primacy of Parliament, therefore, the courts must guard against being too sensitive to the supposed reaction of that institution when exercising the judicial function. This judicial independence is not, of course, antithetical to Parliament's legislative sovereignty. As already emphasised, Parliament can pass legislation to overrule the courts. Indeed,

\footnotetext{
${ }^{325}$ Geiringer "An Update", above n 314, at 39.

${ }^{326}$ Conte and Wynn-Williams "Declarations of inconsistency" above n 32, at 251.

${ }^{327}$ Ibid.

${ }^{328}$ Poumako, above n 57, at [103] per Thomas J (dissenting).
} 
following a declaration of the kind I envisage, Parliament can choose to leave the proscribed provision in place, or even to reinforce it. That choice is Parliament's prerogative. Its legislative sovereignty remains intact.

An argument can also be made that the courts, in issuing a declaration of inconsistency, are essentially giving a particular person or sector of the community an extra and, therefore, undemocratic vote in the matter. ${ }^{329}$ Fredman has a different take on this in relation to the UK Human Rights Act, instead characterising declarations of inconsistency in terms of deliberative democracy: ${ }^{330}$

The HRA can be characterised in terms of deliberative democracy. On the one hand, because judges have no power to invalidate legislation, a decision in favour of an excluded group is not a veto over representative decision-making. Instead the effect of a judicial decision is to signal to legislators that the political process should be re-opened.

Such a declaration gives Parliament the opportunity "to make a deliberative, authoritative, and informed decision whether to address a legislative incursion on fundamental rights and freedoms." 331

A more controversial question is perhaps not whether the courts can and should issue declarations of inconsistency but whether they are under a duty to do so. ${ }^{332}$ For example, could a decision be challenged for not issuing a declaration of inconsistency? This is a question for another paper and is a challenging one because the evolving constitutional role of the courts could see this question being addressed presently or not for another decade depending on the nature of cases that comes before it; unless this is a matter that the government will be considering as part of its review of constitutional arrangements in which case it could be resolved in the near future. ${ }^{333}$

It is noteworthy that Parliament has not enacted an amendment to the Bill of Rights Act clearly stating, in similar terms to s 4 of the Bill of Rights Act, that declarations of inconsistency are not permitted: ${ }^{334}$

\footnotetext{
${ }^{329}$ Fredman "From Deference to Democracy", above n 279, at 69-70.

${ }^{330}$ Fredman "From Deference to Democracy", above n 279, at 70.

${ }^{331}$ Conte and Wynn-Williams "Declarations of inconsistency" above n 32, at 252.

332 Ibid, at 253-254.

${ }^{333}$ Prime Minister John Key, above n 82.

${ }^{334}$ Conte and Wynn-Williams "Declarations of inconsistency" above n 32, at 254.
} 
Irrespective of whether declaration of inconsistency are seen as contrary to Parliament's intention, in Diceyan constitutional terms, it is of course open to Parliament to limit or override the Judge-made law which emerges from the Courts.

Despite the rumblings in various judgments over the last 10 years about the possibility of such a remedy being plausible, no action to amend the Bill of Rights Act has been taken. The Foreshore and Seabed Act 2004 as a response to the decision in Ngati Apa v Attorney-General ${ }^{335}$ is a clear and relatively recent example of Parliament taking just such action where they consider that the courts should not have jurisdiction to consider some matters. In the case of the Bill of Rights Act, however, the Government of the day has instead noted such declarations as potential remedy in reports about New Zealand's compliance with international human rights standards to the United Nations Human Rights Committee.

When contemplating whether such declarations are necessary or make a difference; bear in mind the fact, as observed by Geiringer in her update, that a declaration of inconsistency changes the "winner" of the case to that of the applicant: "This has, most significantly, costs implications, as well, perhaps, as implications for the availability of legal aid. It would therefore have a significant impact on the practical availability of the remedy." 336 Furthermore, the declaration would have the effect of promoting the right within New Zealand and acting as guidance to the executive and legislative branches about what intrusions are unlikely to be justified and to improve the rigours of the policy work to ensure such intrusions are indeed supported by evidence and clear reasoning not simply an automatic, panicked, or popular response to a policy problem.

Therefore, in light of the incremental approach taken by the courts in developing the remedy of declarations of inconsistency, the common law heritage for developing remedies to rights, the attitude of the government to the remedy, together with the fact that the government has not amended the Bill of Rights Act to remove the ability for the courts to issue declarations of inconsistency it would appear that the courts can legitimately issue declarations of inconsistency as a constitutional review remedy.

\footnotetext{
${ }^{335}$ Ngati Apa v Attorney-General, above n 100.

${ }^{336}$ Geiringer "An Update", above n 314, at 42.
} 


\section{NEW CONSTITUTIONAL PARADIGM}

The analysis of the legal authority and how the courts perform constitutional review reveals that while it challenges the orthodox position, it is consistent with the constitution and does not undermine the Parliament's position as the ultimate lawmaker or its ability to make and unmake laws. It is, therefore, timely to revisit the orthodox view because not only does constitutional review of legislation not undermine Parliament but also constitutional review is part of constitutional evolution that will see the strengthening of democracy in New Zealand. New Zealand appears ready to shed the orthodox view for a more transparent and sophisticated model of legislative accountability than that that offered by periodic general elections. It is essential to recall that cases are bought by people who disagree with the law; the courts are not self referring and review of legislation is not performed in the abstract. The courts are another way for people to challenge the legitimacy of laws without, in the case of the Bill of Rights Act, undermining the application of those laws and maintaining New Zealand's constitutional norm of a strong representative democracy. ${ }^{337}$ As noted earlier, Palmer describes New Zealand constitutional culture as having three values: egalitarianism, authoritarianism, and pragmatism; these values offer a sound basis for considering a different constitutional paradigm for New Zealand. ${ }^{338}$

\section{Conceptual weakness with the orthodox view}

The orthodox view of parliamentary sovereignty is itself afflicted by many of the conceptual challenges that constitutional review of legislation faces - particularly in that it has both legal and political dimensions: ${ }^{339}$

In spite of the law of written constitutional limits on the United Kingdom Parliament, it has long been recognised that there are certain measures that it would be politically impossible to adopt and whose enactment would, therefore, never be attempted.

This observation by Elliot, in relation to the United Kingdom, highlights that the lawmaking power of Parliament is not "unlimited" in a constitutional sense; it is subject to non-legal limitations. The orthodox view of the doctrine of parliamentary

\footnotetext{
${ }^{337}$ Palmer "New Zealand Constitutional Culture", above n 25, at 580-581.

${ }^{338}$ Ibid, 575-578.

${ }^{339}$ Elliot "United Kingdom: parliamentary sovereignty under pressure", above n 21, at 546.
} 
sovereignty's focuses on the form of the law; that is by virtue of Parliament passing a law it is valid. ${ }^{340}$ A law passed by Parliament is valid because it is made of democratically elected representatives who are intended to reflect the views and values of the people. This view is somewhat simplistic, however, as it overlooks the fact that democracy is not just a mode of governance but also a reflection of values (such as equality) and that there are essential substantive elements to democracy.

It is plausible that the rise and stability of representative democracy in common law jurisdictions such as the United Kingdom, New Zealand, Canada, and Australia, during the late $19^{\text {th }}$ century and early $20^{\text {th }}$ century saw, initially at least, a reduced need for this protective function by the courts that was served by common law principles such as the Bonham principle. ${ }^{341}$ However, there seems to be an increasing willingness by the courts to perform "value driven" review. ${ }^{342}$ Jeffrey Jowell in writing about the United Kingdom, attributes the increase of review of legislation and review of administrative decisions to a desire to place limits on government's power and that this desire is a reaction to "the great tyrannies of the $20^{\text {th }}$ century [that] had already demonstrated the dangers of unconfined power, regardless of whether it was sanctioned by popular consent. ${ }^{\$ 343}$

Constitutional review is a new area and the parameters of the theory in New Zealand are still fluid and as Joseph concludes in his discussion of constitutional review: "Recognition of the new grounds would promote the courts' practices openly, with broad acceptance, and would infect our public law with greater ethical and moral content. ${ }^{344}$ In a later article about judicial indications of inconsistency Andrew Butler discusses the Court of Appeal's decision in Moonen (No 1). ${ }^{345}$ In the course of this article, Butler locates Moonen (No 1) in modern New Zealand public law discourse focusing on Rishworth's estimation, in 1996, that the Bill of Rights Act would mark a

\footnotetext{
${ }^{340}$ Burrows and Carter Statute Law in New Zealand, above n 84, at 22.

${ }^{341}$ In Dr Bonham's Case (1610) 8 Co Rep 107, 77 ER 638, is in essence that some common law rights are so entrenched that even Parliament can not override them. See Karen Grau, "Parliamentary Sovereignty: New Zealand - New Millennium" (2002) 33 VUWLR 351 - her discussion of the New Zealand decisions which suggest that this principle is in reserve should it be required is illustrative: $L v$ $M$ [1979] 2 NZLR 519 (CA) at 527 per Cooke J; Brader v Ministry of Transport [1981] 1 NZLR 73 (CA) at 78 per Cooke J; New Zealand Drivers Association v New Zealand Road Carriers [1982] 1 NZLR 374 at 390 per Cooke J; Fraser v State Services Commission [1984] 1 NZLR 116 (CA) at 121 per Cooke J; and Taylor v New Zealand Poultry Board [1984] 1 NZLR 394 (CA) at 398 per Cooke J.

${ }^{342}$ A Butler "Judicial Indications of Inconsistency", above n 32, at 58.

343 Jeffrey Jowell "Parliamentary sovereignty under the new constitutional hypothesis" [2006] Public Law 562 at 578 ["Parliamentary sovereignty"].

344 Joseph "Constitutional Review Now", above n 3, at 128.

${ }^{345}$ A Butler "Judicial Indications of Inconsistency", above n 32.
} 
shift in the emphasis of public law $^{346}$ and draws attention to Joseph's discussion of constitutional review: ${ }^{347}$

In a recent challenging paper Phillip Joseph has traced the beginnings of a new constitutional review paradigm in New Zealand, which is "values driven" and substantive, aimed at vindicating basic constitutional and human rights standards. This can be contrasted with the traditional approach, which has concentrated on process. ... In my view, if the Court of Appeal follows through with the concept of "judicial indications of inconsistency" we will be witnessing a profound paradigm shift in New Zealand public law discourse that builds upon the elements identified by both Rishworth and Joseph.

While some commentators observe with these developments gentle anticipation, there is disquiet amongst others about the developing jurisdiction of constitutional review. For example, Ekins asks whether New Zealand is in the middle of a quiet revolution lead by an activist judiciary to limit the government's power and whether the courts are the appropriate body to lead such a revolution. ${ }^{348}$ The debate about the constitutionality of such review is often made in binary terms: parliamentary sovereignty versus judicial supremacy. The United States of America is an example of judicial supremacy in which the courts have the final say: ${ }^{349}$

The Bill of Rights gives the US Supreme Court the final word on the issues that come before it. As the Supreme Court stressed in Marbury v Madison "it is, emphatically, the province and duty of the judicial department, to say what the law is". ... A rule of the Supreme Court cannot be superseded by legislation enacted by Congress (however controversial): but requires a constitutional amendment.

Canada is described as having a "weaker" form of judicial supremacy because while the courts can strike down legislation that is inconsistent with the Canadian Charter, Parliament can expressly reserve its position under s 33 of the Canadian Charter for some rights, and the courts must also apply a justified limitations test under

\footnotetext{
${ }^{346}$ A Butler "Judicial Indications of Inconsistency", above n 32, at 58 quoting from Rishworth "Human Rights and Bill of Rights", above $n 32$.

347 A Butler "Judicial Indications of Inconsistency", above n 32, at 58.

${ }^{348}$ Ekins "The Authority of Parliament", above n 17, at 65.

${ }^{349}$ Clayton "Judicial deference", above n 284.
} 
s 1 of the Canadian Charter. ${ }^{350}$ In contrast, New Zealand has a Bill of Rights Act that expressly preserves legislative supremacy.

In relation to the New Zealand courts and judicial activism, Hon Dr Michael Cullen asserted that if constitutional change is to occur then it should be the subject of a democratic process with broad public involvement rather than through judicial development of constitutional law that would see the application of a higher law approach in constitutionally significant areas. ${ }^{351}$ Petra Butler's article "Human Rights and Parliamentary Sovereignty in New Zealand" provides an alternative perspective about whether the courts are taking an activist approach to human rights cases thereby impinging on the doctrine of parliamentary sovereignty. ${ }^{352}$ Judicial activism is defined, in the article, as a judge drawing on his or her moral, political, or religious views as to what the law should be. Petra Butler concludes that courts have not deprived Parliament of its sovereignty ${ }^{353}$ and that "the courts role has become more overtly that of Parliament's partner in law making."354

The binary approach of legislative supremacy versus judicial supremacy is unsophisticated and fails to acknowledge the complementary relationship between Parliament and the courts; especially, given s 4 of the Bill of Rights Act expressly retains the legislative and democratic mandate of Parliament. It is necessary, therefore, to develop a paradigm that better describes the productive relationship between the courts and Parliament.

\section{$2 \quad$ Alternative paradigms for the relationship between Parliament and the courts}

In practical terms, the orthodox view is no longer supportable in the New Zealand context due, in part, to the Supreme Court's decision in Hansen that definitively establishes the courts role to review legislation for consistency with the Bill of Rights Act. This role has not been contradicted by a legislative amendment to the Bill of Rights Act; instead the mode of analysis has been employed by the government to assess whether draft legislation is consistent with the Bill of Rights Act. If the orthodox view is no longer supportable then the two obvious starting points for alternative paradigms are Joseph's collaborative enterprise framework and Hogg and Bushell's dialogue theory. Before examining these theories it is important to recall that

\footnotetext{
${ }^{350}$ Hogg, Thornton and Wright "Charter Dialogue Revisited", above n 111, at 3.

${ }^{351}$ Hon Dr Michael Cullen "Parliamentary Sovereignty and the Courts" (2004) NZLJ 243. Dr Cullen was the Attorney-General, Deputy Prime Minister, and Leader of the House at the time this article was published.

${ }^{352}$ P Butler "Human Rights and Parliamentary Sovereignty in New Zealand", above n 32.

${ }^{353}$ Ibid, at 365 .

${ }^{354}$ Ibid, at 341 .
} 
any such alternative, in relation to the Bill of Rights Act, has a set parameter: the courts cannot override or refuse to apply a provision simply because it is an unjustified limitation on a right (s 4 of the Bill of Rights Act). This parameter reflects two of New Zealand's enduring constitutional cultural values: egalitarianism and authoritarianism. 355

In 1997, Hogg and Bushell set out to confront the anti-majoritarian objection to the legitimacy of review of legislation under the Canadian Charter and also developed a new paradigm for examining the relationship between Parliament and the courts: the dialogue theory. While the design of the Bill of Rights Act was influenced by the Canadian Charter there are a differences between the two instruments the material one, in this instance, is that the courts in Canada have the power to strike down legislation that places an unjustified limitation on the rights and freedoms contained in the Canadian Charter. Nevertheless, the similarities make it useful to examine the dialogue theory as this theory has been used to describe the relationship between the courts and Parliament in other common law jurisdictions. This theory offers a non-legal description of the relationship between Parliament and the courts in relation to promoting human rights and democratic values. The hypothesis that Hogg and Bushell worked with was that: ${ }^{356}$

...while the Charter would often influence the design of legislation that encroached on a guaranteed right, it would "rarely [raise] an absolute barrier to the wishes of the democratic institutions." Legislatures would retain the primary responsibility for social and economic policy, and would usually be able to accomplish what they wanted to do while respecting the requirements of the Charter.

In essence, when a court strikes down legislation it is said to be starting a dialogue with Parliament about where the balance lies between the right and the public interest in pursuing a particular policy objective. Hogg and Bushell examined all the relevant decisions and concluded that a court's decision is not "the last word" and that: "while the Charter had given judges considerable authority to curtail legislative actions that impinged on protected rights and freedoms, it had by no means ousted majoritarian will. $^{357}$

\footnotetext{
${ }^{355}$ Palmer "New Zealand Constitutional Culture", above n 25, at 575-578.

${ }^{356} \mathrm{Hogg}$, Thornton and Wright "Charter Dialogue Revisited", above n 111, at 3.

${ }^{357}$ Ibid, at 4 .
} 
The dialogue theory has subsequently generated much discussion and debate and in 2007 the Osgoode Hall Law Journal invited the authors and other academics and commentators to contribute to a further examination of the theory. As part of this the original authors, joined by Wright, reviewed further decisions by the Supreme Court of Canada to strike down legislation and examined the critique of the dialogue theory. They concluded that the anti-majoritarian objection remains a weak one given the way in which Parliament and the courts respond to such decisions, and observed five ways in which the judges of the Supreme Court of Canada have employed the dialogue theory such as invoking the idea of dialogue to justify judicial review and to oppose the reading down of legislation in a Canadian Charter case. ${ }^{358}$ Reference of the dialogue theory by the courts reflects a desire to find a better way of describing the relationship between Parliament and the courts because the courts have had to evolve in response to legislative measures taken by Parliament to improve the observance of human rights standards and democratic values. This desire is not limited to Canada it is also present in case law from the United Kingdom and New Zealand where, although there is no power to strike down legislation, the courts are performing a role in which they critique Parliament thus bringing them into competition with the orthodox view.

In his article "Parliament, the Courts, and the Collaborative Enterprise", Joseph seeks to discover the true nature of the relationship between Parliament and the courts, and expressly rejects the binary construction of parliamentary supremacy versus judicial supremacy instead relying on the concept of a collaborative enterprise in which the roles of the respective institutions in the business of government are interdependent but remain independent. ${ }^{359}$ Joseph rejects the normative force of the language of "sovereignty" and "supremacy" and asserts that neither branch is supreme over the other. ${ }^{360}$ Instead, Joseph identifies that although Parliament and the courts gain their legitimacy through different means (Parliament through representative democracy and the courts through the constitution and common law) their goal is the same: "[t]he continuing mutual respect and goodwill between these branches vouchsafe liberties and freedoms in a representative democracy.",361

Nevertheless, some prudence is required because while the concept of "sovereignty" and "supremacy" appears outmoded, the kernel of the doctrine of parliamentary sovereignty that places Parliament as the ultimate lawmaker is still at the

\footnotetext{
${ }^{358}$ Ibid, at 52-53.

359 Philip Joseph "Parliament, the Courts, and the Collaborative Enterprise" (2004) 15 KCJL 321330. See also Jowell "Parliamentary sovereignty", above n 344, at 576.

${ }^{360}$ Joseph "Parliament, the Courts, and the Collaborative Enterprise", above n 360, at 323.

${ }^{361}$ Joseph "Parliament, the Courts, and the Collaborative Enterprise", above n 360, at 345.
} 
heart our constitutional arrangements due to our constitutional cultural values of egalitarianism and authoritarianism. The material change bought by constitutional review of legislation reflects a third constitutional cultural value: pragmatism. This is because constitutional review presents an invaluable avenue for the public to challenge Parliament's direction when they disagree with the position Parliament has taken. It is an opportunity to hold Parliament accountable for its choices and to ensure transparency of decision-making. This avenue is necessary to counteract the institutional weakness of Parliament (majority rule) using the institutional advantages of the courts (impartial and independent decision making). The outcome of a judicial decision that a legislative provision is an unjustified limitation does not have direct legal consequences; it has political consequences. This is a reflection of our current legal and constitutional context; Joseph's collaborative enterprise framework does, however, recognise iterative constitutional growth and reflect New Zealand's continuing incremental movement towards a constitutional model that places constructive limits on the power of Parliament and government. 


\section{CONCLUSION}

Despite the differing views about the legitimacy of the courts performing review of legislation, the courts have been reviewing legislation under the auspices of $\mathrm{s}$ 5 of the Bill of Rights Act without intervention of Parliament. Moreover, as this paper demonstrates, constitutional review of legislation can be performed consistently with the constitution. The courts largely perform their role within the orthodox view when interpreting the right and assessing the nature of the infringement of the limit on the right. There are, nonetheless, aspects of constitutional review of legislation that encroach on the orthodox view particularly when the courts assess whether the objective is important and significant, whether there are alternative policy options, and whether the paramount balance has been struck between the competing public interests in applying the proportionality analysis. This encroachment does not, however, undermine the ability for Parliament to make and unmake laws or result in the striking down of legislation by the courts; Parliament's position at the apex of the constitutional structure is retained by virtue of section 4 of the Bill of Rights Act. ${ }^{362}$ Furthermore, the cautious use of proportionality analysis, and judicial deference and restraint will ensure that comity between the courts and Parliament is maintained.

Constitutional review of legislation is an integral part of achieving the purpose of $s$ of the Bill of Rights Act: to promote a culture of justification and accountability in relation to the democratic values the New Zealand has enacted in the Bill of Rights Act. It is a means of the New Zealand public challenging Parliament and seeking it to reconsider, using an actual instance of a rights infringement, the legal position it has taken on a policy matter. While this is a new role or the courts; it is not an unfamiliar one and is an extension of the current practices of judicial review of administrative decisions. Judicial review of legislation under the Bill of Rights Act is, therefore, not only "constitutional" but is instrumental in furthering the goals of democracy, particularly in the absence of a codified constitution because the values protected by the rights in the Bill of Rights Act are democratic values: one of the substantive constitutional benchmarks against which Parliament's decisions should be measured.

While judicial deference and restraint to Parliament has a role to play in judicial decision-making to preserve comity between the courts and Parliament; it should not be used to circumvent the proportionality analysis. The courts should be encouraged to

\footnotetext{
${ }^{362}$ A Butler "The Bill of Rights Debate", above n 16, at 340: "By contrast, parliamentary sovereignty is the principle that Parliament is the apex of the constitutional structure: it is the source of supreme law and has ultimate power to determine what will and what will not be law."
} 
issue declarations of inconsistency so that constitutional review of legislation can have a meaningful remedy to advance greater debate about the merits of a particular political response to a social or legal problem (although encouragement may need to come in the form of legislation if desired sooner rather than later).

Not only is New Zealand's constitution the result of pragmatic evolution; it also reflects the characteristics of New Zealanders themselves, as described by Michael King in Penguin History of New Zealand: ${ }^{363}$

...most New Zealanders, whatever their cultural background, are good-hearted, practical, commonsensical and tolerant. Those qualities are part of the national character that has in the past saved this country from the worst excesses of chauvinism and racism seen in other parts of the world. They are as sound a basis as any for optimism about the country's future.

Constitutional review of legislation under the Bill of Rights Act is a pragmatic response to a growing desire to improve the transparency of decision-making by Parliament. Constitutional review of legislation reflects not only the constitutional value of pragmatism it also it sees a shift towards a more sophisticated form of representative democracy in which the views of minority or marginalised groups can be given an airing when a law has a disproportionate effect them without undermining parliamentary sovereignty.

${ }^{363}$ Michael King The Penguin History of New Zealand (Auckland, Penguin Books, 2003) at 520. 


\section{BIBLIOGRAPHY}

\section{A Primary Sources}

$1 \quad$ New Zealand case law

Boscawen v Attorney-General [2008] NZAR 44 (HC).

Boscawen v Attorney-General [2008] NZAR 468 (HC).

Boscawen v Attorney-General [2009] 2 NZLR 229 (CA).

Belcher v Chief Executive of the Department of Corrections [2007] NZSC 54.

Belcher v Chief Executive of the Department of Corrections [2007] 1 NZLR 507 (CA).

Belcher $v$ Chief Executive of the Department of Corrections [2007] NZCA 174 (CA).

Hansen v R [2007] NZSC 7.

Mangawaro Enterprises Ltd v Attorney-General (HC, Wellington) 9 Dec 1993, CP278/93.

Ministry of Transport $v$ Noort (Police v Curran) [1992] 3 NZLR 260 (CA).

Moonen v Film and Literature Board of Review [2000] 2 NZLR 9 (CA).

Moonen v Film and Literature Board of Review [2002] 2 NZLR 754 (CA).

Ngati Apa v Attorney-General [2003] 3 NZLR 643 (Maori Land Court).

Quilter v Attorney-General [1998] 1 NZLR 523 (CA).

$R v$ Manawatu (2006) 23 CRNZ 833.

$R v$ Poumako [2000] 2 NZLR 695 (CA).

Reid v Minister of Labour [2005] NZAR 125 (HC).

Simpson v Attorney-General (Baigent's case) [1994] 3 NZLR 667 (CA).

Taunoa \& Ors v Attorney-General \& Anor [2006] NZSC 95.

Taunoa \& Ors v Attorney-General [2007] NZSC 70.

Temese v Police (1992) CRNZ 425 (CA).

Zaoui v Attorney-General \& Anor [2004] 2 NZLR 339.

$2 \quad$ New Zealand legislation

Acts Interpretation Act 1924.

Bill of Rights 1688 .

Constitution Act 1986.

Interpretation Act 1999.

Imperial Laws Application Act 1988.

Misuse of Drugs Act 1976.

New Zealand Bill of Rights Act 1990.

3 Case law from other jurisdictions

Dr Bonham's Case (1610) 8 Co Rep 107, 77 ER 638.

Heydon's Case (1584) 3 Co Rep 7a (EWHC Exch).

International Transport Roth Gmbh v Secretary of State for the Home Department [2003] QB 728.

Jackson v Attorney-General [2005] UKHL 56.

$M \vee H[1999] 2$ SCR 3. 
Marbury v Madison 1 Cranch 137 (1803).

Minister of Home Affairs v Fisher [1980] AC 319.

$R v$ Big M Drug Mart Ltd [1985] 1 SCR 295.

$R v$ Chaulk [1990] 3 SCR 1303.

$R v$ Edward Books and Art [1986] 2 SCR 713.

$S v$ Coetzee (1997) 3 SA 527.

Thomson Newspapers Co v Canada (Attorney-General) [1998] 1 SCR 877.

Thoburn v Sutherland City Council [2002] 4 All ER 156.

Vriend v Aberta [1998] 1 SCR 493.

$4 \quad$ Legislation from other jurisdictions

Canada Act 1982 (UK) RS C 1982 Schedule B, Part 1.

Human Rights Act 1998 (UK).

\section{B Secondary Materials}

1 Texts and other official sources

Burrows, JF and Carter, RJ Statute Law in New Zealand (LexisNexis, Wellington, 2009).

Butler, Andrew and Butler, Petra The New Zealand Bill of Rights Act: A Commentary (LexisNexis, Wellington, 2005).

Cabinet Office Cabinet Manual 2008.

Constitutional Arrangements Committee Inquiry to Review New Zealand's Existing Constitutional Arrangements: Report of the Constitutional Arrangements Committee [2005] AJHR I.24A.

Davies, Margaret Asking the law question (The Law Book Company Limited, Australia, 1994).

Dicey, A V An introduction to the study of the Law of the Constitution ( $8^{\text {th }}$ ed, Macmillan, United Kingdom, 1996).

Hogg, Peter (ed) Constitutional Law of Canada (Looseleaf ed, vol 2, 1997).

Justice and Law Reform Committee Interim Report of the Justice and Law Reform Committee, Inquiry into the White Paper - A Bill of Rights for New Zealand [1986-1987] X AJHR I.8A.

Justice and Law Reform Committee Final Report of the Justice and Law Reform Committee on a White Paper - A Bill of Rights for New Zealand [1987-1990] XVII AJHR I.8C.

King, Michael The Penguin History of New Zealand (Auckland, Penguin Books, 2003).

Joseph, Philip Constitutional and Administrative Law in New Zealand ( $3^{\text {rd }}$ ed, Brookers, Wellington, 2007).

Law Commission Crown Liability and Judicial Immunity: a response to Baigent's case and Harvey v Derrick (NZLC R37, 1997).

Ministry of Justice The Guidelines On The New Zealand Bill Of Rights Act 1990: A Guide To The Rights And Freedoms In The Bill Of Rights Act For The Public Sector (Wellington, 2004).

New Zealand Government Fourth Period Report to the United Nations Human Rights Committee under the International Covenant on Civil and Political Rights CCPR/C/NZL/2001/4 (May 2001).

New Zealand Government Fifth Period Report to the United Nations Human Rights Committee under the International Covenant on Civil and Political Rights CCPR/C/NZL/2007 (21 December 2007).

New Zealand Government New Zealand National Universal Periodic Review Report to the Human 
Rights Council A/HRC/WG.6/5/NZL/1 (9 April 2009).

Palmer, Geoffrey “A Bill of Rights for New Zealand: A White Paper” [1984-1985] I AJHR A6.

International Law Association "The Paris Minimum Standards of human rights norms in a state of emergency” (1985) 79 American journal International Law 1072.

Prime Minister John Key "Statement to Parliament" (Statement to Parliament, 9 February 2010).

Rishworth, Paul (ed) The New Zealand Bill of Rights (Oxford University Press, Melbourne, 2002).

United Nations Human Rights Committee Consideration of reports submitted by States Parties under article 40 of the Covenant: concluding observation of the Human Rights Committee: New Zealand, 7 August 2002, CCPR/CO/75/NZL.

United Nations Sub-Commission on Prevention of Discrimination and Protection of Minorities Siracusa Principles on the Limitation and Derogation of Provisions in the International Covenant on Civil and Political Rights (1984) UN Doc E/CN.4/1984/4 Annex.

$2 \quad$ Journal articles

Allan, TRS "The Constitutional Foundations of Judicial Review: Conceptual Conundrum or Interpretative Inquiry” (2002) 61(1) Cambridge Law Journal 87.

Alexy, Robert “Balancing, Constitutional Review, and Representation” 3 Int'1 J Const L 572.

Brookfield, F M “Constitutional Law” [1992] NZ Recent Law Review 231.

Brookfield, F M “Constitutional Law” [1993] NZ Recent Law Review 278.

Butler, Andrew "Judicial Indications of Inconsistency - a New Weapon in the Bill of Rights Armoury?" [2000] New Zealand Law Review 43.

Butler, Andrew "Strengthening the Bill of Rights" (2000) 31 VUWLR 129.

Butler, Andrew "The Bill of Rights Debate: Why the New Zealand Bill of Rights Act 1990 is a Bad Model for Britain" (1997) 17 OJLS 323.

Butler, Petra "Human Rights and Parliamentary Sovereignty in New Zealand" (2004) 35 VUWLR 341.

Butler, Petra “Student Companion R v Hansen [2007] NZSC 7” [2007] NZLJ 47.

Clayton, Richard "Judicial deference and "democratic dialogue": the legitimacy of judicial intervention under the Human Rights Act 1998” (2004) SPR Public Law 33-47.

Conte, Alex and Wynn-Williams, Sarah "Declarations of inconsistency under the Bill of Rights. Part I: judicial jurisdiction, discretion or obligation?” (2003) 6(3) Human Rights Law \& Practice 243.

Conte, Alex "Declarations of inconsistency under the Bill of Rights. Part II: an "effective remedy"? (2003) 6(3) Human Rights Law \& Practice 256.

Comella, Victor Ferreres "The European model of constitutional review of legislation: toward decentralisation?” (2004) 2(3) I CON 461.

Craig, Paul "The Courts, the Human Rights Act and Judicial Review" (2001) 117 Law Quarterly Review 589.

Cullen, Hon Dr Michael "Parliamentary Sovereignty and the Courts" (2004) NZLJ 243.

Curran, Chris and Kirkness, Robert "Deference in a Bill of Rights Act context" (paper presented to LexisNexis Professional Development Public Law Conference, 2009). 
Czarnota, Adam "Wojciech Sadurski, Rights Before Courts: A Study of Constitutional Courts in Postcommunist States of Central and Eastern Europe.” (2005) 5 Int'l Journal of Constitutional Law 568. Ekins, Richard "The Authority of Parliament. A reply to Professor Joseph" (2005) 16 KCLJ 51.

Elliot, Mark “United Kingdom: parliamentary sovereignty under pressure” (2004) 2 Int'1 Journal of Constitutional Law 545.

Ferguson, Gillian “Dignity before Deference: An Alternative to Quilter" (2000) 5 Human Rights Law and Practice 263.

Fredman, Sandra "From Deference to Democracy: The role of Equality under the Human Rights Act" (2006) 122 Law Quarterly Review 53.

Geiringer, Claudia “The Dead Hand of the Bill of Rights? Is the New Zealand Bill of Rights Act 1990 a Substantive Legal Constraint on Parliament's Power to Legislate?” (2007) 11(3) Otago Law Review 389. Claudia Geiringer "Implied Declarations of Inconsistency and the New Zealand Bill of Rights Act: An Update" in Roderic Alley (ed) Celebrating Human Rights: Sexty Years of the Universal Declaration Proceedings of the Wellington Conference (New Zealand Institute of International Affairs and New Zealand Human Rights Commission, Wellington, 2009).

Grau, Karen "Parliamentary Sovereignty: New Zealand - New Millennium” (2002) 33 VUWLR 351.

Guarnieri, Carlo "Courts and Marginalized Groups: Perspectives from Continental Europe" 5 Int'1 Journal of Constitutional Law 187.

Gordon, Michael "The Conceptual Foundations of Parliamentary Sovereignty: Reconsidering Jennings and Wade" [2009] Public Law 519.

Harlow, Carol "Damages and Human Rights” [2004] NZ Law Review 429.

Henaghan, Mark "Same-sex Marriages in the Court of Appeal” [1998] NZLJ 40.

Hogg, Peter and Bushell, Allison "The Charter Dialogue Between Courts and Legislatures (Or perhaps the Charter of Rights isn't such a bad thing after all)" (1997) 35 Osgoode Hall LJ 75.

Hogg, Peter; Bushell Thornton, Allison; and Wright, Wade "Charter Dialogue Revisited--Or "Much Ado About Metaphors" (2007) 45 Osgoode Hall LJ 1.

Hogg, Peter; Bushell Thornton, Allison; and Wright, Wade "A Reply on "Charter Dialogue Revisited" (2007) 45 Osgoode Hall LJ 193.

Huscroft, Grant “Constitutionalism from the Top Down”(2007) 45 Osgoode Hall LJ 91.

Joseph, Philip “Constitutional issues: $R$ v Poumako a potpourri of constitutional issues” [2000] NZ Law Review 313.

Joseph, Philip “Constitutional Review Now” [1998] NZ Law Review 85.

Joseph, Philip “Constitutional Law” [2006] NZ Law Review 123.

Joseph, Philip "Parliament, the Courts, and the Collaborative Enterprise" (2004) 15 KCJL 321.

Jowell, Jeffrey “Judicial deference: servility, civility or institutional capacity” [2003] Public Law 592.

Jowell, Jeffrey "Beyond the rule of law: towards constitutional judicial review" [2000] Public Law 671.

Jowell, Jeffrey "Parliamentary sovereignty under the new constitutional hypothesis" [2006] Public Law 562. 
Kyritsis, Dimitrios “Representation and Waldron's Objection to Judicial Review” (2006) 26 Oxford J Legal Stud 733.

McHugh, P G "Tales of Constitutional Origin and Crown Sovereignty in New Zealand" (2002) 52 University of Toronto Law Journal 69.

Mullen, David “The Role for Underlying Constitutional Principles in a Bill of Rights World” [2004] NZ Law Review 9.

Palmer, Matthew "What is New Zealand's constitution and who interprets it? Constitutional realism and the importance of public office-holders" (2006) 17 Public Law Review 133.

Palmer, Matthew "New Zealand Constitutional Culture” (2007) 22 NZULR 564.

Rishworth, Paul "Reflections on the Bill of Rights Act after Quilter v Attorney-General" [1998] NZ Law Review 683.

Rishworth, Paul "Human Rights" [2005] NZ Law Review 87.

Rishworth, Paul "Human Rights” [1999] NZ Law Review 457.

Rishworth, Paul "Human Rights and Bill of Rights” [1996] NZ Law Review 298.

Rishworth, Paul "Applying the New Zealand Bill of Rights Act to Statutes: The Right to a Lawyer in Breath and Blood Alcohol Cases" [1991] NZ Recent Law Review 337.

Rivers, Julian "Proportionality and Variable Intensity of Review" (2006) 65(1) Cambridge Law Journal 174.

Rosenfeld, Michel "Rethinking constitutional ordering in an era of legal and ideological pluralism" 6 Int'1 J. Const. L. 415.

Singh QC, Rabinder “Interpreting Bills of Rights” 29 Statute L Rev 82.

Steenkamp, Anton J "The South African Constitution of 1993 and the Bill of Rights: An Evaluation in Light of International Human Rights Norms” (1995) 17 Human Rights Quarterly 101-126.

Lord Steyn, "Deference: A Tangled Story” (2005) Public Law 346-359.

Sunestein, Cass "Recent Decisions of the United States Court of Appeals for the District of Columbia Circuit” (2005) 73 George Washington Law Review 693.

Walton, Tim “Get it in writing” (5-11 August 2006) New Zealand Listener 26.

Webb, Meredith "Applying the Bill of Rights in the New Zealand Context" (2007) 13 Auckland University Law Review 217.

Wilberg, Hanna "The Bill of Rights and other enactments" (2007) New Zealand Law Journal 112.

Wilberg, Hanna “Judicial Remedies for the Original Breach” [2007] NZ Law Review 713.

Young, Alison L “Hunting Sovereignty: Jackson and Her Majesty’s Attorney-General” (2006) SUM Public Law 187. 